



\section{THE HISTORY AND NATURE of INTERNATIONAL RELATIONS}




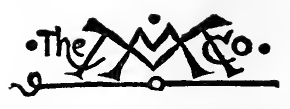

THE MACMILLAN COMPANY NEW YORK - BOSTON - CHICAGO - DALLAS ATLANTA - SAN FRANCISCO

MACMILLAN \& CO., LIMITED LONDON - BOMBAY - CALCUTTA MELBOURNE

THE MACMILLAN CO. OF CANADA, ITD. TORONTO 


\title{
THE HISTORY AND NATURE \\ of \\ INTERNATIONAL RELATIONS
}

\author{
Edited by \\ Edmund A. Walsh, S.J., Ph.D., \\ Regent, School of Foreign Service, \\ Georgetown University
}

Stephen P. Duggan

Michael I. Rostovtseff

Carlton J. H. Hayes

James Brown Scott

James Lawrence Laughlin

\section{Contributors}

John Bassett Moore Esteban Gil Borges Leo S. Rowe Paul S. Reinsch Edwin M. Borchard

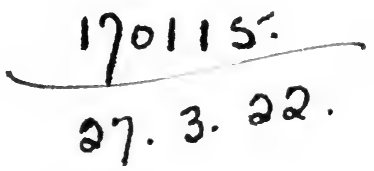

Dirm Yark

THE MACMILLAN COMPANY

1922

All rights reseroed 
PRINTED IN THE UNITED STATES OF AMERICA

Copyright, 1922 ,

By THE MACMILLAN COMPANY

Set up and printed. Published January, 1922. 
To

Constantine E. McGuire, Ph.D.

With respect and appreciation 
Digitized by the Internet Archive in 2007 with funding from Microsoft Corporation 


\section{P REF A C E}

In order to afford the students of the School of Foreign Service of Georgetown University an opportunity to supplement and illustrate their classroom work by a rapid survey of the principal phases in the history of relations between sovereign states from the earliest antiquity down to our own times, the authorities of the School have undertaken to invite, each year, a number of distinguished scholars, each a master in his respective field, to deliver a special course of lectures on international relations. The first fifteen of these lectures articulated into an organic whole and entitled "The History and Nature of International Relations," were delivered in the Auditorium of the National Museum, Washington, D. C., and were open to the general public. The presence, in gratifying numbers, of the general public on alternate Friday evenings during the winter and spring of I920-192I furnished abundant proof of the growing interest now being manifested by thoughtful Americans as well in theories of Political Science as in the actual conduct of our foreign relations.

The present volume reproduces such of the lectures as have been judged likely to prove of permanent value both for students of the School of Foreign Service and for general readers seeking authoritative guidance through the tangled maze of world politics.

Whether or not it is because the centre of political gravity in international affairs is to be found near, if not conterminous with the centre of financial gravity, it is beyond dispute that the Capital of the United States, at the present time, has become the focal point of interest for the civilized world. It was, therefore, never more imperative than at the present juncture to foster scientific study of the principles and practice of international re- 


\section{PREFACE}

lations and even of such preambles of the science of government as a right understanding of the origin of civil society and its first postulate, authority, since foreign policies will naturally be largely influenced by the philosophy underlying the decisions of those who direct the destinies of states.

The gunfire of an irresponsible fanatic at Sarajevo, seven years ago, unloosened elemental forces that not only swept crowns and thrones into the discard but tore the veil of respectability from a certain type of imported philosophy extremely popular in American universities, during the last two generations, but not professed so confidently since August, I9I4. The "scrap-of-paper" solution of embarrassing difficulties arising out of international obligations is a logical through brutally expressed corollary of the metaphysics that would substitute expediency and the pragmatic sanction for the ethical basis of jurisprudence.

It is hoped that the present volume will clear a satisfactory approach to the detailed studies of the various aspects of international relations which this series will present from time to time.

In conclusion, the Editor begs to express to the Regents of the Smithsonian Institution the thanks of the authorities of the School of Foreign Service for the use of the Auditorium of the National Museum; acknowledgment of great indebtedness is likewise made to Dr. Constantine E. McGuire of the Inter-American High Commission for his untiring labors in arranging the details of the course, - to Dr. J. Franklin Jameson, Department of Historical Research of the Carnegie Institution of Washington, for his gracious words of introduction on the occasion of the first lecture, and to Mr. Thomas H. Healy, Secretary of the School of Foreign Service, into whose capable hands was entrusted the important but thankless task of correcting the proofs of this publication.

August 8, 1921.

Edmund A. WALsh 


\section{CONTENTS}

\section{THE FUNDAMENTALS \\ IN A SCIENTIFIC STUDY OF INTERNATIONAL RELATIONS}

by

Stephen P. Duggan, Ph.D.

The College of the City of New York

Director of the Institute of International Relations

1. Nature of Diplomacy .................. 1

2. History of Diplomacy .................. 4

3. The Agents of Diplomacy............... 9

4. Legislative Intervention in the Conduct of International Relations...................... 13

5. Methods of Diplomacy.................... 21

\section{INTERNATIONAL RELATIONS IN THE ANCIENT WORLD}

by

Professor Michael I. Rostovtseff, Ph.D., D.Litt. (Oxon), of the University of Wisconsin, formerly of the University of Petrograd; Member of the Russan Academy of Sciences and Corresponding Member of the British Academy.

1. Source Material and Method of Approach........ 31

2. Ancient and Modern View of War............ 35

3. Means of Preserving Peace in Antiquity. The Balance of Power.................... 37

4. Ancient Treaties..................... 40

5. Religion as an Influence in International Relations 45

6. Peace by Arbitration in the Ancient World....... 49

7. Diplomatic Agents in Antiquity ............. 51

8. Conflict between Right and Force............. 55

9. Period of Constant Flux................. 57

10. The Roman Theory of International Relations.... 61 


\section{CONTENTS}

\section{MEDIEVAL DIPLOMACY}

by

Professo Carlton J. H. Hayes, Ph.D.

of Columbia University

1. The Medieval Heritage................ $\quad 69$

2. Medieval Churchmen and International Law. .... . 74

3. The Truce of God, Chivalry, Papal Ambassadors... 77

4. The Catholic Ideal of Universal Peace......... 81

5. Evolution of Professional Diplomacy.......... 85

\section{DEVELOPMENT OF DIPLOMACY IN MODERN TIMES}

by

Hon. James Brown Scott, A.M., '.U.D., LL.D.

Secretary of the Carnegie Endowment for International Peace

1. Popular Concept of Diplomats and Diplomacy.... 93

2. True Functions of Diplomats and Diplomacy..... 95

3. The Modern State System and the Law of States. . 96

4. The Balance of Power, Its Nature and Application 99

5. The Balance of Power in Modern Times, The Holy

Alliance........................... 107

6. The Content of Modern Diplomacy........... 110

7. Arbitration, Definition and Historical Application. . 112

8. International Conferences-The Ideal of Simon

Bolivar........................... 116

9. The Hague Conferences................ 120

10. The United States as an Exemplification of International Organization.................. 124 


\section{CONTENTS \\ ECONOMIC FACTORS \\ IN INTERNATIONAL RELATIONS \\ by}

Professor James Laurenc Laughlin, Ph.D. (Harvard), Ph D. (honoris causa, Geissen), formerly of the University of Chicago; Director of the Journal of Political Economy.

1. Economics and Politics................... 133

2. Movements of Population................ 135

3. Foreign Trade and Shipping.............. 138

4. Economic Postulates of Foreign Trade........ 141

5. Foreign Exchange................... 145

6. Financial and Industrial Obstacles to International

Peace............................. 148

\section{SPECIFIC AGENCIES FOR THE PROPER CONDUCT \\ OF INTERNATIONAL RELATIONS}

by

Hon. John Bassett Moore, LL.D., Professor at Columbia University; formerly Counsellor of the Department of State; Member of the Permanent Court of The Hague; Vice-President of the Inter-American High Commission; Member of the International Commission of Jurists; President of the Pan-American Society of the United States.

1. Amicable Methods-Negotiations-Good OfficesMediation-Arbitration................ 157

2. Non-Amicable Methods. Non-Forcible, Rupture of Diplomatic Relations. Forcible, Reprisals- $\mathbf{P a}$ cific Blockade, War-Limited War-General War............................ 167 


\section{CONTENTS}

\section{THE EVOLUTION OF INTERNATIONAL PRIVATE LAW \\ by}

The Honorable Esteban Gil Borges, LL.D. (Georgetown)

Minister of Foreign Affairs, Venezuela

1. The Evolution of International Private Law...... 185

\section{LATIN AMERICA AS A FACTOR IN INTERNATIONAL RELATIONS} by

Hon. Leo S. Rowe, Ph.D.,LL.D., Director General of the PanAmerican Union; President of the American Academy of Political and Social Sciences.

1. The Philosophy of American History ......... 203

2. Latin American Ideals-Bolivar.............. 205

3. Sources of Potential-Influence for American States. 208

4. Pan-American Co-operation............... 210

5. The Role of the Americas................. 212

\section{THE FAR EAST AS A \\ FACTOR IN INTERNATIONAL DEVELOPMENTS}

by

Hon. Paul S. Reinsch, Ph.D., LL.D., former Minister of the United States to China

1. China before contact with Western civilization.... 219

2. Present-day China.................... 220

3. Relations between China and Japan during and after the World War...................... 223

4. China, Japan and Siberia................ 225 


\title{
CONTENTS
}

\section{THE UNITED STATES AS A FACTOR IN THE DEVELOPMENT OF INTERNATIONAL RELATIONS}

by

\author{
Professor Edwin M. Borchard, LL.B., Ph.D., \\ of the Law School of Yale University
}

1. The Genesis of American Foreign Policy........ 229

2. Nature of Early American Policy............ 234

3. Monroe Doctrine...................... 235

4. Interpretation of the Monroe Doctrine........ 240

5. Foreign Views on the Monroe Doctrine........ 244

6. Latin America and the Monroe Doctrine........248

7. The Monroe Doctrine and the Far East........ 251

8. Indirect Influence of the United States on World Politics, Neutrality - Recognition - Freedom of the Seas-Minor Doctrines, Contributions and Policies...........................258 Appendix............................ 295 
, 


\section{The Fundamentals in a Scientific Study of International Relations}





\section{THE HISTORY AND NATURE OF INTERNATIONAL RELATIONS}

CHAPTER I.

\section{THE FUNDAMENTALS IN A SCIENTIFIC STUDY OF INTERNATIONAL RELATIONS}

The reputations not only of individuals but also of professions have suffered as a result of the Great War. Probably no profession has fallen more in public esteem than diplomacy. The accusations against the diplomatist range from mere stupidity in not foreseeing what the course of events would be, to deliberate intrigue in bringing about the course of events. Practically every aspect of diplomacy, its aims, methods, policies, and agents have been condemned. No course, therefore, on the History and Nature of International Relations would be complete without an attempt to discover how modern diplomacy originated, of what its essential nature consists, whether its methods are calculated to realize its aims, how far its agents can be held responsible for results and whether its defects are so obvious as to suggest proper methods of reform. It would be futile to try to make an exhaustive analysis of the subject in a single paper. This chapter, therefore, will consider briefly certain elements only which a scientific study should include and the criteria which a serious student should employ.

NATURE OF DIPLOMACY

Diplomacy is "the art of managing the intercourse and adjusting the relations between states by negotiation." It 
is usually studied as the handmaid of international law, but it is in greater conformity to the facts of history to state that international law is the resultant of the working of diplomacy. Were international law to be entirely swept away, diplomacy would still survive, for states must needs have relations with one another. The attitude adopted by one state to another or to others during negotiations is determined primarily by self-interest. It is the duty of the diplomatist always to keep the security and dignity of his state in the forefront of negotiations and to enable it to attain legitimate ambitions by every justifiable means. If a state has a settled national policy in foreign affairs his activities must look to the maintenance of that national policy. During practically the entire nineteenth century, the British government had as the cornerstone of its foreign policy the maintenance of the integrity of the Ottoman Empire. A British diplomat who, however much he might disapprove the actions of the Ottoman government, failed to uphold that policy would have soon been rejected by government, Parliament and people. Similarly no place can be found in the American diplomatic service for an official who neglects to maintain the integrity of the Monroe Doctrine. The diplomatist labors under the consciousness that every foreign diplomat with whom he negotiates, labors with an aim in view similar to his own. The diplomatist works, moreover, in a field where the unforeseen may modify conditions at any moment, but he is nevertheless held responsible for results. $\mathrm{He}$ is not a free agent. If he is a representative of his country abroad, his actions and decisions may be influenced and even determined by telegraphic orders from home, however much against his will. If he is in the Foreign Office at home, he works in the knowledge that he must carry the legislature or its Committee on Foreign Affairs with him when he is part of a parliamentary regime, or carry the Senate with him if he is part of the American system. This may compel him to 
follow a policy and agree to decisions for which he personally has no liking.

"Open diplomacy" is one of the reforms most loudly demanded today. The complaint is made that diplomatists bring negotiations to a conclusion without keeping the public informed or without consulting the representatives of the people who, they say, have little to do with the conduct of foreign policy except to ratify whatever decisions are placed before them. Such criticism neglects to take into consideration the fact that in foreign affairs one country is dealing with matters that do not concern itself alone. It frequently deals with secrets which it must share with other countries. A premature disclosure might result in the breaking off of negotiations altogether by another power, for that other power may follow methods wholly at variance with freedom of discussion and unrestrained publicity. Diplomatic negotiations, moreover, are frequently of a delicate nature, involving national predilections which cannot be overlooked. To attempt to discuss everything in public would often offend national pride, arouse international antagonisms and render impossible the give-and-take so necessary to the successful conclusions of negotiations, for both sides have rights to guard and national points of view to realize. A wise diplomat may render during negotiations the greatest service to the public interest by ignoring popular clamor for full information even when voiced in the legislature. Lord Lyons did much to solve a serious situation when he deliberately and courageously refrained from giving any opinion of his own in the Trent affair.

Then, too, it must not be forgotten that in many cases diplomatic negotiations have to do with subjects a knowledge of whose technical details requires special information or which would have little interest for the general public, or in which many sources of valuable information would dry up entirely were publicity given to them. It 
is certainly true that a ministry which neglects to obtain the support of public opinion whenever possible loses an immense force in securing the adoption of its foreign policy. The real statesman is he who will constantly seek to instruct public opinion in his international policy' so as to carry it with him in time of crisis. Recent events have shown how readily public opinion will respond to the activities of the propagandist in such times. Statesmen and diplomatists are at least partially informed on international affairs. There would be little profit in turning from them to an ill informed public opinion for leadership. Moreover, it is a question whether popular assemblies are more likely to keep the peace than statesmen and diplomatists, especially when laboring under the stress of nationalist excitement. It did not prove so in the United States at the time of the Spanish War. It is a question, therefore, whether even on the grounds of theory, "open diplomacy" in the extreme sense would affect the conduct of international affairs for the better. Finally, as will be considered at greater length later in this chapter, most governmental systems of today afford the representatives of the people fair opportunity if they wish to use it, to see to it that the international relations of the country are carried on not only to advance the national interests but in accordance with good faith and honorable conduct. ${ }^{1}$

\section{II}

\section{HISTORY OF DIPLOMACY}

Diplomacy was originally the servant of war when war was the normal state of international intercourse. It was an agency to secure without fighting the ends for which war was waged. Today the positions are re-

\footnotetext{
${ }^{1}$ No student of diplomacy should fail to study carefully the discussions on publicity in the conduct of foreign policy as found in Hansard's Parliamentary Debates passim and in the Report from the Select Committee on the Diplomatic Service, 1861. The latter is an invaluable statement.
} 
versed, and war, when it takes place, is the outcome of diplomacy. The present status of diplomacy is the result of an evolution in which is discernible a movement away from a condition in which falsehood, chicane, and excessive formalism prevailed in international relations, to one characterized by honorable conduct among the negotiators, and by business methods in procedure. Diplomacy is one of the products of the Renaissance. Intercourse between nations existed, of course, from time immemorial; but diplomacy, as defined in this paper, viz.: "The art of managing the intercourse and adjusting the relations between states by negotiations" dates from the rise of permanent embassies. Feudalism had little place for diplomacy, but the Italy of the thirteenth and fourteenth centuries anticipated, in miniature, Europe of the nineteenth century. Intense rivalry existed between the little states into which northern and central Italy were divided, and for self-preservation alliances and ententes were necessary to maintain the balance of power. This object could not be accomplished by temporary embassies, such as those of the middle ages, which were sent to accomplish some specific purpose and were disbanded immediately afterward. Permanent representatives were necessary who were to be "the eyes and ears" of their states at the foreign courts. Of all these early Italian states Venice had most at stake and it was natural that she should first establish permanent embassies and develop a professional diplomatic class. Her example was followed in course of time not only by all the Italian states but by the national states that slowly developed in western Europe such as Spain, France and England, and by the Empire. The permanent embassy had become the normal agency of international intercourse by the middle of the sixteenth century. But it was looked upon as a necessary evil, the home government trusting its representative abroad none too much and the government to which he was sent viewing him with extreme suspicion. At first, Venetian ambassadors were sent for short terms 
of three or four months, and the term was only gradually lengthened to three years, at which it remained until the Republic was abolished by Napoleon. Moreover, from the very founding of the permanent embassy Venice laid down rules to be followed by its ambassadors abroad and required them to make comprehensive reports to the Senate of their observations and activities. ${ }^{1}$

The suspicion with which foreign ambassadors were viewed at first is well illustrated by the practice of the three great monarchs of the Renaissance, Charles V, Francis I and Henry VIII of interpreting the phrase "ambassador near the court" to keep ambassadors as far as possible away from the court. Nor did these monarchs scruple to open and examine the correspondence of foreign ambassadors. The diplomatist, it must be admitted, had early earned a bad reputation, but it is questionable how justifiably. The prudent suggestions made by Machiavelli in The Prince for the guidance of statesmen accurately reflected the spirit of the times though they frequently were much overstepped in actual practice by ambassadors. Sir Henry Wotton's definition of an ambassador, "an honest man sent to lic abroad for the good of his country" is fairly descriptive of the attitude of his day, that of James I. The Father of International Law, Grotius, ${ }^{2}$ whose great work De Jure Belli ac Pacis was published in 1625, viewed the permanent ambassador with scant sympathy and maintained that he had no right of existence. The growth in the importance of the office, however, is well illustrated by the statement of Vattel whose La Droit des Gens was published in 1758 , that, though there is no obligation on the part of a sovereign to accept a permanent ambassador

${ }^{1}$ The fifteen volumes into which these reports have been collected provide invaluable material for the student who can read Italian and is interested in the history of the states of Western Europe.

'For discussion of Grotius' place in International Law, see Appendix. 
it is necessary as a matter of convenience, comity and custom. ${ }^{1}$

The eighteenth century was the period par excellence when dynastic interests controlled international relations. The ambassador, as the personal representative of the sovereign, occupied a place in the affairs of the day second only in importance to that of the sovereign himself. The ceremoniousness emphasized in official life by Louis XIV, and copied from Versailles throughout Europe, demanded certain qualities in an ambassador such as smooth and attractive manners, shrewdness and the art of using personal influence in managing men. As these could be acquired best at court, the practice arose of young men of rank becoming attached to embassies for the express purpose of learning the art of diplomacy. Diplomacy became an aristocratic profession. At the same time it became a hierarchial profession. Down almost to the sixteenth century no distinction of rank existed among the diplomatic representatives at a court though various titles were used in referring to them. But the desire of the rulers of big states to be differentiated from those of little states caused a distinction between Ambassador and Resident to develop during that century. The process of differentiation determined not by questions of function but of dignity continued down to the Congress of Vienna of 1815, when regulations were adopted which were confirmed at the Congress of Aix-la-Chapelle of 1818 dividing diplomatic agents into four classes:

(I) Ambassadors, legates, nuncios.

(2) Envoys extraordinary and ministers plenipotentiary.

(3) Ministers Resident accredited to the sovereign.

${ }^{1}$ To understand the real status of the ambassador at the beginning of the eighteenth century, the student of diplomacy should study Callieres De la Manière de negocier avec les souverains, published in 1716 and which still remains authoritative in its field. 


\section{(4) Chargés d'affaires accredited to the Foreign office. ${ }^{1}$}

As these ranks have only ceremonial value, and do not affect either the functions or powers of diplomatic representatives, the United States ignored them and accredited all its principal diplomatic agents as ministers plenipotentiary, i. e., ministers of full power and authority. In I893, however, Congress enacted legislation whose practical effect was to authorize the President to conform to the practice which prevailed among other nations. During the nineteenth century the heartburnings formerly caused by the question of precedence among diplomatic agents were extinguished by the simple rule of seniority of appointment and in the case of signatures to treaties by an appeal to the alphabet.

The French Revolution with its emphasis upon the political principles of nationality and democracy had a profound influence upon the qualities demanded of a diplomatist. The ambassador no longer represents a sovereign to a sovereign but a nation to a nation. Moreover, the nineteenth century has been one of great international congresses in which the duty of considering the common interests of Europe or of the world has become a function of diplomacy. A knowledge of history, geography, international law and political psychology became of greater importance in the ambassador than the personal qualities of suavity and astuteness, though these are by no means negligible even now. Again, the Industrial Revolution, emphasizing the place of the economic element in the affairs of men, has resulted in the need in the diplomatist of today of a knowledge of such subjects as the laws and conditions of trade and the general principles of international finance. It must not be overlooked that the commercial purposes of diplomacy tend constantly to become more

\footnotetext{
${ }^{1}$ The duties, privileges and functions of these diplomatic agents are discussed somewhat in detail in chapter beginning on page 157.
} 
prominent. These qualities demanded by modern conditions were seldom to be secured by the choice of a diplomatic agent dictated by favoritism or politics. Hence in nearly all the great countries of the world the management of international intercourse has passed into the hands of a trained diplomatic class. At first the method of training was that of apprenticeship, but this gave way later to university preparation followed by examination. No nation compares with France in the facilities of preparation for the diplomatic career. The Ecole Libre des Science politiques with its array of courses in history, geography, politics, economics, international law and history of diplomacy and with its eminent teachers drawn from the courts, the government service, and practical life as well as from the university provides today at least eighty per cent of those who enter the French diplomatic service. In this development, the United States, chiefly because of the comparative simplicity of its foreign relations in the past, has lagged behind the other great nations. But her immense commercial expansion and her participation in the solution of the intricate international problems that face the statesman of today will compel her to adopt the reform of her diplomatic service if she is properly to look after the security, the dignity and the interests of the nation. ${ }^{1}$

\section{III}

\section{THE AGENTS OF DIPLOMACY}

The conduct of the international relations of a country is essentially an executive function. Historically,

\footnotetext{
${ }^{2}$ For the further consideration of the history of diplomacy the student is referred to Henry Wheaton, History of the Laze of Nations in Europe and America, 1845; Debidour, Historie diplomatique de lEurope contemporaine 1814-1914; J. B. Moore, American Diplomacy, 1905 ; D. J. Hill, History of European Diplomacy, 1905; and J. W. Foster, The Practice of Diplomacy, 1906.
} 
the monarch was the state and when his powers were gradually distributed among the organs of government the duty of speaking and acting for the state naturally remained with the executive. Few will deny that legislatures are unsuited to originate and determine the foreign policy of a country and conduct delicate negotiations, which are of necessity often complicated and where the issues involved may be momentous. In no constitutional country; however, is the executive power irresponsible in international relations. It is everywhere subject to the intervention of the legislative power, though the method of intervention differs. This control, however, extends to particular questions of foreign affairs rather than to foreign policy generally. In the United States each administration pursues policies without any legislative control whatever unless the policies require the passage of treaties or laws. For example, the Taft administration encouraged the financial consortium in China. The Wilson administration discouraged it. And in the countries organized upon the parliamentary system, while the legislative control is more direct, it rarely attempts to interfere with policy.

Under modern conditions the chief agencies acting for the executive in the conduct of international relations are:

( I) The Department of State or Ministry of Foreign Affairs.

(2) Regular diplomatic agents of various grades ranging from ambassadors to chargés d'affaires.

(3) Occasional or special agents appointed to realize some particular object.

For the purposes of this paper they need but a very brief discussion.

(A) The Department of State or Ministry of Foreign Affairs. The public law of every state, whether 
written or customary, provides for a Ministry of Foreign Affairs or a Department of State composed of a trained body of permanent officials headed by a member of the cabinet whose duty it is to handle the international relations of the country. As early as the sixteenth century most of the European monarchies had established a special branch of the government for the conduct of foreign affairs, and the office has steadily grown in influence and dignity. Though the powers of the Minister for Foreign Affairs vary according to the political organization of different states, he is nearly everywhere the regular intermediary between his country and foreign countries from whom all directions and communications to foreign states emanate and by whom all directions and communications from foreign states are received. In Great Britain, for example, neither the sovereign nor parliament can give orders directly to diplomatic agents.

(B) Regular Diplomatic Agents Abroad. Since the status of ambassadors and subordinate diplomatic agents has already been discussed, only their relations with the chief of the foreign office need to be considered here. Before the invention of the telegraph, the position of ambassador was undoubtedly one of greater responsibility than today. A great deal was left to his discretion and good judgment because by the time instructions were received from home conditions might so have changed as to render them out of date. Frequently he had to act upon his own initiative when a difficult question arose. Today he can receive telegraphic directions from home. The result has been to enable the Minister of Foreign Affairs to have a more immediate control of negotiations than formerly. Probably the conduct of Foreign Affairs has thereby become more steady and reliable. And yet it is a question whether the opinion of the man at the distant post, familiar not only with the facts but with the psychology surrounding the problem, is not as important today as 
ever. Official correspondence which must be published has become formal. For example, it is now the general practice for diplomatic agents abroad to repeat conversations with foreign ministers of state without comment. But there is much unofficial correspondence of an intimate nature between the agent abroad and the minister at home, a correspondence moreover which usually remains private. The importance, therefore, to the student of diplomacy of a study of the memoirs of statesmen and diplomatists is obvious. Telegraphic communication has obviated the necessity of the long and detailed instructions that were formerly given to diplomatic agents abroad. One of the unfortunate incidental results for the student was the discontinuance of such collections as that mine of information the French Recueil des Instructions données aux Ambassadeurs et Ministers de France depuis les Traités de Westphalie jusqu'à la Revolution Française.

(C) Occasional or Special Diplomatic Agents. During the seventeenth and eighteenth centuries, monarchs frequently sent secret agents abroad, sometimes to realize a particular object, sometimes to report on conditions without the knowledge of the regular representative. That the latter practice had not completely disappeared even in our own day was made evident in the Lichnowsky revelations. Experience justifies the belief that the practice can hardly fail to affect the diplomacy of the country unfavorably, making it uncertain and personal. When a special agent is appointed today for a particular object, he is usually an expert such as may be needed to negotiate a treaty of commerce or regulate a boundary dispute or other matter outside the scope of the regular diplomatic representative. When a special embassy has a merely ceremonial character, it may result in the increase of international good-will. When it is of a political nature, the speculation and even suspicion that are roused may render such a result dubious. A special agent of a political nature is likely also to 
rouse resentment among the members of the permanent embassy. ${ }^{1}$

\section{IV}

LEGISLATIVE INTERVENTION IN THE CONDUCT OF INTERNATIONAL RELATIONS

The student of international relations must not overlook the fact that the problem of control is one of constitutional law and that his study, therefore, must deal with the internal structure of the state as well as its external activities. This is particularly important in considering what is vaguely called "secret diplomacy", a term which is variously defined but by which the impression is generally conveyed that the nation may be committed to policies or decisions by statesmen or diplomatists without the knowledge of its representatives. The justification of the charge can readily be tested by a brief consideration of the constitutional prescriptions for the conduct of international relations as found in the chief states of the world.

France-The French constitution in Article VIII provides that "the President of the Republic shall negotiate and ratify treaties with foreign countries and communicate their contents to the two Houses as soon as it is compatible with a due regard to the security and interests of the state. Treaties of peace and commerce, treaties which affect the finances of the state, the status of persons and the rights of property of French citizens abroad, are only binding after they have been approved by a vote of the two Houses. No cession, exchange or acquisition of territory may take place without a law being passed to authorize it".

${ }^{1}$ The whole ground covered thus far in this chapter is fully treated in Le Guide Diplomatique, Martens (Charles de) which has been the standard work. It is to some extent superseded by $A$ Guide to Diplomatic Practice, Satow (Sir Ernest) 1917; an excellent summary of the subject is made in Diplomacy and the Study of International Relations, Heatley, (D. P.), 1919. 
Parliamentary control over the conduct of international relations is vested primarily in the Foreign Affairs Committee of the Chamber of Deputies which reports to the Chamber on all questions which are submitted to it. It can demand that the Minister of Foreign Affairs refer to it whatever papers or persons it wishes to examine. Should the Minister decline to accede to its request on account of reasons of State, the Committee usually acquiesces in his view. If the Committee, however, persists in its demand, the matter is brought before the Chamber and if the Chamber supports the Committee, the almost inevitable result is that the Ministry of the day resigns.

The second element of legislative control resides in the privilege of interpellation respecting foreign affairs on the part of individual deputies who usually speak in the name of some political group. The Minister of Foreign Affairs may answer at once or he may request the Chamber to postpone consideration to a later date or to join the question to others of which notice has been given so as to form a general debate on foreign policy. These interpellations and general debates afford excellent opportunity for the instruction of public opinion.

The third element of legislative control resides in the General Budget Committee of the Chamber, the most important and powerful of all the legislative committees which passes upon the budget for foreign affairs. It seldom rejects it. The Budget Committee, moreover, publishes at the end of every year a report on foreign affairs which is a valuable record of French policy. The report is usually written in a sympathetic and explanatory tone. In fact, because of the delicate and complicated nature of European diplomacy and the unusual need in France of considering the security of the State above all things, there has been little desire or attempt on the part of the Chamber of Deputies to exert control over foreign policy. This has been even more true of the Senate which has no permanent com- 
mittee on foreign affairs. Bills submitted to the Senate concerning international relations are referred to a special committee or when the matter is pressing, to the Senate Finance Committee. The French system obtains in most of the countries of continental Europe.

Germany-The Imperial German constitution in Article II provided that "the Emperor shall represent the Empire among nations, declare war and conclude peace in the name of the same, enter into alliances and other conventions with foreign countries, accredit and receive ambassadors." Elsewhere it was provided "that the Chancellor of the Empire, who shall be appointed by the Emperor, shall be chairman of the Federal Council, and shall conduct its business. . . . The commands and demands of the Emperor . . . shall require for their validity the signature of the Chancellor, who thereby assumes the responsibility."

Evidently under the imperial regime in Germany the conduct of international relations was an attribute of the Chancellor and his responsibility respecting them was to the organ of government which gave him his authority. What that organ was was debatable. The Minister of Foreign Affairs was merely the subordinate of the Chancellor. What legislative control of internation relations was there, if any?

Article VIII of the Constitution provided "there shall be appointed in the Federal Council a Committee on Foreign Affairs over which Bavaria shall preside, to be composed of the plenipotentiaries of the kingdoms of Bavaria, Saxony, and Wurtenburg and of two plenipotentiaries of other states of the Empire, who shall be elected annually by the Federal Council." This committee existed solely for the purpose of receiving information on foreign affairs which was usually given by the Imperial Chancellor himself and for providing means for an exchange of views. It had no control, exerted little influence, and between 1871 and 1908 met but twice. As a result of Emperor William's celebrated 
interview on the international situation in 1908 which was published in the London Telegraph and which caused a demand in Germany that he refrain from such disclosures in the future, it became the practice of $\mathrm{Ba}$ varia to call meetings of the committee in connection with any foreign question of great magnitude and lasting public interest.

Almost as slight was the Reichstag's control in international relations. It had no committee on Foreign Affairs. In practice it could deal with questions of foreign policy first by means of interpellations. When an interpellation signed by thirty members was reached on the order of the day, the President of the Reichstag asked the Chancellor "whether and when" he would answer the interpellation. If the Chancellor consented to answer, the interpellator presented his views, the Chancellor or his representative replied and a debate followed if desired by at least fifty members. But, previous to I9I3, motions on the subject of the interpellation were not permitted. In fact, the knowledge that the Chancellor or his representative would not participate in the debate on a critical motion, and that, even if the motion were carried it would be merely an academic expression of opinion, was an effective check to the presentation of such a motion. Few such motions or interpellations were made in practice.

The other method of exercising legislative control of international relations was by means of the Budget Committee of the Reichstag to which the estimates for the Ministry of Foreign Affairs were submitted. The Committee had not the right, however, to send for persons, papers or records, but it could and often did request the President of the Reichstag to do so. Confidential communications were made to it at the discretion of the Chancellor. The proceedings of the Committee were secret but a verbal report was made to the Reichstag and there frequently followed considerable debate. 
It is obvious that, under the Empire, the German constitution provided but slight opportunity for legislative intervention in the conduct of international relations by the executive and that in practice little interference took place. The Constitution of the new German Commonwealth gives much greater opportunity for legislative control. Article 45 reads, "The National President represents the Commonwealth in matters of international laze. He concludes in the name of the Commonwealth alliances and other treatics with foreign powers. He accredits and receives ambassadors." Article 35 reads, "The National Assembly appoints a Standing Committee on Foreign Affairs which may also act outside of the sittings of the National Assembly, and after its expiration or dissolution until a new National Assembly convenes. Its sittings are not public, unless the Committee by a two-thirds vote othcrwise provides." No provision is made for a similar committee in the National Council, which supersedes the Bundesrat of the Imperial regime. The resemblance to the American system of control is obvious, but it is too soon to pass judgment upon the actual working of the German republican system.

Great Britain-According to the public law of Great Britain, the whole conduct of international relations is vested in the Crown. The Ministry which acts in the name of the Crown and assumes responsibility for its acts depends for its tenure upon maintaining a majority in the House of Commons. Its control over foreign affairs is, therefore, responsible in form and has become in practice more and more prudent. Parliament has no committee on Foreign Affairs and its intervention in international relations is made first through interpellations. These are answered in person by the Secretary of State for Foreign Affairs or by an Under-Secretary, usually with considerable frankness. The plea on the part of the Foreign Secretary that fuller information would not be for the best interests of the State 
is generally accepted. An adverse vote would mean the resignation of the ministry in accordance with the principle of collective responsibility. The other method for legislative intervention in international relations is through the voting of the foreign office budget when international commitments may come under discussion. Before the war these discussions were not keen and Sir Edward Grey probably spoke wisely when he said on the occasion of one such debate "As long as the House of Commons remains without some great measure of devolution, its business will be so congested that, with the best will in the world, the House would never be able to acquire that control of imperial policy which it can only acquire by frequent debates on important subjects." In proof of this, one responsible writer has calculated that in the first decade of the nineteenth century 26 per cent of the debates in the House of Commons were devoted to foreign relations, whereas in the last decade but one, the per cent was but eleven. ${ }^{1}$

Apparently the House of Commons itself believes that it can exercise effective control over the conduct of international relations by the ordinary processes of legislation, for in March, I9I8, after public opinion had been much roused over the disclosures of the secret treaties, it voted down the following motion: "That, in the opinion of this House, a Standing Committee of Foreign Affairs should be appointed, representative of all parties and groups in the House, in order that a regular channel of communication may be established between the Foreign Secretary and the House of Commons, which will afford him frequent opportunities of giving information on questions of foreign policy and which, by allowing members to acquaint themselves more fully with current international problems, will enable this House to exercise closer supervision over the general conduct of Foreign Affairs".

${ }^{1}$ Thomas A. Spaulding, Federation and Empire. 
The United States-The Constitution of the United States provides Art. II, Sec. 2, Par. 2, that the President "Shall have power, by and with the advice and consent of the Senate, to make treaties, provided twothirds of the Senators present concur; and he shall nominate and by and with the advice and consent of the Senate, shall appoint ambassadors, other public ministers and consuls." No other reference to the conduct of international relations appears in the Constitution. In 1789 there was established by law the Department of State whose functions were and still are to correspond with and to instruct diplomatic and consular agents abroad and to negotiate with the agents of foreign countries in the United States "or to such other matters respecting foreign affairs as the President of the United States shall assign to the said department". In the United States, therefore, the conduct of international relations with the exception of treaties, is given to the executive. What methods of control reside in the legislature?

The outstanding differences between the parliamentary system of government and the American is that the President of the United States holds office for a fixed period by direct commission from the people irrespective of the legislature while under the parliamentary system the executive, i. e., the ministry, must retain the confidence of the legislature or be voted out of office. In the American system, a cabinet officer is not and cannot be a member either of the Senate or the House of Representatives. It follows that the Secretary of State cannot be interpellated in Congress on questions of foreign policy. His only connection with either House is through the Committee of that House which deals with international relations, the Senate Committee on Foreign Relations and the House Committee on Foreign Affairs, of which two the former is by far the more important and influential. Each House in practice depends on the judgment of its Committee and as 
a rule votes its recommendations. Either committee can request and the Senate committee sometimes does request the appearance of the Secretary of State before it for information but cannot compel his appearance, though he seldom refuses to appear.

The President transmits pro forma to the Senate many papers as "Executive Documents" because they concern international matters that should constitutionally come before it., Either House may call upon the President for other papers or for information which the Secretary of State transmits "if not incompatible with public interest." Such requests frequently meet with refusal. This does not prevent Congress from debating the subject should it not agree with the executive view of the public interest, but its ignorance may cause it to hesitate to act, as in the case with Mexico during the last administration. In fact, except where an executive policy in international relations necessitates the voting of monies by Congress, there is no way of stopping the President in his course of action until the end of his term, except of course by the extreme method of impeachment, which is very hard to apply in practice. Today few will differ from Mr. Bryce in the judgment he expresses in his "American Commonwealth," viz. :

"In all free countries it is most difficult to define the respective spheres of the legislature and executive in foreign affairs, for while publicity and parliamentary control are needed to protect the people, promptitude and secrecy are the conditions of diplomatic success. Practically, however, and for the pur poses of ordinary business, the President is indepenclent of the House, while the Senate, though it can prevent his settling anything, cannot keep him from unsettling everything. He, or rather his Secretary of State, for the president has rarely leisure to give close or continuous attention to foreign policy, retains an unfettered initiative by means of which he 
may embroil the country abroad or excite passion at home."1

This brief summary of the power of legislatures in constitutional countries to intervene in the conduct of foreign affairs by the executive, makes it fairly clear that if the legislature wishes to use its powers, it can prevent the final disposition of an international question in a manner contrary to the legislative will. In parliamentary countries this can be done promptly, in the United States it may require prolonged delay. Similarly, it may be asserted that opportunity exists for the members of the legislature to be fairly well acquainted with the conduct of negotiations. In parliamentary countries particularly the desire and the need of the ministry to win the support of the legislature make it anxious to respond as frankly to legislative inquiries as the interests of the nation permit. The fact is that until the outbreak of the Great War the majority of the members of national legislatures were absorbed in the consideration of pressing domestic problems and had but slight interest in foreign affairs. This was particularly true of the more democratic states. It is reasonable to expect that they will be more interested in the future, and it is to be hoped that the press and the public will be also. The statements issued by the State Department, the publication in the newspapers of important documents and the summaries of the debates in the Senate on international questions are sufficient to enable an intelligent citizen to form his opinion upon it if he is interested. Few hitherto have been interested.

\section{$\mathrm{V}$ \\ METHODS OF DIPLOMACY}

There are manifold methods of diplomatic action,

${ }^{1}$ The most illuminating discussion of this whole subject is found in Parliamentary Papers for 1912, "Treatment of International Questions by Parliaments in European Countries, the United States and Japan," from which I have freely drawn. 
the most important being the negotiation of treaties and other forms of international engagements, the arbitration of controversies that cannot be settled by negotiations, and the summoning of international conferences or general congresses. The nature of the problem that has arisen and the magnitude of the interests involved determine the method that will be employed in any particular case. The limits of this paper will permit of but a brief review of certain aspects of the subject which the student of international relations cannot overlook. ${ }^{1}$

(A) Treaties. Treaties are in the nature of contracts between states. Unless accepted by substantially all states, certainly by all the first-class powers, they are not international law and their "sanctity," therefore, is simply the sanctity of a contract. Because, however, of the importance of the interests involved in the relations between states, the violation of a treaty is regarded as a flagrant breach of customary international law. Probably at least ninety per cent of treaties are of a non-political character dealing with practical problems that arise in international intercourse and seldom causing international friction of a pronounced kind. Political treaties embody the policy of the state, i. e., the attitude adopted by the state in its international relar tions to secure its own welfare primarily. Political treaties are the expression of that attitude as suggested or permitted by the conditions existing at the time of their signature. They are the chief determinants of the reciprocal rights and obligations of states, and disputes arising from them are generally the result of changed political conditions.

In some states where the constitution provides that treaties must be submitted to the legislature for approval, a phrase is added that the submission shall be made as soon as it is compatible with a due regard to the

${ }^{1}$ These methods form the subject matter of the detailed study contributed by Professor John Bassett Moore, pp. 157. 
security and interests of the state. This not only gives opportunity for the negotiation of "secret treaties" but for legalizing and regularizing them. It is, indeed, a question how secret a secret treaty is. A secret treaty between two or more states is usually directed against a third party and that third party has every reason for trying to discover its character. The history of the past fifty years shows that the opportunities for making that discovery are so numerous that the secret treaty is at best only semi-secret. The general character of both the Triple Alliance and the Dual Alliance was known long before the Great War. The evil of the secret treaty is not that its aim and even its contents in a general way may not be known, but that the states against which it is directed cannot be certain how much they know. And since such a secret treaty is almost sure to generate a secret reply, the reply is likely to be more drastic in its provisions than the original. Thus international relations are made worse than ever. To sweep away the evil, it has been frequently suggested that the principle be established in public law that secret treaties are void, and Article XVIII of the Covenant of the League of Nations was directed to that end. The most practicable way of abolishing secret treaties is by amendment of the constitutions of those states which permit them. The prospect of such a reform does not seem any too bright at present.

(B) Arbitration. When a matter in dispute between nations cannot be adjusted by direct negotiation, it may be referred to arbitrators agreed upon by the parties to the controversy or to the permanent tribunal of arbitration erected by the Hague Conference. Arbitration will naturally receive but a passing reference in a paper on diplomacy as it is essentially judicial in character being diplomatic only in origin. Progress in the means of transportation and communication has immensely increased the intimacy of the intercourse between nations and has caused the loss involved in war 
to be appalling and widespread. The nineteenth century, therefore, has witnessed the growth of a tendency. to employ arbitration as the most economical and enduring method for the settlement of international controversies. During the nineteenth century there were more than one hundred and thirty important arbitrations and though the United States Senate did not ratify the arbitration treaties referred to it in 1904 for the submission of judicial disputes and disputes relating to the interpretation of treaties to the Hague Tribunal, it has, nevertheless, led the way in the employment of arbitration.

The rejection of the Covenant of the League of $\mathrm{Na}$ tions by the United States and the lack of respect for some of its political provisions manifested by some states that have accepted it are fairly good evidence that the world is not yet ready for an international system in which there is even a suspicion that the independence, security, interests or dignity of the individual State is subject to control or supervision by any external influence. The recent catastrophe, however, has generated a horror of war among all civilized nations as a means of settling international dispute and it may, therefore, reasonably be expected that arbitration which is volumtary in its nature and which avoids the objections against both international control and war will be viewed with increasing deference in the years to come. The rejection by the League of Nations of any extension of the principle of voluntary arbitration in its committee's report on the establishment of a Permanent Court of International Justice is indicative of the existence of a determined opposition to the obligatory principle.

(C) International Congresses and Conferences. A third method of diplomatic action is the general congress or conference which may assemble to settle questions which vitally affect several states or involve the peace of a continent or of the world. The international congress is partially the result of the existence of the 
principle known as the Balance of Power which has been the most potent single factor in the development of diplomacy. As a basis of action the principle had its origin in the sixteenth century and was a result of the rivalry of the House of Austria and the Kings of France. The Thirty Years' War in which that rivalry played a prominent part eventuated in the first European congresses, those of Münster and Osnabrück, which had produced the Peace of Westphalia of 1648 . Those congresses formed a precedent which has been freely followed. From the beginning of its history the Balance of Power has had for its object the maintenance of the independence and the security of all states by organizing alliances to prevent any one state or group of states being able to dominate and prescribe the law to all others. Since the close of the seventeenth century, Great Britain has been the foremost champion of the principle. However much the principle may be condemned, it is in its essence a mere timely provision against a probable danger and it would be unwise to assume that it has been superseded. Unless the League of Nations include all the great states of the world and unless its principles secure more hearty adherence in their application from the states which have become members, there is no reason to suppose that the conditions that necessitated the Balance of Power in the past will not exist in the future.

The conflict against Napoleon had as one result the recognition that Europe had common interests and the series of congresses that followed his fall had as an outcome the system known as the "Concert of Europe" wherein the independence of the individual state has been, in certain matters, subordinated to the general welfare of Europe as a whole. It would be easy, no doubt, to exaggerate the effective influence of this system, but there can be no doubt that the recognition that a controversy was a European question to be settled by "Europe" made for peace. "Europe" in this connec- 
tion meant the Great Powers whose diplomats when they assembled in a European congress understood functions that were both legislative and administrative in character. It has been customary for a congress to record in its protocols the principles upon which its conclusions were based, and to invite nations not represented at the congress to adhere to the results of its deliberations. It is obvious, therefore, what a great influence upon the spirit and practice of diplomacy the Concert of Europe has had. As long as it functioned, it maintained peace and it laid the foundations for an international organization which extends beyond the confines of Europe. $^{1}$

\section{CONCLUSION.}

In the study of no subject dealing with human affairs does the student need a greater equipment of knowledge, discernment, imagination and impartial judgment than in the study of diplomacy. He must remember that diplomacy deals with the relations between nations, and, to understand the reasons either for the general policy pursued by a nation over a long space of time or for its attitude in a particular international situation, he must know its constitution, the actual working of its government and the relative strength of the political parties in it, the national aims, the national temperament, and the dominant personalities. In the study of any particular problem he must try to have access to all the sources on every side and

${ }^{1}$ The materials for the study of this caption are very numerous. The collections of treaties and treaty documents, of which there are many, are of first importance. Koch et Schöll, Historie abregée des Traités (from 1648 to 1815) is of value. The standard work is Martens (G. F. de) Recueil des principaux traités de paix, d'alliance - . . depuis 1761 iusau'à nos jours (1808), which has been brought down to our day. Of the very highest value is Hertslet (Edward) The Map of Europe by Treaty since 1814. This is an invaluable work for the student. Moore (J. B.) A Digest of International Law is an exhaustive digest of the international practice of the United States from its origin up to 1906, which should be constantly consulted by the student. The same author's International Arbitrations is the standard work on the subject. 
carefully compare them, if he is to approximate the truth. Moreover, he must understand that despatches and official documents never tell the whole story and that, however illuminating the speeches and writings of the day may be to give an understanding of the psychology of the people and their leaders, they will not explain what has been intentionally omitted in official documents. Those must be sought for in the biographies, memoirs, diaries, and private letters of statesmen and diplomatists and others who were in position to know. And even then much must be left to the inductive imagination.

The student thus equipped is prepared to engage intelligently in the study of a wonderful and magnificent drama. All the instincts and passions of the individual are in action on a grand scale in the intercourse between nations. The student will probably learn to admire the accomplishment of diplomacy rather than to condemn its failure. And he will, no doubt, conclude that as human nature, with its mixture of what is instructive and what is rational, of what is constructive and what is destructive, is the one constant factor in international relations as it is in life generally, so diplomacy will ever continue an essential element in the intercourse between states whatever world organization may be adopted, just as compromises will ever be necessary in the daily relations of individuals under whatever system of morals and religion they may live. 



\section{International Relations in the Ancient World}





\section{CHAPTER II.}

\section{INTERNATIONAL RELATIONS IN THE ANCIENT WORLD}

I

\section{SOURCE, MATERIAL AND METHOD OF APPROACH}

No exhaustive treatment of international relations in the ancient world exists in scientific literature. The two volumes devoted to this subject by Coleman Philippson ${ }^{1}$ are written by an excellent lawyer, a good specialist in modern international law, but a dilettante in the domain of ancient history. On the other hand, many special investigations written by classical scholars chiefly on the subject of international treaties and interstatal arbitration, although exhaustive and sufficient in regard to the special subject in question, do not cover the whole field of international relations and are silent on many important general questions. I refer to the recent works of Marcus Niebuhr Tod and A. Raeder on arbitration and to the book of Taubler on Roman treaties. ${ }^{2}$ I cannot myself give in these two short papers a full account of all the important and complicated questions connected with the main problem of the system of international relations in the ancient world, but I should like to insist on some fundamental points which unfortunately have been generally mistreated and misinterpreted. My point of view is that of a historian, and as such I insist on the treat-

\footnotetext{
${ }^{1}$ The International Law and Custom of Ancient Greece and Rome, London, Macmillan, 1911.

${ }^{2}$ Marcus Niebuhr Tod, International Arbitration Among the Greeks Oxford, 1913; A. Raeder, L'Arbitrage International chez Les Hellenes, 1912 ; E. Täubler, Turferinne Romanum, Studia zur Entwicklungsgeschicte des römer Reiches, I Die Staatsverträge und Vertrags Verhältnisse; Berlin-Leipzig, Teubner, 1913.
} 
ment of this question from the historical point of view without modernization, but, at the same time, without the tendency to consider the ancient world as an epoch totally different from our own period and important for a historian only as a matter of historical curiosity.

The first question one may put to me is-why should we begin the history of international relations with the socalled classical epoch, and not with the so-called middle ages, when the system of European states, totally different from the system of states which prevailed during the classical period, was formed? I think the question itself implies a misinterpretation of historical facts. The system of the modern European States is in no way a creation of the so-called middle ages. Most of the modern European States are nothing but a development of the provinces of the Roman Empire. The natural frontiers of Spain, France, Italy, even Britain of today are the ancient frontiers of Italy and the western Roman provinces during the Roman Empire. Modern Germany covers the territory of the Roman province, Germania, as it was planned by the genius of Caesar and Augustus. Austrian territory before the war coincided with the boundaries of the Roman Danube provinces. On the other hand the foundations of civilized life in modern Europe were laid during the classical period and the type of our European and American mentality was inherited by us from our classical predecessors.

Thus, if we try to understand one or the other of our fundamental institutions, or if we endeavor to explain the most important features of our political, economic, social and intellectual life, we are bound to go back to the main sources, i. e., to the achievements of our classical predecessors.

International relations and the main ideas which form the substance of our international law present no exception to this general rule. I affirm that the type of our international relations, the different tendencies existing in this domain and the most important moral and legal ideas 
which form the basis of our international law formed the foundation of the international relations of the ancient world as well. I cannot discover any capital difference. Modern Europe moves on the same lines on which the ancient world moved for centuries. I do not believe I am exaggerating. I will endeavor to prove this statement in this paper, from the historical as well as the systematic point of view. But please do not misinterpret my words. Some of the institutions and ideas I speak of were fully developed in the ancient world. Others may be traced at their very beginning only, and it was the destiny of later epochs to develop them more fully.

Now the question why some of these institutions and ideas developed, while others did not, is of the greatest historical importance. If we know the causes of the florescence of some institutions and of the comparative debility of others we may judge, perhaps, of the future of our own similar institutions and distinguish the conditions under which they are growing or decaying. For, our own modern world is still in the process of its ascendant movement; we see no signs of arrest or decay. The ancient world also had its time of uninterrupted progress which lasted many thousands of years. But the ancient world accomplished its circle of evolution and experienced a period of deep decay, a period of return to very primitive conditions. And it is highly instructive to see which institutions among those with which we are concerned in studying international relations have survived and which died out completely or remained as mere survivals, and finally, though not least important, it is desirable to know the causes of this phenomenon.

As I have already pointed out, the most important defect of existing attempts to build up a history of international relations is the almost complete lack of historical method in dealing with this question. Most of the general studies of the history of international law treat the ancient period as a whole and oppose it directly to 
our modern ideas and institutions. I am not an enemy of systematic treatment nor of the comparative method in the investigation of juridical and political institutions. But I feel that we have a right to require a correct and fair use of this method. If one uses the antithesis, "ancient and modern", I have the full right to ask, "What epoch in the evolution of the ancient world does he mean and what time in the evolution of our modern world?" For in the history of the oriental monarchies, to cite one instance, we have different epochs, as, e. g., the epoch of the great Pharaohs of the XVIII dynasty in Egypt (II Millennium), and the epoch of the first five dynasties (IV Millennium) which differ, one from the other, as much as the Merovingian epoch differs from the reign of Louis XIV in the history of the French monarchy. In the history of the Greek States, the period of the Ionian colonization, the period of full florescence of Athens in the $\mathrm{V}$ and IV centuries, and the period of the Hellenistic Monarchies, present the same enormous differences as, in the history of America, do the period of colonization, that of the civil war and that of President Wilson, although throughout the history of the Greek States the general political structure of the city-state remains almost unchanged. Again, contrast Rome of the early republic with Rome of the time of Cicero and Rome ruled by the emperors! There is the same people, and there are the same names for many institutions, but how enormous are the differences! In the history of Germany, the period of Arminius, that of Frederick the Great and that of the last Hohenzollern exhibit striking dissimilarities.

Hence it is that we must be very careful in our comparisons between the ancient and the modern world. We must not forget that the modern world started from quite different conditions from those prevailing in the ancient world. The modern world inherited from the ancient a large stock of ideas and institutions which helped it to build up its culture on firm and advanced ground. 


\section{II}

THE ANCIENT AND MODERN VIEW OF WAR

Let me bring forward one example which will lead us directly into our own subject, "in medias res". The fundamental conceptions of international relations in the ancient and in the modern world are utterly different. The modern world considers the natural condition of life in our society to be the state of peace. War is nothing but a temporary suspending of this natural condition and is regarded as an abnormal state. Free intercourse between different nations is normal; restrictions and limitations of the rights of foreigners are abnormal and require serious reasons. Such, briefly, are our ideas as they developed during centuries of existence of the family of European nations. But in the ancient world, generally, the natural attitude of one state towards another was that of potential and actual enmity. Hence, war, not peace, was the foundation of international relations. To quote one of the most authoritative writers on this subject: "In the ancient world the foreigner, from the political point of view, is an enemy. The individual, as zeell as a state, comes out of these conditions of natural hostility only by means of a juridical act, a treaty which makes possible for the citizens a free intercourse with another state." (Taubler, opus cited, p. 1.)

What are the causes of this fundamental difference? Have we to assume that ideas regarding peace and war were totally different in the ancient and the modern world? Can we affirm that the ancients did not look on peace as a desirable thing, and as a good in itself? Was the ancient psychology totally different from our own? By no means. Like the modern world, ancient thought regarded peace as the most desirable thing and peace conditions as the ideal conditions of life. They praised peace in prose and poetry not less than we do, although they had, as we have, a full understanding of the greatness of war in itself, of its necessity and the enormous bene- 
fits for mankind which it sometimes brought with itself. "Polemos pater ton ergon," says one of the greatest Greek poets. I cannot trace in the whole ancient literature on this subject any difference in principle. Like other matters, we inherited our ideas on peace and war from the ancient Greeks and Romans.

An explanation of these different theoretical associations which have had and still have an enormous practical value must be sought in the domain of historical evolution. As a matter of fact, ancient society grew from conditions totally different from those influencing modern society. Civilized life formed for a long time small islands in the ocean of barbarism. Thus, for an ancient civilized state, neighbor was equivalent to foe. The ancient state evolved through the process of integration of petty political formations and this process assumed the form of ever-renewed wars. To this is due the constant state of war between the different civilized states, even of the same nationality. The general idea of war as the natural status influenced the forms of international relations and shifted from one focus of civilization to another. In this way the general principle took firm root, although the actual state of things was very often in contradiction to this main idea, as, I must add, our theory is so often in contradiction with the real state of things.

How different the history of international relations in the modern world! The family of European nations grew up not from conditions of war of all against all; modern European nations were children of the mighty and united Roman Empire, whose main foundation was general peace for the whole united civilized world. Orbis Romanus was for the Romans the Orbis Terrarum. Outside of it was barbarism,-no law, no right. The natural condition of this Roman world-state was peace-Pax Romana. It is symbolic that Augustus, the creator of the Roman world-empire, erected on the campus Martius, the field consecrated to Mars, the God of War, an altar to the deified peace, Ara Pacis. 
This fundamental idea never died out. It was inherited and proclaimed by the popes and the emperors of the middle ages, the exponents of the idea of the Holy Roman Empire, by the French monarchy, by the Signatories of the peace of Westphalia and down to our own times.

Although the points of departure of the ancient and the modern world in the domain of international relations were so utterly different, the forms in which these relations were expressed were almost the same, but of course they were used differently. The treaty as such was the main basis of these relations in the ancient world. Without treaty no established peace was possible and no regular and formal relations between the citizens of different states could exist. All was based on treaties; interstatal intercourse, intercourse between foreigners and the state, intercourse between foreigners and individual citizens, and the like. For this reason in the study of international relations of the ancient world a careful investigation of the different extant treaties must form the main foundation of our knowledge. It is a pity that we are still waiting for a continuation of the valuable and exhaustive collection of $\mathrm{R}$. Von Scala containing all extant ancient treaties. ${ }^{1}$ Nevertheless we must try to build up the general story of international relations on the ground-work of present available evidence.

\section{III}

MEANS OF. PRESERVING PEACE-THE BALANCE OF POWER

\section{IN ANTIQUITY}

The ancient world in its international relations aimed, like the modern, at building up, by all means, a general and lasting peace. But there are two different ways which lead to this goal. Both have been used by the ancient and the modern world, and neither was very successful. The first was to impose peace by force, a method used by im-

\footnotetext{
${ }^{1}$ Rudolf von Scala, Die Staatsverträge des Actertums, Leipzig, 1898 (Erstes Theil).
} 
perialistic powers, whose aim was the creation of a worldstate. All the existing states had to disappear in this mighty world-state and every attempt to recover liberty and independence was regarded as rebellion and suppressed by force of arms. The second way was that of inutual recognition and mutual concessions made by different states toward each other. This way led to the creation of a balance of power, a system of independent and free civilized states which were bound one to another by treaties and decided their controversies by means of peaceful understanding (international or rather interstatal arbitration) or by means of a regular war.

The history of international relations in the ancient world consists mainly in a record of the shifting of the balance sometimes towards the first solution, sometimes towards the second. Both systems failed in the final aim. As regards the world-state, Rome alone succeeded in creating for some centuries an almost general peace on this basis. But the price paid for this general peace was heavy enough. The results were, first, the stagnation of all creative efforts, and afterwards a bitter internal struggle which ended in a complete exhaustion and unheard of decadence of civilized life.

The attempts at building up a system of independent states, a family of states, were not crowned by lasting success in their main scope. Nor did they bring about general peace either. War after war interrupted the peaceful evolution of the ancient world during the periods of existence of the balance of power. But yet, whereas the epochs of the world-states were epochs of stagnation as regards new ideas and new forms of relations in the international life, the periods of the balance of power were great creative periods in all domains, including the domain of international relations and international law. Different forms of treaties and alliances, of federations, of arbitration, all the achievements in the domain of private international law were the results of these short periods when the systems of free and independent states, which 
mutually recognized each other's mutual rights, were prevailing.

Let me give you a short historical sketch account of this shifting of historical balance. This account will explain better than any theoretical considerations the reasons for the difference between the achievements of the ancient and the modern world in the realm of international relations.

We are hardly able, in the present condition of our knowledge, to decide the important question of the origin and first steps in the development of international relations in the ancient world. As far as we can judge, the most ancient legal expressions of international relations, besides war, were in the field of civil international law, - defining the relations of hospitality between members of different states and in the domain of public international law, comprising international or interstate treaties. What is the origin of those institutions? There are two attempts to solve this question. Some scholars affirm that these two institutions developed out of attempts to regulate international communications in conditions of peace, with the main aim of establishing commercial, social and economic relations. Others point out that the most ancient forms of treaties rather suggest their rise out of conditions of war, affecting, for example, a mitigation of the cruel right of the victor over the vanquished, or a. transformation of hostages into guests instead of slaves. or a change from unconditional surrender to a kind of treaty in the case of decisive victory, and from a truce to an equal treaty of peace in the case of an undecisive contest. I think that of the two factors each had its impertance, but that war and its regulation came first. chronologically. Considerations of peace relations came later on. They helped to mitigate the general state of war of all against all and to establish, on the basis of measures regulating war, a kind of legal procedure destined to create a peaceful intercourse.

In every case, as a matter of fact, the very first steps 
of mankind on the way to the development of a civilized life are marked by some forms which tried to regulate the interstatal relations. But from this starting point it is still a long way to generally accepted norms which were recognized as such by a common understanding of all the civilized nations and which were based on common religious sentiment and common moral feeling.

\section{IV}

\section{ANCIENT TREATIES}

The very first attempt to create civilized and organized political and social life in the ancient world, in the first states of Babylonia and Egypt, those petty tribal citystates built up by the Sumerians in Babylonia and by the native population of Egypt, brought about the first attempts to organize the interstatal relations between these different independent states. Already in the IV Millennium B. C., as we read, on a recently discovered cone of King Entemena of Lagash, a treaty of delimitation existed setting the boundaries between the two cities Lagash and Umma and it is noteworthy that the Kings of these cities chose as arbitrator of this contest Mesilim, the King of the neighbor city of Kish. ${ }^{1}$

This early period of a balance of power did not last long. Very soon the states of Babylonia and Egypt united into huge monarchical states whose main preoccupation was to defend themselves from the attack of wild tribes. But gradually along with the two states of Babylonia and Egypt another series of civilized and independent states arose and effected for the second time a kind of balance of power. Egypt, the state of the Hittites in Asia Minor, the Cretan maritime power in the Mediterranean, the powerful state of Mitanni on the upper course

${ }^{1}$ S. W. King and H. R. Hall, Egypt and Western Asia, 171; M. N. Tod, Journal of Transactions of the Victoria Idshitate, XLIV, 296; Tod, Arbitration, 171. 
of the Euphrates, Assyria, Babylonia, Elam, were the chief members of this system of states. And around them were many minor states-Palestine, the Phoenician towns on the Syrian coast, the Philistines, different Aramean states in Syria and such units. The big states were almost all equal in power; the small ones sometimes retained their independence by cleverly using the disputes of the big ones. Long and bitter wars did not end in a decisive victory for any one of the big powers. Each one of them was checked by various political combinations, by different defensive and offensive alliances, by treaties and by lively diplomatic activities of each of the above named states. Quite recently we became able to follow step by step the different phases in the history of this system of oriental states. The states-archives of the Egyptian capital, Tell-el-Amarna and later the archives of the Foreign Office of the Hittite Kings in Bogaz-Kevi offered an opportunity to read the various diplomatic letters written during many decades and to study the fundamental and quite elaborate treaty of alliance between King Rameses II of Egypt and Hattusili II of the Hittites. The treaty presents the most elaborate forms and contains even the clause of mutual extradition of political refugees. The treaty is dated of the year $1280 \mathrm{~B}$. C.

Let me cite some extracts from this venerable document to show you how elaborate it was and how nearly, mutatis mutandis, it resembles our own documents of the same type.

(1) Introductory Clause.

"The treaty which the great chief of the Hittites, Hattusili, the powerful, the son of Merasar, the great chief of the Hittites, the powerful, the grandson of Sapulul, the great chief of the Hittites, the powerful, made upon a silver tablet with Osymandyas (Rameses II), the great chief of Egypt, the powerful, the son of Men-mo-re (Seti I), the great chief of Egypt, the powerful, the grandson of Men-pelte-re (Rameses I), the great chief of Egypt. It is a good treaty of peace 
and alliance, setting peace (and alliance) between them forever."

(2) Historical sketch of former relations between the Hittites and Egypt. War and peace with the Hittite King Mutalla IV.

(3) Peace. "There shall be no hostilities between them forever. The great chief of the Hittites shall not pass over into the land of Egypt, forever, to take anything therefrom; Rameses, the great chief of Egypt, shall not pass over into the land of the Hittites to take anything therefrom forever."

(4) Defensive and offensive alliance. "If another people (or state) should come, as an enemy, against the lands of Rameses, the great chief of Egypt, and he shall send to the great chief of the Hittites, saying 'Come with me with your army against him,' the great chief of the Hittites shall come, and the great King of the Hittites shall slay his enemy. But if it shall not be the desire of the Great Chief of the Hittites to come, he shall send his infantry and his chariotry, and shall slay his enemy.

Or if Rameses, the great chief of Egypt, be provoked against delinquent subjects, when they have committed some other fault against him, and he come to slay them, then the great chief of the Hittites shall act with the lord of Egypt."

The same stipulation is repeated from the point of view of the Hittites.

(5) Extradition of Political Refugees.

"If any great men of the land of Egypt shall flee and shall come to the great chief of the Hittites, from either town, or . . . of the lands of Rameses, the great chief of Egypt, and they shall come to the great chief of the Hittites, then the great chief of the Hittites shall not receive them, but the great chief of the Hittites shall cause them to be brought to Rameses, the great chief of Egypt, their lord."

Similar clauses in the favor of the Hittites. 
(6) Religious sanction. Witnesses "of the thousand Gods, of the male Gods and female Gods."1

But once more this period of the balance of power was but of short duration. Invasions from outside weakened most of the states and this weakness was used first by the Assyrians and afterwards by the Persians to build up on the ruins of the system of states of the second part of the second millennium two subsequent enormous world-states, that of Assyria and that of Persia. Swords and arrows replaced treaties and international arbitration and diring the rule of the Persians, peace reigned over the oriental world interrupted only by some expeditions against barbarians (from the point of view of the Persians) and by some internal uprisings regarded by the Persians as civil wars. The Persian world-state seemed to have decided the future of the ancient civilized world.

Let me stop for a moment at this point in the evolution of the ancient world. We may see that already the first steps in the development of international relations produced the most conspicuous forms generally used even in the modern world for the purpose of regulating these relations: diplomatic intercourse, treaties, arbitration. But can we speak for this period of any international law? Hardly. Because, as I already pointed out, international law supposes a kind of general agreement on some principles, be they of legal or of moral and religious nature. This was not the case in the oriental world. The sole deciding force was might. Of course religious sanction of the treaties appears as a constant phenomenon of the oriental treaties. And I think this religious sanction was indeed an important factor.

The economic materialists will of course contest this statement and stubbornly affirm that the international re-

The document, engraved on stone, is preserved in Egypt. The Egyptian text, of which the above is a translation, is in turn, a translation from a Babylonian original, Babylonian being the diplomatic language of the II Millennium. Cf. Langdon and Gardiner in the Journal of Egyptian Archaeology, VI, 1920, pp. 179 and following. 
lations of bourgeois-states, i. e., of all the states known to history, except the most recent bolshevist Russia, were the exponents of constant economic struggle caused by "an insufficient development of productive forces, which strive to direct towards the external world the system of violent seizure."1 But the task of arguing with this sect is a hopeless one, and I think that in the domain of history they have lost their campaign entirely and finally. On the question of correlation between religion (and of course morals) and economics I may quote an incidental remark of Durkheim:2 "It is impossible to deny that the economic factor is very primitive at the dawn of history, whereas, religious life is luxuriant and all-penetrating. How therefore could the second proceed from the first?"

But we must take into consideration that religion shows different stages in its evolution. All the oriental religions remained purely national. The gods of the different oriental monarchies were friendly to their nation only and enemies of all other nations. As long, for instance, as the Assyrian chief god, similar in this respect to our old acquaintance, "the old German God", was a sworn foe of the Egyptian Ammon and the Persian Auramazda, religious sanction had but little binding force and the decisive word was spoken by force of arms. Periods of "balance of power" were under these conditions based on correlation of armed forces and military resources only. Morals and religion had no real importance.

The Persian Kingdom, as I have already pointed out, seemed to have created a lasting peace for the world in uniting all the oriental states under the rule of one King. But the plans of the Persian Kings met, as you know, with a stubborn resistance in a corner of the ancient world where they hardly expected it. From the ruins of the old Aegean civilization a system of petty and proud Greek city-states arose around the Aegean sea, on the

\footnotetext{
${ }^{1}$ Ciccotti, La Filosofia della guerra e la guerra alla filosofia, Milano, 1905.

${ }^{2}$ Rev. Philos, XLIV (1892), 650.
} 
Balkan peninsula, on the islands, and in Asia Minor. Each of these states created its own community, had its own gods, its own institutions, its own laws and magistrates. They all claimed full independence and were ready to die for it. Better to be exterminated and sold in slavery than to submit to the rule of a foreigner!

This land and this nation took up the inheritance of the oriental world, adopter its forms of international relations and diplomatic intercourse, but introduced in all these forms a new spirit, a new conception, which led to conditions, out of which arose not only international relations, but a real international law.

\section{V \\ RELIGION AS AN INFLUENCE IN INTERNATIONAL RELATIONS}

The new aspect of inter:ational relations in the Greek world was a result not only of another period of the balance of power in Greece, but also-and mainly-the result of great progress made in the domain of religion and morals. I have already pointed out that the Greek citystates zealously defended their political and economic independence. But this defense did not prevent them from a full recognition of their unity in respect of both nationality and civilization. The unity of the Greek world as it gradually developed, was based not on an exclusively racial, but mainly on a religious, moral and cultural foundation. The Greek world, even in its very beginnings, presented no national unity. From the Greek point of view, not every man of Greek extraction belonged to the Greek civilized world, as opposed to the barbarian; but every one was Greek who believed in the common Greek gods-the Olympians-for whom Zeus and Apollo were no mere sources of power, but creators of law and morals, for whom life outside the ordered conditions of a 
Greek "polis", that is, outside civilization and political freedom, could not be imagined; for whom Greek sanctuaries and games were real centers not only of national, but also of civilized life. We are too ready to forget that behind the curtain of Gieek national life lay the main force of Greek creative power-the force which had been able to build up a humanistic civilization, common to all civilized beings. Hence the cosmopolitan aspect of the ancient world and the. world-wide spread of Greek civilization.

The first step on this path was made when out of the ruin of petty tribal cults arose a pan-hellenic religion, the religion of the great Olympians, whose appearance both in abstract theory and as commonly portrayed was quite Greek and cosmopolitan. The statue of the Phidian Zeus and of his Athena are much more human than Egyptian and Assyrian gods, and at the same time they reflect in their superhuman, divine grandeur "the divine"-(To Theion) -in general much more than the poor symbol of the Persian Auramazda. It is no wonder that the classical images of the Olympians became so familiar to the whole civilized world and that we Christians naturally turned to the majestic model of the Phidian Zeus when we had occasion to seek an artistic symbol of the Deity. Hand in hand with this religious development went an enormous progress made by those deep thinkers, the Greek philosophers, in the domain of morals. One result of both these progresses was the recognition by all the Greeks of their religious and cultural as well as national unity. The manifestation of this recognition was the community of legal ideas in the domain of both civil and international law.

Never was the ancient world so near to surmounting the ancient belief in war as the natural condition of interstatal life as in the VI-IV century B. C. Never was it so ready to accept as normal the coindition of peace between the different Greek states, a theory altogether similar to our own modern concept. 
The main question in the domain of internaticanal law was: How to combine political independence and natinnal unity. The creative genius of the Greeks tried, beginning with the VI century, to achieve it by different means, partly borrowed from their oriental teachers in the domain of civilized life and civilized habits-treaties and arbitration, religious and political federations (amphictiones), -which prescribed to their members, in place of war, peaceful solutions of their quarrels by means of arbitration carried out by the council of the respective federation,-common sanctuaries of the great gods-the temple of Zeus at Olympia, that of Zeus at Dodona, those of Apollo at Delphi and Delos, whose oracles played an important part in regulating interstate relations-common games where all the cities came together to honor their common gods by different athletic contests and the like. The main attempts were made especially in the VI century. It seemed as if the time was at hand when Greece would succeed in creating a real league of Greek states and Greek tribes. The sixth century was a great creative epoch in the domain of international relations. War and force were still the decisive factors of political life, but along with them, we notice new ideas and new concepts, and, at the same time, new forms which converted these ideas into practice.

Let me deal with some of these forms more at length. They continued without change during the whole period from the VII to the III century B. C. The most important legal monuments of international relations were of course, the treaties. Greece recognized and used but one form of treaty, that of an equal treaty between two free and independent states. The Greek treaties are real Foedera aequa. Take any example you like in the book of Von Scala and you will find my statement fully confirmed. The sanction of all treaties was a religious one. The symbol of that sanction is the witness of the treaty, the supreme god, the incarnation of supreme justice-Zeus, the guardian of oaths and of good faith-(Zeus orkios kai pistios). 
Trexiles were used not only for the purpose of regulatitig post war conditions, but also as means of creating regular social and economic interstatal intercourse. Thus, commercial treaties were common and always assumed the same form. A treaty in Greece did not usually lead to relations of friendship or alliance, that is to say, to an assured federation of different states, but rather to a restoration of conditions of peace between two or more states. This shows how near the Greeks were to the concept of peace as a normal condition of interstatal life. This establishment of peace might have been agreed upon to last forever or for some years only. The most eloquent testimony for the common recognition of a national unity by all the Greeks is the regular clause in many treaties which usually appears at the beginning of the document, forming a kind of introduction. I mean the clause about the mutual guarding of common Greek sanctuaries. Even in the period when force began to dominate over right, on the eve of and during the Peloponnesian war, this idea found an adequate expression in many documents. The first point in the statutes of the projected league of Greek states proposed by Pericles in 447 dealt with this common guardianship and a common reconstruction of Greek sanctuaries destroyed by the Persians. Just at the beginning of the treaty between Athens and Sparta of April I2, 42I, which stipulated a peace for fifty years, we read: "Concerning the common sanctuaries: Anyone who wants may, without impediment, sacritice (in the sanctuaries) and consult the oracles and send sacred embassies according to ancestral custom, by land or sea. The sanctuary and the temple of Apollo in Delphi and the city of Delphi shall be autonomous, independent in matters of taxation and of jurisdiction, both as to the city itself and as to adjacent territory, according to ancestral custom."1

Only from this point of view are we able to explain the rather frequent cases of guarantee of inviolability giv-

\footnotetext{
${ }^{1}$ Scala, Staatsverträge, p. 67, n. 83).
} 
en to different Greek cities through different treaties concluded by them with other Greek cities. Such was, for example, the case of Teos in 193 B. C. I believe that inviolability was conceded to Teos because of its holy and famous temple.

\section{VI}

PEACE BY ARBITRATION IN THE ANCIENT WORLD

But the most interesting movement in Greece in the VIIV century was the movement towards settlement of interstatal disputes and misunderstandings not by war, but by international arbitration in a peaceful way. Arbitration was highly developed in Greece at this period. We find different types of the procedure. Some cases were settled by compromise, others as the result of a special treaty, one of the clauses of which asserted as obligatory the arbitration of all disputes arising out of the treaty itself. Some neutral states, appointed on a common understanding of the litigants, were to act as arbitrators. Let me introduce a brief sketch of the history of this institution taken from the book of one of the best specialists on the subject, Marcus Niebuhr Tod (Greek International Arbitration, Oxford, I9I 5, P. I74-I 78).

"That the Greeks were accustomed to arbitration from an early period in their history, is hardly open to doubt. Even if Pausanias' story that the Messenians offered to submit to arbitration their dispute with Sparta, which led to the outbreak of the first Messenian war, be rejected as the fabrication of a later age, reflecting back into the past the procedure familiar to itself, we can scarcely call in question the substantial truth of the traditions which tell of the arbitrations between Andros and Chalcis and between Athens and Mytilene, both of which episodes belong to the VII Century, while the arbitral settlement, early in the VII Century, of the struggle waged between Athens and Megara for the possession of Salamis is assuredly historical, however much later imagination may have busied itself with embellishing the tale of Solon's ad- 
vocacy of the Athenian course. Of any essential modification in the methods of arbitration between the earliest times to which our records refer and the close of Hellenic independence we can discover no traces. Nor should we be justified in looking for such, since arbitral awards, though dealing normally with questions which are legal in their nature, are based not upon law, at least in the Greek World, which knew no codified international law, but upon equity, and equity is far more stable than law.

"By the middle of the fifth century-how much earlier than that we have no means of determiningthe Greeks had taken a decided step in advance. Instead of awaiting a deadlock and then consenting to refer it to arbitration, they bound themselves on some occasions by treaty to deal in this way with any dispute which should arise out of the failure, alleged or real, of either of the contracting parties to observe the terms of the treaty, or indeed with any difference which might threaten to disturb the peaceful relations between the states.

"For awhile the sanguine hopes of those who looked for great results from this stipulation seemed doomed to disappointment. Time after time during the troubles which thickened on the eve of the Peloponnesian War, the Athenians appealed to the compromise clause inserted in the Thirty Years' Peace, but in vain, and before that peace had lasted half its span of years, Athens and Sparta were again at war. . . . Yet this failure of arbitration to avert a disastrous war did not, as some observers may have feared at the time, sound the death-knell of the institution. It emphasized the truth that arbitration does not act automatically, that it is an instrument the efficiency of which lies in its use. Even in Sparta there were doubtless many who echoed the words of Archidamus that, since the Athenians offered arbitration in accordance with the terms of the Peace, it was contrary to the law to attack them, words which were probably recalled time and again during the long years of futile war and harassing anxiety which followed. Even those who had voted for war felt, in 
their calmer moments, that they had put themselves in the wrong by refusing the Athenian invitation to settle the dispute by arbitration, and attributed to this cause in great part the disasters which overtook them at Sphacteria and elsewhere. And so we find that arbitration clauses are inserted in the Year's Truce of 423, in the Peace of Nicias (421) and in the Alliance of 418 between Sparta and Argos."

In the fourth century our evidence is more scanty, yet we have some six or seven examples for the time before Alexander and the scarcity might be explained by the character of our sources. There is no Thucydides to give us the text of the more important treaties. Thus, I entirely agree with Tod that "this period was one in which the employment of arbitration was gradually spreading over the entire Greek World, and even the smaller states were becoming more familiurized with this mode of putting an end to disputes with their neighbors." From the Greek states, the habit extended even to their so-called barbarian neighbors. The most interesting case is that of the Romans and the Tarentines. "The Tarentines demanded that the Romans and Samnites should desist from their war-like preparations and submit to them the settlement of their differences." The answer of the Romans to this proposal is characteristic enough. They paid no attention to those whom they scorned as a "Vanissima gens,"- the most frivolous of peoples which, although unable to settle its own domestic revolutions and discords, thinks itself competent to dictate to others conditions of war and peace.

\section{VII}

\section{DIPLOMATIC AGENTS IN ANTIQUITY}

It was in the Greek World also that diplomatic relations not only became constant, but that these relations assumed regular and generally recognized forms. All interstatal business was transacted through embassies and Ambassadors. To be sure no permanent embassies were maintained 
by the Greek states in other states; but such permanent embassies were, in the conditions of Greek life, both useless and almost impossible. How many embassies was a small Greek state to maintain, when there were some hundreds of independent states in Greece alone? Nevertheless, the part played by diplomatic representatives in the ancient world was important enough. It is true, there existed no professional diplomats in the Greek cities just as there existed no professional politicians. Every citizen was perfectly acquainted with the political situation and was able to carry out successfully important diplomatic missions. As a matter of fact, the popular assemblies were very careful in electing for these missions their most experienced citizens, men who possessed a good knowledge of both the actual political situation and the peculiar conditions of the state to which they were to be sent.

One of the most common tasks of the popular assembly was to send and to receive embassies, to hear and to criticize the reports of embassies who came home and to give instructions to embassies going abroad as well as to discuss the proposals made by foreign ambassadors. I suggest that you read the vivid and amusing picture of such an assembly in Athens, drawn by Aristophanes in his famous play the "Acharnians," where the people are shown receiving reports from their embassies which have returned from Persia and Thrace, and questioning the Persian ambassador, Shamatarbas, the "King's Eye," in a most searching manner. ${ }^{1}$

The only difference between the diplomacy of antiquity (Greek and Roman antiquity, not that of the Orient) and modern diplomacy consisted in the fact that ancient diplomacy very seldom had recourse to secret proceedings and treaties; almost all the work was done in co-operation with the upper house and the popular assembly. It is almost needless to add that the ambassadors were inviolable and exterritorial, that is, exempt from the civil jurisdic-

${ }^{1}$ Botsford, A Source-Book of Ancient History, p. 196 fol. 
tion of the place where they were temporarily residing. Cicero, using of course Greek ideas, well expresses the principle of the inviolability of ambassadors, as follows: "The inviolability of ambassadors is protected both by divine and human lave; they are sacred and respected so as to be inviolable not only when in an allied country, but also whenever they happen to be in the midst of the forces of enemies." (Cicero-in Verr III.)

Of the greatest interest are the measures taken by the Greek cities to protect the material interest of aliens who resided in their cities. We may notice even a kind of attempt to create some permanent representatives in foreign cities whose duties were to watch over the interests of both the city which they represented and its individual citizens. I refer to the well known institution of the proxenoi which developed out of the already mentioned relations of hospitality between individual citizens of different cities. From the $\mathrm{V}$ century on, the proxenoi often became official representatives of the city which gave them the rights of honorary citizenship. They were appointed for the special purpose of acting as permanent consular agents. Sometimes they assumed diplomatic duties. One of their chief functions was to guide the assemblies and to present them to the magistrates, the council and the popular assembly of their city. We must not forget, however, that the proxenoi were always citizens of the city in which they represented the interests of another city.

Still more significant is the rich development of international jurisdiction. I cannot deal with this point at length. You may find a good survey of the different kinds of this jurisdiction in Philippson. Let me cite a short quotation from his valuable book. (v. I, p. 208.) ${ }^{1}$

"Generally speaking, in time of peace, freedom of intercourse, and especially of engaging in mercantile transactions (epimixia corresponding approximately

'Philippson, International Law and Custom of Ancient Greece and Rome, Vol. I., p. 208. 
to the Roman ius commercii) was permitted between the citizens of different states, subject to the payment of customs duties, port-dues, etc., and in some cases, to restrictions respecting the exportation and importation of certain commodities, such as oil, grain, etc. In most towns, there was a permanent court exercising jurisdiction over causes to which aliens were parties; and this judicial organization, as well as the presiding judges, were variously designated, so that we hear of the "Xenicon dicasterion" (a general name for the foreign court) the "Xonodikoi" (a general name for the presiding judges), the Polemarchos (the Athenian Archon, who took special cognizance of the affairs of aliens), the "cosmos xenios" (of Cretan towns), and the like. These institutions and magistracies usually existed apart from express provisions in international conventions, but treaties were very frequently concluded either to insure the due and impartial operation of these tribunals, or to establish a new mixed court of judges, the coinon dicasterion, and, at the same time, nominate a third city, as a "court of appeal," in the sense of a tribunal to which the issues were submitted for final decision after a preliminary examination by the court of first instance. As to the law that was applied in the settlement of conflicting claims, sometimes the lex loci contractus (the prevailing law of the place where the engagement in question was entered into) operated, at other times the lexdomicilii of the defendant; sometimes, again, broad and equitable principles were invoked in order to effect a fair reconciliation between the contending legislations of the States concerned, and, finally, an express judicial dispensation might be resorted to in virtue of an ad hoc agreement. At first the alien suitor was obliged to plead through the agency of the proxenus or his patron, as the case may be, but with the expansion of commerce and general intercourse, the increase of litigation and the more generous attitude that came to be manifested towards non-citizens, the foreigner was, in actual practice, and despite strict theory, commonly allowed to appear in person and address the court, and to install 
advocates to plead for him. Finally provision was usually made for the hearing of suits within a certain fixed period, so as to prevent an undue delay of justice."

Space does not allow me to deal with the new ideas and institutions given form and effect by the Greeks of this epoch, in order to mitigate the cruel customs of warfare. I refer to the different guarantees of neutrality, the regulations of the fate of the prisoners, the treatment of the hostages, and so on. I hope to be able to devote a special study to this question.

Such were the achievements of the Greek World in the domain of international relations. Their main aim was gradually to transform Greece into a family of states where right worked beside force, and we must say that right did not always yield to force. Can we honestly claim more than that for our own modern conditions?

\section{VIII}

\section{CONFLICT BETWEEN RIGHT AND FORCE}

I have already pointed out that the Peloponnesian war interrupted the quiet development of international relations based on religion, morals, equity and law. This war undermined the foundations of international law and led the world back to the crucial dilemma; - has force to yield to right, or right to fcrce? We cannot deny that the triumph of force over right was a result not only of the political development of the Greek World, but also of a strong intellectual current headed by the so-called sophists who sought and found theoretical proof for their thesis as to the dominating part played by force in human life. In international relations the principle was worked out as the predominance of the interests of the state over the interests of law and justice.

Let me bring forward some quotations from different political speeches of this epoch transmitted to us by Thu- 
cydides. They will show how great was the difference between the two points of view. The Corinthians, for example, had occasion to formulate the old principle of Greek morals. It was on the eve of the great war, in 433. "Do not say to yourselves that one thing is just, but that in the event of war another thing is expedient; for the true path of expediency is the path of right. . . . To do no wrong to a neighbor is a more certain source of power than to gain a perilous advantage under the influence of a momentary illusion." (Thucydides I, 42.) The new sophistical point of view is fully expressed in an answer given in 432 by the Athenian ambassador in reply to arguments of the Spartan magistrates similar to those of the Corinthians quoted above. It reminds us on one hand of the discussion of the same problem by the sophist Thrasymachus and Socrates in one of the dialogues of Plato (The Republic I), and on the other hand of so many proclamations and pamphlets published during the great war by the Germans.

"An empire was offered to us," said the Atheniar: ambassador. "Can you wonder that, acting as human nature always will, we accepted it and refused to give it up again, constrained by three all-powerful motives -ambition, fear, interest? We are not the first who have aspired to rule; the world has ever held that the weaker must be kept down by the stronger. And we think that we are worthy of power, and there was a time when you thought so too; but now, when you mean expediency, you talk about justice. Did justice ever deter anyone from taking by force whatever he could?" (Thuc. I, 76.)

The prevailing of these ideas brought with it very important results. First Athens and then Sparta dominated the Greek world. The balance of power seemed to be gone forever and force appeared to have triumphed over right. And yet it was not so. Although might was the deciding factor it was never supported by public opinion. The oppressor was always recognized as such and this moral censorship made certain the weakness of all im- 
perialist attempts based on force alone. We have already seen that treaty-making and arbitration were being developed in spite of frequent wars and we are not surprised therefore that Sparta's victory over Athens did not create a lasting hegemony for her. A kind of balance of power was soon re-established. But the balance of power of the IV century B. C. was more like a state of political anarchy than an order by system of independent states-an anarchy which considerably weakened Greece as a whole and enabled first the Persian King, and later the Kings of Macedonia, to dictate their will to the different political combinations which appeared and disappeared in Greece like mushrooms. This process of complete disintegration was ended first by the so-called peace of Antalkides ( 386 B. C.), which made Greece subject to the Persian King, and later by the battle of Chaeronaea which established Macedonian domination in Greece. And yet this troubled period in the history of Greece, full of wars, social unrest and revolutions, was an epoch of important progress in the domain of international relations. Hand in hand with the growing process of disintegration went the process of varied attempts to settle interstate conflicts in a peaceful way. I have already spoken of arbitration. We may notice the same evolution in other domains. Diplomatic intercourse was never before so lively or so elaborate. Warfare was better regulated by international understandings and by the force of public opinion than in the VI and V Century. New and progressive forms of relations between governments were created, such as the different federations of Greek cities (the Achaean and Aetolian federations).

\section{IX}

\section{PERIOD OF CONSTANT FLUX}

The next stage in the political evolution of the ancient world was the reestablishment of the world-state by Alexander the Great. This was the substitution for the Per- 
sian domination of a world-domination of Greek elements united around the Macedonian state. The world-monarchy of Alexander was in no respect a new political form. Alexander preserved all the peculiarities of the Persian empire. The only change brought in by him was the substitution of a new dominating class for the old one. The Greeks and Macedonians replaced the Iranians as the ruling element. Greece remained legally free, but in fact it was simply a portion of the new world-state. Indeed, the "freedom" of Greece was strongly emphasized by the new ruler, but this freedom meant of course protection, like the freedom of the peace of Antalkides and subsequently the freedom of the peace of Flamininus. Alexander's world-empire did not last long. The disintegrating forces within the empire were too strong to maintain the artificial unity of the Greek Occident and the multi-national Orient. Alexander's empire soon fell to pieces and out of its ruin arose many powerful GraecoOriental states. The leading powers were-Syria, Egypt, Macedonia.

Two processes might be noticed during the so-called Hellenistic period. One led towards the reintegration of the Persian and Macedonian World-empire, while the other opposed this movement towards centralization by all means and resulted in separating from the big states new political formations, both kingdoms and city-states: Pergamon, Bithynia, Galatia, Pontus, Cappadocia, Commagene, Armenia, Parthia, on one side and Rhodes, Sparta, Athens, and the Achean, Aetolian and Lycian federations on the other. Thus there once more reappeared the balance of power which lasted this time about two centuries and which was as creative in the field of international relations as had been the earlier balances of power,that of the second millennium B. C. and that of the Greek city-states of the VI-IV century B. C. Diplomatic relations were lively and constant. Never before was exchange of embassies and special envoys so regular and the matters discussed by them so complicated. Never before 
were concluded so many treaties, which of course were broken sometimes within a few months of the dates of signature. Never before and never after was international arbitration in such constant use, to be sure, principally between the legally "free" but practically "protected" petty Greek states. Those who acted as arbitrators were generally the mighty protectors, the kings of the great Monarchies. Wars were conducted in the most chivalrous manner, were of short duration, and led generally to new political combinations defined by elaborate treaties.

The most important process during this period was that of a gradual formation of a world civil law, of a Reichsrecht or Jus Gentium. The extreme mixture of races in all the new states, the constant emigration from one centre to another, the numerous colonies of "foreigners" in all the Hellenistic states like the Jewish colonies in Egypt, Asia Minor and Greece, called imperatively for the creation of a system of law equally intelligible to all the constituent parts of the cosmopolitan states of this epoch. An intensive world-commerce everywhere required standards calculated to facilitate commercial relations and based on generally accepted principles.

The main outline of this new international law was taken from Athens, whose world-commerce preceded that of the Hellenistic epoch. The different codes of laws published in different countries were practically all based on the Athenian laws. Just as in matters of language, a kind of juridical common agreement (Koiné) guided the decisions of the different courts which acted in different countries. This enormous work was not carried out to the extent of formulating an international civil law, but it went far enough to enable Rome during the period of her world-domination to build up her system of worldcivil law on a basis of equal application throughout the constituent parts of the Roman Empire.

In one branch, however, we may notice quite positive and practically definite results. I mean the general maritime law, elaborated and put into general circulation by 
Rhodes, which acted in this respect as a kind of mandatory of all the Hellenistic powers interested in the safety of the seas and in an undisturbed maritime commerce. ${ }^{1}$

Nevertheless, we must confess that the Hellenistic epoch was by no means a triumph of right over might. Force and fortune were the watchwords of this epoch. But the period in itself had its great importance. Besides the development of civil international law which gradually assimilated with the civil law in general, we witness during this period a spread of Greek ideas over all the world. What had been an interstate law of Greek citystates then became the unwritten code of rules and custom, forming a kind of foundation for the international relations of the whole civilized world both in the Orient and in the Occident, in Syria and Egypt as well as in Carthage and in Italy. Force and the interests of the States played, of course, the predominant part in the complicated life of this period. But the standard-bearers of this force were Greeks. They belonged to the Greek World and were brought up in the principles of Greek civilization. Their mentality and their education were Greek and their ideals as well. We can readily understand why Greek ideas on international relations formed a kind of subconscious stratum in the acts of the political rulers of the Hellenistic world. It must be borne in mind, however, that the most important feature of the Hellenistic age was not any new achievements in the field of international law, but the gradual transformation of its principles into institutions which helped to organize the internal life of the vast and complex states of this epoch. I need only mention again, in this connection, the use of international arbitration and civil international law.

\footnotetext{
${ }^{1} \mathrm{~S} . \mathrm{W}$. Ashburner, The Rhodian Sea Law, Oxford, 1909, treats not the Hellenistic Law of Rhodes but a Byzantine derivation, as I incline to think, of the Hellenistic original. On the Hellenistic law, see Van Gelder, Geschichte der Alten Rhodier.
} 


\section{$\mathrm{X}$}

\section{THE ROMAN THEORY OF INTERNATIONAL RELATIONS}

This process was further developed by Rome, who inherited from the Hellenistic world not only the main ideas of world-power, but also the various legal forms used by the Greeks. But the whole system of Rome's international relations, although influenced by Greek achievements, was peculiar and independent. Greek influence did not change its main character. Generally speaking the Roman system, though quite elaborate, was based on more primitive and more elementary conceptions than those elaborated by the Greeks. The main Roman idea was the ancient one of war as the natural status of international intercourse.

The difference between Greece and Rome as regards international relations found an adequate expression in the utterly different treatment by Greece and Rome of international treaties which formed the basis of international relations in both countries. The Roman treaty was never a treaty which contented itself with restoring peace between herself and another state, that is, their previous normal relations. Rome's treaties always created one or another kind of perpetual relation between the two parties, either of friendship or of alliance. Both of these relations were certain to give rise to a definite legal status between the two states. Of course, originally these legal relations were elaborated on a basis of equality, and the form of the Roman treaty is that of an equal treaty (foedus aequum) between independent states. But gradually, by means of clauses added to the body of the treaty, the treaty of friendship became transformed into a treaty which effected vassalage, the treaty of alliance into a treaty of dependence. Both forms of treaties were, of course, intended to last an indefinite time. Thus it came about that Rome did not know treaties limited in time, but only treaties of supposedly unlimited duration. 
Another fundamental point in Roman international practice and theory was that Rome, in her estimate of justice or injustice, of legality or illegality, of all acts of an international character, took not an international but exclusively the Roman point of view. The sole question for Rome is always: Does one or another act correspond to the political and juridical standards prevailing in Rome? Does it or does it not fulfill the requirements of Roman morals and religion? For Rome justum bellum "the righteous war" was a war declared by Rome with due regard for the usual religious and legal forms and with all the formalities prescribed by the body of international and religious customary principles elaborated and interpreted by the College of Fetiales. Every war must have had some legal cause, but legal from the point of view of existing Roman law. Therefore, the Romans were right in declaring that they never conducted any but legal wars (iusta bella). "Legal" meant in their mind both legal from the juridical point of view and "just" from the moral point of view. The treaties concluded by the Romans were always formulated according to a certain type elaborated once for all by themselves. This type was regarded as, and intended to be, a foedus aequuman "equal treaty". But it also would frequently comprise supplementary clauses, which might change the whole character of the treaty. Nevertheless, from the legal point of view the treaty was always to be regarded as one concluded with due regard for all the forms of the law of Rome.

From the same point of view, Rome guided the civil intercourse between herself and other cities. The socalled jus gentium of the Romans was nothing but Roman civil law adapted to the regulation of the relations of Roman citizens and citizens of other cities which were friends and allies of the Roman people. With men who did not belong to these two categories, Rome was supposed not to have any legal relations whatever. We read, for example, in the Digest 49, I5: "If with certain na- 
tions we have no connection of friendship or hospitality and no treaty concluded in order to establish friendship, the men of these nations are not our enemies (hostes) (a concession to Greek ideas) but if anything belonging to us happens to come into their possession, it becomes their own and a free man of ours taken captive becomes their slave; the same in the case of anything belonging to them if it comes into our hands."

When Rome came in close contact with the Greek world she adopted many details of the Greek international usage. Rome made her own the Greek system of diplomatic relations; she modified many expressions in her treaties, she used the procedure of international arbitration, as Persia and the Hellenistic monarchies had used it before her, exclusively regulating relations between her Greek allies. But Rome never modified the essence of her international principles and never adopted the fundamental ideas of Greek international law.

By force of arms, Rome secured for herself a unique position in the family of civilized nations. As the Roman forms of international law were well adapted to this paramount position, Rome never seriously contemplated changing them, but retained them throughout her history. She ordered and expected to be obeyed. Even when she acted as arbitrator, she expected to be obeyed. Let me cite but one example. Antiochus IV, King of Syria, attempted to conquer Egypt. He was with his army in Egypt and was moving towards Alexandria. Suddenly his way was barred by the Roman praetor, Popillius, with his staff, but without an army.

"Popillius, the Roman praetor," says Polybius (XXIX, II) $(2,27)$, "was greeted at a great distance by the king; he did not accept the hand which was stretched towards him, but gave the king tablets, on which was written the Senatus-consultum; he demanded that the king should first read the Senate's decision. . . . After having read this senatus-consultum 
the king answered that he must confer with his friends, as to how to act. But Popillius . . . who happened to have in his hand a vine-stick traced a circle in the ground around Antiochus and required the king to give an immediate answer. The king, struck by this haughty behavior, after a brief period of hesitation, declared that he would do all that was ordered by the Roman people. . . . It was set forth in the senatusconsultum that the king was immediately to end the war against Ptolemy."

It was thus that Rome created her world-state. But we must not forget that this state was built up by incorporating in it all the Hellenized parts of the ancient world and that the western parts of it were shaped according to Greek models. In the internal structure of her worldstate Rome introduced many principles which had been evoked in the international law of the Greeks, for the Roman world-state was an international state. Moreover, Rome brought to a point of realization many Greek aspirations which could never have been accomplished by the Greek World. Common peace became a reality, likewise a world system of civil law.

It is evident that even after having established her world empire Rome had to deal with neighbors, both in time of war and in time of peace. Therefore diplomatic relations with them never ceased to exist. ${ }^{1}$ But from the point of view of international law, Rome never recognized the legal existence of the German or Iranian states. She never treated them as her equals.

Let me conclude this paper on the international law of the Ancient world by quoting the words of Augustus, the founder of the Roman Empire, as to his international achievements. In his statement to the Roman people, which he himself carefully composed and ordered to be

${ }^{1}$ One of the most interesting institutions of this epoch is the corps of diplomatic interpreters, the forerunners of our "dragomans" in Oriental countries. Cf. J. Snellmann, De Interpretitus Romanorum, Leipzig, 1920. 
engraved, after his death, on bronze pillars posted before his mausoleum, he said:

"I extended the frontiers of all the Roman provinces which are bordered by peoples not subject to our dominion." After having enumerated these conquests of his, he proceeds: "To me there were often sent embassies from India, such as had never been seen by any one of the Roman commanders. Our friendship was besought by embassies of the Bastarmians and Scythians, of the kings of the Sarmatians, who dwell beyond the Tanais and further to the east, of the king of the Albanians, as well as by emissaries of the kings of the Iberians and the Medes." . . . "To me, Phraates, the son of Orodes, sent all his sons and grandsons, although not vanquished in war, but in order to ask our friendship by giving us his sons as hostages. During the time I held the office of princeps, peoples that had never before had any exchange of embassies and friendship with us were acquainted with the good faith (fides) of the Roman people."

The words of Augustus in which the Roman conception of her supremacy over the world were so proudly expressed became a kind of gospel for his successors. The Roman theory which did not recognize any equals to the Empire,- the only "legal" world-state,-remained unchanged as long as that empire endured.

Such are the essential features of the development of international relations in the ancient world. Like our own, they very often change their aspect. Antiquity had its epochs of creative work and its periods of stagnation and decay. But some fundamental concepts and some general ideas, once accepted, were never forgotten. Although apparently the modern world began its evolution in somewhat primitive conditions, we must not forget that these conditions had as their foundation all the most important ideas of the ancient world, and, first of all, the Pax Romana and the common Christian faith.

\section{MICHAEL ROSTOVTSEFF.}




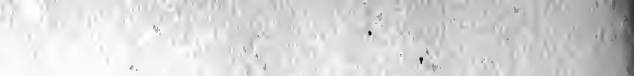


Medieval Diplomacy 



\section{MEDIEVAL DIPLOMACY}

\section{I}

THE MEDIEVAL HERITAGE

In spite of calumny against the Middle Ages on the part of a past generation of modern historians and in the teeth of the resultant popular prejudice nowadays against the very word "medieval," there has been in the last century an ever-growing appreciation among scholars of the vast debt which we moderns owe to the Middle Age. The Middle Age is the bridge between the Roman Empire of antiquity and the national states of modern times. It is the medium through which antique culture has been transmitted to our contemporary world. Nay, more; it is the living organism in which have germinated and developed the cardinal institutions and customs of the present day. In a real sense the Middle Age is the mother of modernity.

We moderns usually admit, since the time of Chateaubriand and Schlegel and Ozanam, that the artistic and romantic heritage of the Middle Age has been considerable - Gothic architecture, illuminated manuscripts, tapestries and embroideries, the songs of the troubadours, the paintings of a Giotto, the poems of a Dante. But this is only one aspect of what present-day scholars recognize as our debt to the Middle Age. Mr. Rashdall has attributed to it the genesis of our ideas of university-organization and university-education. Dr. James J. Walsh has ascribed to it the patronage of experimental science and remarkable progress in astronomy, engineering, and medicine. The late Professor Maitland emphasized the medieval character of the English common law and administrative pro- 
cedure as well as the essential medievalism of our institutions of representative government and trial by jury. Moreover, contemporary political scientists are making the Middle Age the field of their researches into the nature of sovereignty and functional representation; and leaders of the present gild socialist movement in England are seeking to solve social and economic problems by recourse to medieval ideas and medieval practices. And no sooner is a League of Nations projected than students of international relations and diplomacy turn back to the times which witnessed the most fruitful growth of these things-the Middle Ages.

Before undertaking to appraise the influence of the Middle Age upon the evolution of diplomacy and international relations, it is important that, we recognize certain outstanding characteristics of the period itself. One of these characteristics is the absence of any political institution uniting all civilized peoples in a common secular bond, such as the Roman Empire had been in ancient times, and the substitution of a most bewildering provincialism and localism. In the fifth and sixth centuries of the Christian era the Roman Empire finally fell a prey, so far as central and western Europe was concerned, to the spasmodic incursions and constant immigration of semi-barbarous Teutons from the forest and swamps to the north. These Teutons, like all primitive peoples, were clannish and quarrelsome; devoted to their own folktraditions, they cared little for the traditions of cultured Greeks or cultivated Latins; they had neither the natural bent nor the intellectual equipment to enable them to maintain intact the might and majesty of the universal Roman Empire. As the Teutons settled down within the confines of the Empire-Angles and Saxons in Britain, Franks and Burgundians in Gaul, Visigoths in Spain, and Lombards in northern Italy - they acknowledged no political obedience save to their tribal kings and to their military chieftains. At the same time they modified the landowning and agricultural system of the Roman provincials in 
accordance with their own customs and adapted it to their own uses. And gradually, from this juncture of circumstances, there evolved the distinctively medieval institutions of the manor and of feudalism, and the almost equally distinctive practice of private warfare. There is a basic truth, as well as a pun, in the statement that the feud was a natural accompaniment of feudalism.

In other words, local dominion supplanted world dominion in the Middle Age. The principle of universal law was pushed into the background. And instead of recruiting and utilizing legionary soldiers for the preservation of a Pax Romana, the kings and dukes and counts of innumerable medieval principalities armed their respective retainers and waged war freely with one another.

As the Middle Age progressed the worst of these features of localism tended to disappear. The Teutons were gradually civilized; feudalism was slowly subjected to a central political authority; and private warfare was curbed. Yet so ingrained was the spirit of provincialism in the hearts and minds of medieval men generally from the fifth to the fifteenth centuries that these later achievements paved the way not for the restoration of universal empire and universal peace, but for the establishment of sovereign national states on the basis of the tribal kingdoms and for the development of a regular system of international relationships, not least notable among which was the relationship of war.

One of the major characteristics of the Middle Age, then, is localism. But it is localism in fact rather than in theory. For such medieval persons as cared for theories -and there were very many such persons-world dominion still appealed with irresistible force and logic as an ideal. Paradoxical as it may seem, the ancient idea of universal empire dominated the Middle Age side-by-side with actual feudalism and tribal monarchy. The theory was far more conservative than the fact, and both were equally characteristic of medieval Europe. 
Long after the disruption and deliquescence of the Empire of the Caesars, the Roman imperial concept survived. Greek rulers at Constantinople called themselves Roman emperors and laid claim to secular supremacy until the final extinction of their little state by the Ottoman Turks in 1453. The stalwart Frankish Chieftain Charlemagne temporarily federated divers Teutonic tribes and had himself crowned as Roman Emporer in 800. And in 962 the German prince, Otto the Great, was so impressed with the imperial concept that he, too, appropriated the imperial title and, in effect, created that Holy Roman Empire of the Germans which endured throughout the whole Middle Age and as a fiction, down to the time of Napoleon Bonaparte in 1806 . The pretensions of this medieval Holy Roman Empire to secular supremacy and worlddominion were as pompous and embracing as its actual position was preposterous. Neither the Holy Roman Emperor in Germany nor the Graeco-Byzantine Emperor at Constantinople would recognize as equals the sovereigns of the kingdoms that were growing up about them; and without at least a theoretical equality of independent sovereign states international relations in the modern sense were impossible. Localism, one characteristic of the Middle Age, tended to prepare the way for internationalism; the survival of the imperial concept, a second characteristic of the Middle Age, tended to block or impede that way.

The third and last of these medieval characteristics to which I would especially invite your attention is the ecclesiastical. Throughout the entire period from the fifth to the fifteenth centuries the great bulk of Europeans with whom we have to deal were members of the Catholic Church, inheriting the religious truths and moral precepts of Jesus of Nazareth, that Divine Revolutionist in the midst of the ancient Roman Empire, and living in their own day under their priests and bishops graded in a vast hierarchy up to the bishop of Rome, the Pope, Christ's vicar on Earth. Amid all the changes which at- 
tended Teutonic immigration and incursion, there was one form of authority which did not change, except to increase its importance. Not only did the Church preserve ancient culture and convert and civilize the barbarians but it was the only bond of union which still held together the fragments of the old Roman world. The Teutonic kingdoms tended toward local isolation, but the Church supplied a medium of general intercourse. Everywhere in the West its traditions and interests were identical, and the turmoil and upheaval of the time only strengthened its sense of solidarity.

This point cannot be stressed too emphatically. Just when the Roman Empire was disintegrating and when feudalism was developing with its localism and private warfare, the persistent longing for universality found fruitful expression not so much in a Byzantine Empire or in a Holy Roman Empire of the German Nation as in the concept of Christendom. And Christendom was a fact, not a theory. For the Catholic Church of the Middle Age, especially its central agency, the Papacy, directed the conscience of Europe, legislated for the newlyconverted peoples, and drew to itself the representatives of every civilized tribe, and in doing all these things the Papacy could not fail to impress on Christian peoples, whether of Scotland or Italy, whether of Spain or Hungary, a sense of their common faith. It was the Papacy which, therefore, at one and the same time, by treating each nation as a separate unit, expressed in a primate with his suffragan bishops, and yet by legislating identically in matters of faith and morals for all the nations, expounded a two-fold thesis of nationalism and internationalism. The Catholic Church was by all odds the most important distinctive institution of the Middle Age, and the Catholic Church never ceased to insist that the nations were separate individuals, yet members of a Christian brotherhood, that they were moral persons yet subject to the common law of Christendom. 


\section{MEDIEVAL CHURCHMEN AND INTERNATIONAL LAW}

Politically Europe was divided during the greater part of the Middle Age into two Empires-the Byzantine and the Holy Roman-and a large number of tribal kingdoms. Socially during the same period Europe was subdivided into principalities and baronies-the estates of feudal nobles. If these divisions and subdivisions are viewed as centrifugal forces in Christendom, the Papacy and the Catholic Christian Church which it represented and for which it authoritatively spoke, must be considered as a counterbalancing centripetal force. All Christendom continued to look to Rome as the centre of world unity, albeit now it was the Rome of the popes rather than the Rome of the emperors.

The words of Christ to Saint Peter and the tradition of the popes as bishops of Rome and successors to the Prince of the Apostles would suffice to explain why the papacy was generally recognized and honored as the religious and moral head of Christendom. But apart from strictly religious and theological considerations, the influence of the papacy was undoubtedly strengthened by a curious political and territorial situation. It so happened that the only state in the Middle Age which had direct continuity with the ancient Roman Empire was that commonly known as the Byzantine Empire, with its capital at Constantinople; and Rome was so far away from Constantinople and so separated from it by restless Teutonic tribes that the Byzantine emperors were never able to subject the popes to their political sway. The result was that fairly early the bishops of Rome came to exercise political, as well as strictly ecclesiastical, power in central Italy. Moreover, the reestablishment of an empire in the West, whether of Charlemagne or of Otto the Great, was effected by papal action. And when it is borne in mind that most of the Teutonic tribesmen were converted to Christianity by missionaries despatched from Rome, and 
that practically all medieval kings were crowned by bishops of the Catholic Church, it is easy to understand how and why the Catholic Church and the Papacy, instead of becoming mere adjuncts to secular governments, rose superior to them and served not only as spiritual cement but also as political mortar.

Christendom of the Middle Age, like the Roman Empire of ancient times, was, in a sense, a federation of many nations for the purpose of preserving peace both within the federation and against barbarians outside. But while the ancient emperors were primarily political and military autocrats who incidentally utilized religion to serve their ends, the medieval popes were first and foremost religious and moral leaders, who from the exigencies of the times exercised political and even military power.

There was another contrast between the ancient Roman Empire and the Medieval Church of special significance to us. The Roman Emperors exercised direct political sway over so many nations that they could recognize no international law in its modern meaning. In their time there was hardly an international society; the Roman and Parthian Empires between them divided the civilized world in which international relations on anything like an equal footing were possible. And the justly celebrated Roman jurists, who conferred upon posterity the heritage of the Roman civil law, never worked out a system of international law. To be sure, the jurists expounded the ius gentium (the "law of nations"), but it was common law based on the ius naturale (the "law of nature"), for the benefit of foreigners living within the Empire, rather than international law in its modern significance. On the other hand, the Catholic Church of the Middle Age exercised universal political dominion so indirectly and with so many qualifications that it could not and would not arrest the growth of theoretically equal and sovereign states throughout Europe. Such state constituted potentially an international society within which real international law could develop. 
It was, in fact, the Catholic Church which laid and blessed the corner-stone of modern international law. A famous Spanish churchman early in the seventh century, Saint Isidore, archbishop of Seville, in his great encyclopedic work popularly called "The Etymologies" reserves the term ius gentium for what we should now describe as international law, so that here for the first time we find that term fairly translatable by "law of nations." All the remaining matter of the ius gentium of the Roman jurists, namely, the law common to all nations (ius commune omnium nationum), he incorporates in ius naturale. In other words, Isidore of Seville distinguishes clearly between the ius naturale and the ius gentium. The latter, he says, has to do with "the occupation of territory, the building and fortification of cities and castles, wars, captivities, enslavements, the recovery of rights of postliminy, treaties of peace and others, the scruple which protects ambassadors from violence, and prohibitions of marriage between persons of different nationality."

Isidore's definition of ius gentium and his distinction between "natural law" and the "law of nations" were of lasting importance, because they were accepted by his numerous later commentators and in the twelfth century were incorporated in Gratian's great code of canon law. Henceforth they were truisms of ecclesiastical jurisprudence.

In numerous ways the Catholic Church contributed in the Middle Age to the development of international law. Aside from sanctioning Isidore's distinctions and definitions, the Church performed a peculiarly significant service by her constant efforts to curb private warfare and to impress upon the minds of her children the value of law and of peaceful methods of settling disputes. The pax ecclesiae, which as a definite institution is first heard of at three ecclesiastical synods held in different parts of southern and central France in 990, was intended to lessen the evils of private warfare by placing non-combatants under the special protection of the Church; it forbade, under pain 
of excommunication, every act of private warfare or violence against ecclesiastical buildings and their environs, and against certain classes of persons, such as clerics, pilgrims, merchants, women and peasants and against cattle and agricultural implements. The pax ecclesiae speedily spread throughout France and Burgundy, and diocesan leagues began to be organized for its maintenance. The bishop or count on whose lands the peace was violated was vested with judicial authority, and was directed, in case he was himself unable to execute sentence, to summon to his assistance the laymen and even the clerics of the diocese, all of whom were required to take a solemn oath to observe and enforce the peace.

\section{III}

THE TRUCE OF GOD, CHIVALRY, PAPAL AMBASSADORS

A most interesting supplement to the pax ecclesiae was provided in the eleventh century by the formulation of what is known as the Truce of God. In IO27 at the call of their bishop a synod of local clergy and laity met in the country of Roussillon, in the Pyrenees, and agreed that no man should assail another on the Lord's Day. In I040 a larger assembly of prelates and nobles, under the presidency of the archbishop of Narbonne, extended the truce from the Wednesday evening to the Monday morning of every week, as well as during the seasons of Lent and Advent, the three vigils and feasts of the Blessed Virgin and those of the Twelve Apostles and a few other saints. The Truce of God in this form was decreed for Flanders in 1063, was introduced into Germany in 1082, and was instituted in southern Italy in 1089. In 1095 Pope Urban II decreed it for all Christendom, adding a guarantee of safety to all who might take refuge at a wayside cross or at the plough. The Truce of God was reaffirmed by many councils, such as that held at Rheims 
by Pope Calixtus II in I I I9, and the Lateran Councils of I I23, I I 39, and II 79.

The means employed for enforcing the Truce of God remained essentially the same: spiritual penalties, such as excommunication, special ecclesiastical tribunals, sworn leagues of peace, and assistance from the temporal power. Pope Urban II, for example, prescribed that the oath of adherence to the truce be taken every three years by all men above the age of twelve, whether noble, burgess, villein or serf.

Of the pax ecclesiae in general, and of the Truce of God in particular, the direct results were disappointing. For not only was the diocesan militia always very imperfect, but feudal society, so long as it retained political power, was inherently hostile to the principle and practice of private peace. The indirect results, however, cannot be overestimated. For what in this sphere the Church failed to do itself, it eventually inspired the rulers of the several states to do, and "ecclesiastical peace" proved to be the forerunner and prerequisite to "royal peace." The provisions of the Truce of God were often incorporated verbatim in municipal and district statutes, such as the laws of Barcelona (I067). In I085 Henry IV approved the extension of the truce to the Holy Roman Empire, and in the following century imperial laws prohibited private warfare altogether. In I257 Saint Louis forbade all private wars in his French lands.

Not only by the Truce of God, which during these centuries the Church endeavored to impose upon the bellicose feudal barons, but in the realm of justice also, a like influence was exerted both by precept and example. In the courts of the feudal lords, the judgment of God was sought by the trial of battle, where litigants, witnesses, and judges decided the case by some form of physical combat. But in the ecclesiastical courts, justice was determined by the methods and prescriptions of the canon law, which always relied upon reason and equity. And here again, prior to the revival of Roman law in western 
Europe, the canon law of the Catholic Church must be credited with inspiring and fostering the growth of royal justice and royal law.

Hand in glove with the Truce of God and with the Canon Law went the Catholic teaching of chivalry and the Catholic preaching of the Crusades. While the Church was using its authority and example to ameliorate the abuses of private warfare in Europe, it was elevating and consecrating the power of the sword by means of the crusades and the spirit of chivalry. "By its protection of the helpless and innocent, which was made the ambition of the Christian Knight, chivalry was at the same time ennobling the practice of arms and preparing the forces which were to overthrow feudalism as a social institution. The recognition of the rights of the humble, the association of the crusaders in a common cause, the formation of codes of honor, the emancipation of men from feudal obligations as a reward for their heroic deeds, the return to their places of origin of a new class of free men, were all to constitute a new leaven for the reorganization of society. A new spirit, more refined and more enlightened, was borne back to feudal Europe from the battlefields of Asia." (Hill, History of Diplomacy, I, 27 R) The Crusades which made war a weapon of common defence rather than an instrument of mutual destruction, tended in conjunction with the operation of the canon law and the pax ecclesiae, to supplant the reign of force by a reign of law.

It was not alone in securing the supremacy of law or in laying the foundation for international law, that the Catholic Church of the Middle Age performed most signal services. Diplomacy, too, owes much to the Church, especially to the Papacy. From early times it became customary for the pope to despatch special envoys (legati) from Rome to attend ecclesiastical councils or to investigate conditions in outlying provinces, and as time went on and the papacy found itself compelled to assume certain political and judicial powers, its legates discharged 
political, as well as strictly ecclesiastical, functions. In view of the special importance attaching to the relations between the Papacy and the Byzantine Empire, particularly after the Teutonic invasions, the popes maintained more or less permanent ambassadors at the imperial court at Constantinople, who were called apocrisiarii or responsales. The first of these apocrisiarii seems to have been Julian, Bishop of Cos, accredited by Saint Leo the Great to Emperor Marcian (450-457). Thenceforth for three centuries, until relations between Rome and Constantinople were severed on account of the iconoclastic troubles, there were always, apart from a few brief intervals, papal apocrisiarii at the Byzantine court. The pope likewise maintained a permanent apocrisiarius at the court of the exarch at Ravenna; and in turn, at least during the reign of Gregory I, the archbishop of Ravenna had a special responsalis at the papal court. That the procedure and etiquette attending the diplomatic intercourse of the Byzantine Emperors with other rulers throughout the Middle Age, owed much to ecclesiastical influence, is clearly demonstrated on the pages of that curious manual and guidebook De ceremoniis-a monument in the history of diplomacy-which the Emperor Constantine VII (Porphyrogenetus) dictated in the tenth century.

Throughout the later middle ages the popes frequently sent special ambassadors (legati a latere, if they were cardinals; legati missi, if they were below cardinalitial rank) to the Holy Roman Emperor and to the kings of England, France, Castile, Aragon, Naples, Hungary, etc. Although these ambassadors were sent for particular ecclesiastical purposes, the monarchs to whom they were accredited gradually adapted the practice to their own ends. In diplomacy, as in the establishment of law and the suppression of private war, the European states profited by the example of the Catholic Church. 


\section{IV}

THE CATHOLIC IDEAL OF UNIVERSAL PEACE

Midway in the Middle Age-let us say in the twelfth century-one might have been justified in concluding, from what has been said, that a most promising international society was taking form under the auspices of the Catholic Christian Church. Tribes were becoming crystallized into nations. Nations were becoming consolidated as independent and sovereign states under kings. The kings, in concert with the ecclesiastical authorities, were building up, within their respective dominions, a system of law and justice, and were curbing private welfare. Among the new states, moreover, commercial and diplomatic intercourse was developing, and already there existed the embryo of an international federation, a league of free Christian nations. For such a league the groundwork was prepared in the community of national interests provided by the common Catholic faith and by the universal similarity of institutions and methods throughout Christendom, in the great co-operative enterprise of the Crusades, and in the growing practice of submitting international disputes to papal arbitration.

It is, from my standpoint, a tragedy of the Middle Age that on this groundwork no superstructure of an effective international league was reared. The tragedy, as I conccive it, or the simple failure, as we can all agree to call it, may be explained fairly easily. It is traceable to three major facts.

In the first place, it should be borne in mind that the Catholic Church of the Middle Age, as of antiquity or of modern times, was primarily a spiritual and moral teacher. Only incidentally did it concern itself with political and economic and international questions. If it had devoted itself as insistently to political science and public law as to moral and dogmatic theology, it might conceivably have accomplished as much in fashioning a League of Nations as in Christianizing and civilizing barbarous Teutonic 
tribesmen. But such was not the commission which the Catholic Church received from its Divine Founder. Under the circumstances it is astonishing that the contributions of the Church and the Papacy to international relations and diplomacy were as great and lasting as they were, rather than that they were not greater still. When one recalls the primitive and warlike nature of the European peoples with whom the Church had to deal at the beginning of the Middle Age, and when one remembers that throughout the whole period there were no railways or steamships or telegraphs or telephones and only a few good roads and a most imperfect postal system, one can appreciate how miraculous would have been the creation at that time of an effective League of Nations. That sort of miracle did not occur, even in an age of faith.

Secondly, the tendency of the Teutonic tribes to become national independent states, theoretically equal, and the contemporaneous tendency of the Catholic Church to serve as a cement holding these national states together, were alike impeded by the surviving concept of universal secular dominion, especially by the pretensions and ambitions of the Holy Roman Emperors. In particular after the revived study of the Roman Law in the twelfth century, the old imperial notions were resuscitated and exploited by persons who were seeking to undermine the popular foundations of national monarchy or to abridge the customary rights of the Church. It was this spirit, for example, which induced the Emperor Frederick Barbarossa in I I 58 to reaffirm as his cardinal principle the dictum of the Roman Civil Law that Quod principi placuit legis habet vigorem. It was unnoted at the time that the pretensions of Frederick Barbarossa not only were in contradiction to both the Teutonic and ecclesiastical traditions, but were even in excess of the powers which, in strict legality, had belonged to the ancient Roman Emperors, for those powers had been limited by the theory in back of the Roman Civil Law, that the emperors' authority was ultimately derived from the people. 
In general contention for the new imperial claims as against those of the pope or of the national monarchs, many celebrated medievalists employed tongue and pen. Among their number were Dante (1265-1321), Marsilius of Padua (c. I270-c. I342), and William of Ockham (c. I280-c. I349). The Church and the Papacy did not lack defenders, but the ecclesiastical champions, such as Bernard of Clairvaux ( I090-I I 53), Augustinus Triumphus (d. I328), and Aegidius Romanus (c. I247-1316), were so obsessed by the controversial spirit that sometimes they grossly overstated papal ambitions. But it was in action as well as in words that the struggle between popes and emperors was joined. Developing under Pope Gregory VII in the eleventh century, it raged almost continuously during the twelfth and thirteenth centuries and far into the fourteenth. An Innocent III, a Boniface VIII, and a John XXII, labored to secure a vast theocratic federation on the one hand, while on the other a Henry VI, a Frederick II, and a Louis IV, endeavored by every means at their disposal to erect a world-dominion to which church and nations alike would be subjected.

The Emperors failed dismally in their conflict with the Popes. Thanks to ecclesiastical opposition, Europe was saved from a return to Caesarism; and the Holy Roman Empire endured only as a shadowy bond of union for the German nation. But the Papacy had to pay dearly for its victory. It had to pay with exile from Rome, with the "captivity" at Avignon from I309 to I377, with a great schism from 1378 to $14 \mathrm{I} 7$, and with resulting loss of influence and prestige. And the protracted struggle between emperors and popes powerfully aided the citystates of Italy and the national states of western Europe to consolidate each its own power, and to repudiate not only any world-dominion on the part of a Holy Roman Empire, but any theocratic federation of Christendom which the Catholic Church might champion.

Herein is to be sought the third major fact which militated against the fruition of earlier medieval dreams. It 
is the intensification of nationalism and national exclusiveness. In the fourteenth and fifteenth centuries both the city-states of Italy and the national monarchies of Western Europe evolved in the direction of jealous exclusiveness and autocracy. The development of vernacular languages and literatures and the invention of printing served to render people in a given country conscious of what was peculiar to themselves rather than of what was common to all peoples throughout Christendom. At the same time improved means of communication and the introduction of firearms enabled monarchs to centralize their administrations and to consolidate their realms. The era of absolutism was approaching.

But still the surviving concept of imperialism bore fruit. For Italian city-states were no sooner freed from foreign domination than they reached out, like Venice, to establish by force of arms an empire in Greece and in the East; and the national monarchies of the West were no sooner consolidated at home than the kings utilized their augmented resources to wage wars of aggrandizement against fellowmonarchs. An illustration of the change which had come over European minds in this connection is afforded by pamphlets of that French lawyer and reforming "crank," Pierre Dubois, who lived in the first part of the fourteenth century. Dubois had in mind the truly medieval purpose of recovering the Holy Land from the Mohammedans, and for this purpose he urged the cessation of war within Christendom and the co-operation of all Christian peoples. But he departed fundamentally from earlier medieval ideas when he advocated as head of his league and leader of his crusade neither the Pope nor the German Emperor, but the king of France. French princes were to be seated on the thrones of Europe and the East; the Church was to be secularized and subordinated to the state; and France was represented as divinely chosen to execute God's will in exterminating the infidel, in reforming the papacy, and in bestowing peace upon the world. The federation of nations and the Crusades themselves 
were to be undertaken for the greater glory of France. This is fierce nationalism; this is rampant imperialism. It is essentially modern, not medieval.

Feudal warfare practically ceased in the fourteenth and fifteenth centuries, but international and inter-imperialistic warfare took its place. To the cessation of the former the Catholic Church had contributed potently. Against the rise of the latter the Church, weakened by its conflict with the Holy Roman Empire, was now powerless to act. At the fag-end of the Middle Age appeared the European state-system, with its balance of power, its vague ius gentium, and its diplomatic usages.

\section{V}

EVOLUTION OF PROFESSIONAL DIPLOMACY

Professional diplomacy was one attribute of the new order of international society which the close of the Middle Age ushered into Europe. There had been embassies and negotiations, of course, throughout the entire Middle Age, as in ancient times, but the embassies in the main had been only temporary missions directed to a particular end and conducted by ecclesiastics or nobles of a dignity appropriate to each occasion; these were neithe permanent diplomatic agents nor a professional diplomatic class. So long as Europe was predominantly feudal, there was little room for diplomacy.

In northern and central Italy, however, feudalism had never taken root and in the struggles of the peninsula diplomacy had early played a part as important as war. There had been alliances and counter-alliances, veritable balances of power, so that medieval Italy anticipated in miniature the modern state-system of Europe. As the Italian cities increased in wealth and importance as a result of their growing commerce with the East during the later Crusades, their diplomacy waxed more significant and the diplomatic career became correspondingly more honorable and more attractive. In the thirteenth 
and fourteenth centuries Florence counted among her envoys Dante, Petrarch, and Boccaccio, and subsequently could boast of agents such as Guicciardini and Machiavelli. Papal Rome, too, continued to be, as in earlier centuries, a nursing-mother of diplomatists. But in medieval Venice the immediate origins of modern secular diplomacy are to be sought.

Venice occupied a strategic position in respect of the Byzantine Empire, the city-states of Italy, and the countries of western Europe. From Constantinople undoubtedly the Venetians learned much of the conduct of diplomatic missions, and as early as the thirteenth century the Republic began to lay down a series of rules for the guidance of its ambassadors. In 1236 envoys to the court of Rome were forbidden to procure a benefice for any one without the approval of the Doge. By a law of r268, an ambassador was not allowed to be accompanied by his wife, lest she divulge his business, but he was required to take his own cook, lest he be poisoned. By another law of the same year, any present received from a foreigner was required to be deposited with the state, until the envoy's return from his mission. No diplomatic agent was sent into a foreign territory where he had property, nor was he allowed a single day's absence from his post. In 1288 , it was decreed that ambassadors should deposit, within fifteen days of their return, a written account of the replies made to them during their mission, together with anything they might have seen or heard to the honor or in the interests of the republic. This decree, renewed in 1296 , I425, and 1533 , was the origin of the famous reports of the Venetian ambassadors to the Senate, which now constitute a store-house of information for the historian of the Renaissance and the Reformation.

In the thirteenth century, two or three months were considered a very long period for an ambassador to reside at a foreign court. In the fifteenth century Venice extended the period of an embassy to two years, and in the sixteenth century to three years. The first known instance 
of a permanent embassy was that established at Genoa, in 145.5, by Francesco Sforza, duke of Milan. Thenceforth a regular diplomatic service developed rapidly throughout Christendom. For example, in 1460 , the duke of Savoy sent a permanent envoy to the papal court ; in I 494 Milan is already represented by a permanent ambassador at the French court; and in 1496, Venice is similarly represented both in England and at the court of the Emperor Maximilian.

The art of diplomacy, developed by Venice and other Italian cities in the later middle ages, was eagerly seized upon by those monarchs of western Europe who were zealously undertaking, at the close of the fifteenth century and the beginning of the sixteenth, to consolidate and aggrandize their national states-Louis XI of France, Henry VII of England, and Ferdinand and Isabella of Spain. These monarchs practiced statecraft unburdened by the weight of too many conscientious scruples. By hook or by crook they willed to increase their personal power and to extend the frontiers of their states. If diplomacy failed them, they went to war. If they were unsuccessful in war, they resorted to diplomacy. And whether in war or in diplomacy, the first instrument was stratagem and dissimulation. "To reign is to dissimulate," was the principle laid down by Louis XI, and in sending ambassadors to the dukes of Guyenne and Brittany the French king's instructions were, "If they lie to you, lie still more to them."

Twenty-five years after the death of Louis XI, Machiavelli, the Florentine historian, publicist and diplomatist, gathered in The Prince and The Discourses on Livy the principles which underlay the practice of his day; namely, that ordinary rules of private morality are not applicable to public affairs and particularly are not applicable to intercourse between states. In vain did the Pope condemn the teachings of Machiavelli (I 559). Francis I, the French monarch who allied himself in the sixteenth century now with German Protestants and now 
with Mohammedan Turks, and who was the first monarch to establish a completely organized diplomatic machinery, did most to give Machiavelli's principles a European extension. By the close of the sixteenth century diplomacy had become frankly "Machiavellian." Despite ecclesiastical protests, "Machiavellian" was generally admitted in theory as well as in practice. Etienne Dolet, who was burned for atheism in I546, in his De officio legati ( I 54I), advises ambassadors to surround themselves with close-mouthed servants, to employ vigilant spies, and to set afoot all manner of fictions, especially when negotiating with the papal court or with the Italian princes. Germonious, archbishop of Tarantaise, another precursor of Grotius, ${ }^{1}$ in his De legatis principum et populorum ( 1627 ), after a vigorous denunciation of lying in general, argues that special lies are permissible for the safety or convenience of princes.

The Protestant Revolution of the sixteenth century and the consequent disruption of Christendom split and weakened the one force which might possibly have offered resistance to rampant nationalism, greedy imperialism, and immoral diplomacy. With the revolt of northern Europe against the Papacy and the Catholic Church, the last bulwark of medieval internationalism went down in ruins, and there arose full-grown in its stead the state-system of modern Europe with all its faults and all its vices. The events of the fifteenth and sixteenth centuries brought into bold relief the truth, as Mr. David Jayne Hill puts it, "that, as in the constitution of single states the dissolution of monarchy presents no other alternative than anarchy or self-government, so in the relations of independent sovereignties, war and diplomacy become the inevitable substitutes for empire" (Hill, I I 58). When the Holy Roman Empire failed to exercise a general secular dominion, as it failed in the fourteenth century, and when the Papacy was no longer universally recognized as a tribunal of last resort, as befell in the sixteenth century,

${ }^{1}$ For discussion of Grotius, see Appendix. 
the security of nations henceforth became wholly dependent upon armed force on the one hand, or upon intelligent association for mutual safety upon the other. Unhappily for modern Europe, the aspiration after territorial aggrandizement became the passion of the greater states at the very moment when the Catholic Church, the traditional guardian of peace and international comity, was least able to defend the rights and liberties which it had sought to protect. Intelligent association for mutual support was accordingly pushed into the limbo of forgotten dreams. And international war has loomed larger than international peace in the annals of modern history.

CARLTON J. H. HAYES. 



\section{The Development of Modern Diplomacy}





\section{THE DEVELOPMENT OF MODERN DIPLOMACY}

I

\section{POPULAR CONCEPT OF DIPLOMATS AND DIPLOMACY}

We are all more or less familiar with Sir Henry Wotton's definition of an ambassador as "an honest man, sent to lie abroad for the good of his country." This famous jest, looked upon as an indiscreet revelation of the truth, was written by the British Ambassador to Venice, in an album of a friend, in the Year of Grace 1604. It cost the witty diplomat his post, and has tended not a little to the discredit of diplomacy.

The ambassador does not stand or "lie" alone, as Wotton would no doubt have put it. "To lie like a physician" is a well-known charge in Latin as well as in English, and we of the law are frequently reminded of the epitaph intended no doubt as a compliment in a special case, but applied generally and humorously to a class: "Here lies an honest lawyer". The doctor and the lawyer may object to the company which the proverb makes them keep. The ambassador, however, given the suspicion in which he is held, may well be content to associate upon a footing of equality with these worthies, for in the popular mind he is and always has been primus inter pares.

And yet it is only fair to say of each and of every group of persons forming a class or profession, that they are not only the outgrowth of their day and generation, but that they represent the standard of their times and that they are as they are because that standard makes or allows them to be so. An ambassador who represented a Court in the Middle Ages or in the last few hundred years is not to be blamed if his standard is not higher than that of the Court whose servant or agent he is. In 
the natural course of things we can not expect water to rise above its level. It is better, although harder, to disinfect the source than to criticise the stream.

We are attracted by virtues or defects, particularly the latter, that strike the eye of the careless observer. Most of us do not take the time or the trouble to look below the surface of things. An ambassador, we say, is a useless sort of person because, like the mole, he works in the dark, or more elegantly expressed, his usefulness is hidden from the public eye. Truth is not in him, we are inclined to add, because betimes acting under instructions from his superiors, or with their approval, he goes beyond the truth, is found out and is taxed with a lie. Of course such conduct can not be justified, and yet, as long as we permit two standards. of conduct-one for the State and one for the individual-we need not be surprised if a public servant, in what he conceives to be the interest of his country, will permit himself to do and to say what no amount of pressure or profit would force him to do or to say as an individual. It is not long since that a distinguished statesman, one Bismarck by name, forged a telegram to produce a war, boasted of it in his lifetime and stated the circumstances in his Memoirs, to be published after his death.

Some say that an ambassador is an idle, frivolous person, to whom trifles are the serious things of life, because in times past he has been over-mindful of his dress and of his personal appearance, has been a stickler for precedence, and has been ostentatious beyond the standard of his critics. These are matters of form, not of substance. They are trifles in themselves, but they are not little things when States are concerned. Precedence claimed by one whose qualities do not entitle him to it is indeed foolish; precedence to the same person as the representative of a State is a different matter. In this day and generation, men of breeding give to women the place of honor, but the President of the United States and every diplomatic representative in the City of Washington assumes the 
place of honor as the representative of his country. There is a reason for most things, natural or artificial, and although we may not share it we should not deny it.

Finally, it is said that diplomacy is a failure. It does fail betimes, but its failures are known and chronicledits many successes pass unnoticed. It is, however, not too much to say that the timely intervention of the diplomat settles many a claim which might become a dispute, settles many a dispute quietly without any knowledge of it reaching the public, and that the cases which diplomacy fails to adjust are few in number and are so difficult that human ingenuity is unequal to the task, or the conflicting interests of States prevent agreement. It is only the noise that the ear notices.

\section{II}

\section{TRUE FUNCTIONS OF DIPLOMATS AND DIPLOMACY}

The truth is, the diplomat is a necessity, he is not merely an ornament, if there is to be more than one State in the world. The State, being an artificial person, can not communicate of itself with another State. It speaks by the mouth of an agent. Two States existing must come into contact. The relations external to themselves are foreign; they are international relations. And there are not two, there are many States. When intercourse was the exception, not the rule, an agent, whether he be called an ambassador or a minister, could be sent for the special occasion. When the States became numerous and their contact frequent, embassies or missions were correspondingly frequent. When it was recognized that an ambassador or a minister residing within a country permanently or for an indefinite period of time, might prevent the disputes which special missions were sent to adjust, nations began to appoint ambassadors or ministers to reside permanently in those countries with which they had most frequent intercourse. The Church was first drawn upon, as its members possessed the qualities required; then law- 
yers, in an age in which the Church was less powerful, and the relations of nations were determined according to rules of law. We thus have a class, and, the class justifying itself, we have a profession, so that today every State recognized as a member of the Society of Nations, has a diplomatic service. In the older States it is a career; in the younger States appointments are frequently made from the outside, and even in the other States, they are sometimes so made. And there will be a diplomatic service notwithstanding the fact that the minister of foreign affairs directs foreign relations and in many instances conducts them, and notwithstanding the annihilation of distance through the telegraph, and the telephone, as long as men transact their business by word of mouth and face to face. The method of conducting foreign relations may change; it has changed to meet changing conditions, but the trained man with the trained mind, in open as in secret diplomacy, in democracies as in other forms of government, will be needed, and if we are wise, will be employed and prized.

Whatever may have been the conception of diplomacy in the past, whatever criticism may have been made of its practitioners, it is today what Sir Ernest Satow, formerly an able envoy extraordinary and minister plenipotentiary of Great Britain, has declared it to be: "The application of intelligence and tact to the conduct of official relations between the government of. independent states, extending sometimes also to their relations with vassal states."

\section{III.}

THE MODERN STATE SYSTEM AND THE LAW OF STATES

Using diplomacy as "the principles of international laze applied to the relation of States", and such it assuredly is, we, in modern times, find ourselves confronted with two terms requiring consideration.

The State slowly came into being during the Middle Ages and was recognized much as it is today by the Con- 
gress of Westphalia. The law of nations slowly came into being during the same period, because, as the law of States, it pre-supposes their existence, and the modern law of nations was recognized at approximately the same time in the form and shape given to it by Grotius" in "The Lave of War and Peace" published in 1625 , that is to say, during the Thirty Years' War which the Congress of Westphalia ended.

There could be no States in the modern sense of the term when the Holy Roman Empire, which has been wittily said to have been neither holy nor Roman, claimed not merely the first place, but that all States were subordinate to and dependent upon it. There could be no States in the modern sense of the tęrm when a great spiritual organization claimed supremacy not merely in matters spiritual, but in material matters as well. Out of the conflict of these two great organizations, and from the inconsistent claims of the States of the then world, taking sides and changing sides as their interest dictated, the modern State emerged. By the Treaty of Westphalia, or of Munster (the Catholic powers negotiated at Munsterthe Protestant at Westphalia, two cities some fifty miles apart; but signed the same 24th day of October, I648) the new order of things was recognized.

For the present purposes, it is sufficient to say that a territory, large or small, with a population large or small, under a government of a monarch, prince or ecclesiastic, was recognized as a State and entitled to all the right of a State; that is to say, the State, irrespective of its origin, irrespective of its religion, irrespective of its form of government, was recognized. Primarily the boundaries of Germany were settled, and with slight changes they remained as then settled until the dissolution of the Holy Roman Empire in 1806 . The independence of Holland, long a fact, was recognized as such; the independence of the Swiss Cantons, long a fact, was likewise

${ }^{3}$ For discussion of Grotius, see Appendix. 
recognized as such. All of the European States with the exception of Great Britain, Poland, Muscovy and Turkey, were parties to the agreement, and even of these, Great Britain and Poland were considered as allies and thus were brought within the influence of the treaty. It was intended to be a universal settlement and it largely was; it was intended to be a permanent settlement and it was, for upon its foundation reposes the modern State with the modern law. of nations.

With the conflicting claims to supremacy, lay or spiritual, law was impossible, because the superior could prescribe the rule of conduct which we call law, for the inferior States according to its pleasure. The inferior States might have been equal in the sense of the Roman Law which truly and brutally says that "slaves are equal among themselves"; but they would not and could not have been equal with their superiors, and the fundamental principle of international law is the equality of right of every State with territory large or small, with a population large or small, under a government of its own choice. This law grew with and as the State; and the system of law, like the system of States, came into being approximately at one and the same time. We date both from Westphalia.

How was the system of States, and how was the system of law, to be preserved? This has been the great problem since Westphalia. It is still the problem. There are apparently two ways of solving it - one by force, the other by justice. The world has tried the first, the balance of power through force; it is beginning to try the second-the administration of justice through the instrumentalities of justice. This is a generalization, and I am aware of the witty remark of a French professor, that "all generalizations are false, including this one."

First, as to the balance of power. For whether we speak of the equilibrium of Europe, or whether we speak of the European concert, we speak in terms of the balance of power, and the principle of the balance of power 
is inevitable, unless States are organized upon some other method than power. They can only escape from it by some organization upon a different principle. We would have had the theory and practice of the balance of power in this Western World of ours had not the representatives of the States in conference assembled at Philadelphia, in 1787 , rejected size, rejected power, and formed the Union of States upon principles of justice, with appropriate agencies for its administration. Before the law all men are equal; before the law all States are equal. In the domain of justice there is neither large nor small, powerful nor weak. There are only equals in right, equals in duty, and the rights and duties are not determined by the sword, but weighed in the balance of justice. Will the world ever take America seriously?

\section{IV.}

THE BALANCE OF POWER-ITS NATURE AND APPLICATION

If the world consisted of but a single State, there would be no external questions and there would be no question of the balance of power. If the world were composed of two States, they would have disputes, but they would not dispute as to the balance of power. If there were three States coming into contact, they might and they would. With every addition to the States, the balance of power would become more pressing and more complex. Alliances would be formed to maintain it, war would be made to re-create it. The principle is apparently as old as the first three States.

What is this principle and how is it applied? Let Hume answer the question. In his Essays-Moral, Political, and Literary, published in 1752 , he speaks of the balance of power, asking "whether the idea of the balance of power be owing entirely to modern policy, or whether the phrase only has been invented in these later ages?" The answer which he gives, supported by an unfortunate 
wealth of illustrations, is that the idea was ancient and that the phrase only was modern:

In all the politics of Greece, the anxiety, with regard to the balance of power, is apparent, and is expressly pointed out to us, even by the ancient historians. Thucydides represents the league, which was formed against Athens, and which produced the Peloponnesian was, as entirely owing to this principle. And after the decline of Athens, when the Thebans and Lacedemonians disputed for sovereignty, we find, that the Athenians (as well as many other republics) always threw themselves into the lighter scale, and endeavoured to preserve the balance. They supported Thebes against Sparta, till the great victory gained by Epaminondas at Leuctra; after which they immediately went over to the conquered, from generosity, as they pretended, but in reality from their jealousy of the conquerors.

Such was the practice of the Greeks. The principle upon which they relied is stated by Hiero, King of Syracuse, who, although an ally of Rome, sent assistance to the Carthaginians during the war of the auxiliaries:

"Esteeming it requisite," says Polybius, "both in order to retain his dominions in Sicily, and to preserve the Roman friendship, that Carthage should be safe; lest by its fall the remaining power should be able, without contrast or opposition, to execute every purpose and undertaking. And here he acted with great wisdom and prudence. For that is never, on any account, to be overlooked; nor ought such a force ever to be thrown into one hand, as to incapacitate the neighbouring states from defending their rights against it."

Upon this statement of principle Hume himself says, and rightly: "Here is the aim of modern politics pointed out in express terms." And here are some examples of it in modern politics: In the Sixteenth Century, the House of Hapsburg as King of Spain, with its vast dominions, and as Holy Roman Emperor, lay heavy upon the world and threatened to crush it. Francis I of France, drawing 
upon the Eastern World, as Canning undoubtedly would have put it, to redress the balance of the Old,--meaning Europe, concluded a Treaty with Turkey to make headway against the House of Hapsburg. It was checked, but it was not humbled. It was still a menace.

The partition of the empire which took place upon the abdication of Charles V, of Germany, of Charles I, as he also was of Spain, simplified the problem. A branch of the House of Hapsburg, however, had the empire which had become hereditary in the family; a branch of the House of Hapsburg had the Spanish dominions. The Treaty of the Pyrenees of 1659, between Spain and France, left Spain indeed a factor, as the Treaty of Westphalia had left Austria and the Empire a factor, but not a menace as of other days. A new sun had arisen, and so conscious of its power that the monarch of this new menace called himself Le roi soleil. Louis XIV of France, for the reference is to him, sought to wield the sceptre which during the centuries has fallen from the grasp of world conquerors. $\mathrm{He}$ sought to overrun and to annex the Spanish provinces now forming the kingdom of Belgium. He sought to annex Alsace, in which he succeeded and to extend his domains to the Rhine, in which he failed in large part. Wherever he turned, a coalition to preserve the balance of power faced him, and eventually broke his haughty spirit. Had he thought less of his family and more of France, he could have rounded out his domains with the consent of the Powers of that day, without disturbing what they would have considered under the circumstances, the balance of power. He married Maria Theresa, daughter of the otherwise childless King of Spain, and renounced the Spanish throne for their offspring, on condition that the dowry should be paid. It never was.

The situation was simple. The Spanish monarch did not want the dismemberment of Spain. Louis XIV wanted Spain for a descendant and was more than willing to accept for himself certain portions of the inheritance. 
Europe was as unwilling to have the Crowns of France and Spain united as it had been to have the Crowns of Austria and Spain united on the same head. To prevent this a Treaty of Partition proposed by Louis XIV was signed at The Hague in 1698, between France and the then maritime Powers, England and Holland, by which, to quote Mr. Wheaton, "Spain, the Indies, Belgium and Sardinia were assigned to the electoral prince of Bavaria; the kingdom of Naples and Sicily, the Spanish places and islands upon the coasts of Tuscany, the marquisate of Final, and the province of Guipuzcoa, to the Dauphin of France; and the Milanese to the Archduke Charles."

The King of Spain, Charles II, resented this attempt to dispose of his dominions while he was still living, and made a will by which he appointed the Electoral Prince of Bavaria his universal heir, hoping to preserve the integrity of the Spanish monarchy at the expense of the German branch of his own house. However, the Prince of Bavaria died, upsetting the plans alike of France, England, and Holland on one hand, and Charles II of Spain, on the other. Therefore, a second Treaty of Partition between the same parties was concluded in I700, by which the Archduke Charles was substituted for the Prince of Bavaria who had previously died, in the inheritance of Spain, the Indies, Belgium and Sardinia. The Dauphin of France received the spoils under the first treaty, to which were added for good, or rather for better measure, the duchies of Lorraine and Bar. But Charles II of Spain was again dissatisfied and for the same reasons. He therefore made a second will, this time in favor of the Duke d'Anjou, grandson of Louis XIV and grandson of his own daughter, Maria Theresa. Charles II had no male heirs, hence the treaties of the European Powers, hence his own testaments.

But again the unexpected happened. The Holy Roman Emperor Joseph I died without male heirs, and his brother, the Archduke Charles, succeeded him. If the second Treaty of Partition should stand, the German branch of 
the House of Hapsburg would unite Austria, the Empire, and the Spanish dominions under his scepter. The result of it all was a change of front, the Partitioners accepting as the lesser of the two evils, the grandson as the King of Spain, with, however, the express provision that the Crown of Spain should never be united to that of France. Louis XIV had been so worsted in the war that he was glad in his old age to accept and to retain the kingdom of France, somewhat enlarged indeed by his previous conquests, but shorn of the conquests which he had hoped to make. The Spain of the grandson likewise suffered. Belgium, Milan and Naples were severed from the Spanish monarch and settled upon the house of Austria.

"The peace of Utrecht," Mr. Wheaton says, "was for France what that of Munster had been for the house of Austria." It was unfortunate for France, perhaps it was unfortunate for the world, that Louis XIV accepted the throne of Spain for his grandson, instead of contenting himself with the spoils of Partition which the Powers of the day were willing to accord him. The French historian, Mignet, with whom impartiality was a religion, with accuracy as a necessary consequence, has shown in the introduction to his edition of the Documents Relating to the Spanish Succession, that Louis XIV not only violated the faith of treaties in accepting the Crown of Spain for his grandson, but that he departed from all sound rules of policy. "Louis XIV had," to quote Mignet, "to choose between a Crown for his grandson or an aggrandizement of his domains maintained by Europe; between the expansion of his system in the Pyrenees and the Alps by the establishment of a branch of his house in Spain and in Italy, and an expansion of his own proper Power: between the honor of the royalty and the advantage of his kingdom; between his family and France."

Just as the treaty of Westphalia was renewed and confirmed in every treaty of peace between the Central States of Europe until the French Revolution, so the Treaties 
of Utrecht were renewed and confirmed in every successive treaty ' of peace between the great continental and maritime powers until the Peace of Luneville, in I800. It was omitted for the first time in the Peace of Amiens, concluded in 1803 , when a new and a greater sun had arisen upon the political firmament.

Such is the practice of Europe. What was the theory by which it was justified? Let one of the greatest masters of international law answer the question, just as an appeal has been made to Hume, a noted philosopher.

In his Law of Nations, published in 1758, Vattel has this to say:

It is asked whether the aggrandizement of a neighboring State, in consequence of which a Nation fears that it will one day be oppressed, is a sufficient ground for making war upon it; whether a Nation can with justice take up arms to resist the growing power of that State, or to weaken the State, with the sole object of protecting itself from the dangers with which weak States are almost always threatened from an overpowerful one.

This just man felt that the question presented difficulties of a perplexing nature to "those who seek at all times to unite justice with prudence," but that it presented "no difficulties to the majority of statesmen." His answer to the question "whether war may be maintained for this purpose" is that

Since war is only permissible in order to redress an injury received, or to protect ourselves from an injury with which we are threatened, it is a sacred rule of the law of nations that the aggrandizement of a State can not alone and of itself give any one the right to take up arms to resist it.

But he did not stop with this statement. He went further, saying:

As soon as a State has given evidence of injustice, greed, pride, ambition, or a desire of domineering over its neighbors, it becomes an object of suspicion which they must guard against.

He next puts the pertinent question which is indeed the 
crux of the matter: "Are we to delay averting our destruction until it has become inevitable?" And in this connection he refers to a familiar illustration:

Had Charles II, King of Spain, instead of settling the succession upon the Duke of Anjou, appointed Louis XIV himself as heir, had he thus tamely suffered the union of the House of Spain to that of France, it would have meant, according to all the rules of human foresight, nothing less than delivering all Europe into servitude, or at least putting it in a most precarious condition.

\section{He next asks :}

If an unknown man takes aim at me in the middle of a forest, I am not yet certain that he wishes to kill me; must I allow him time to fire in order to be sure of his intent? Is there any reasonable casuist who would deny me the right to forestall the act? But presumption becomes almost equal to certitude if the Prince who is about to acquire enormous power has already given evidence of an unbridled pride and ambition. In the imaginary case mentioned above, who would have dared counsel the European states to allow Louis XIV to make such a formidable addition to his power?

Vattel now speaks as a man "zwo seeks at all times to unite justice with prudence," and resolves the doubts which he has raised in the series of questions which he has put; he supposes that the powerful State is both just and prudent in its conduct, and he asks if, under such circumstances, we should idly look upon its rapid increase of power and lay ourselves open to the designs which it may seek to realize.

The example of the Romans is a good lesson for all sovereigns. If the most powerful States of that day had united together to watch over the movements of Rome, to set limits to her progress, they would not have successively become subject to her.

However, Vattel as a lover of justice and prudence did not advocate force in first instance:

"There are gentler means, which are always lawful. The most efficacious of these is an alliance of other less 
powerful sovereigns, who, by uniting their forces, are enabled to counterbalance the sovereign who excites their alarm." This could be accepted by all the states of his day.

"Europe forms a political system in which the nations inhabiting this part of the world are bound together by their relations and various interests into a single body. . . The constant attention of sovereigns to all that goes on, the custom of resident ministers, the continual negotiations that take place, make of modern Europe a sort of Republic, whose members-each independent, but all bound together by a common interest - unite for the maintenance of order and the preservation of liberty."

"This," he adds, "is what has given rise to the wellknown principle of the balance of power, by which is meant an arrangement of affairs so that no State shall be in a position to have absolute mastery and dominate over the others."

To maintain the balance, "no State should be much superior to the others", and "all the States, or at least the larger part, should be about equal in strength." How can the balance be preserved? As it was impossible, he recognized, to trim the States so that they would be approximately equal, nations would have to rely upon alliances - the method of Europe, he said, "at the present day", or a method soon to be tried, and now again on trial. "Confederations would", in his opinion, "be a sure means of preserving the balance of power and thus maintaining the liberty of nations, if all sovereigns were constantly aware of their true interests, and if they regulated their policy according to the welfare of the State."

This may be said to be the language of the theorist, although Vattel was a diplomat by profession, speaking from experience and with a knowledge of practice. However, Count Kaunitz, Chancellor of Austria, was certainly a man of affairs and in his circular note of July I7, r79r, he advocated that the Powers make common cause against the French Revolution for the purpose of 
preserving "public peace, the tranquillity of States, the inviolability of possessions, and the faith of treatics."

THE BALANCE OF POWER IN MODERN TIMES-THE HOLY

\section{ALLIANCE}

It is immaterial to present purposes whether the wars of the French Revolution were provoked by Europe or were declared by France. The victory of French arms brought with it an aggressive policy. The generous ideas of the first days spent themselves. Bonaparte mastered the Revolution, and he set about to master Europe. He succeeded for the time, but he ultimately went the way of the world conquerer. Coalition after coalition was formed to prevent the aggrandizement of France, and in the end, they were successful. The victors met at Vienna in the course of I8I4 and I5, just a century after the Congress of Utrecht, and almost a hundred years before the Conference at Paris. Austria, Great Britain, Prussia and Russia set about the reconstruction of Europe. The victim was at first excluded from their councils, but the skill of Talleyrand opened the door of the Council Chamber to France. These five Powers proceeded to redress the balance and Alexander of Russia, in language which sounds strangely familiar to us of the present, argued that the outcome of the war was to be not only the liberation of France, but the universal triumph of "the sacred rights of humanity." "To attain this it would be necessary "after having attached the nations to the greatest interests of their subjects, to fix the relations of the states amongst each other on more precise rules, and such as it is to their interest to respect."

A general treaty was to form a basis of the relations of the States composing the "European Confederation," and although "it was no question of realizing the dream of universal peace, would attain some of its results if, at the conclusion of the general war, it were possible to es- 
tablish on clear principles the prescriptions of the rights of nations."

And in both the form of question and answer, which sounds but of yesterday, the Autocrat of all the Russias continued:

"Why could not one submit to it the positive rights of nations . . . insert the obligations of never beginning war until all the resources which the mediation of a third party could offer have been exhausted, having by this means brought to light the respective grievances, and tried to remove them? It is on such principles as these that one could proceed to a general pacification, and give birth to a league of which the stipulations would form, so to speak, a new code of the law of nations, which sanctioned by the greater part of the nations of Europe, would without difficulty become the immutable rule of the cabinets, while those who should try to infringe it would risk bringing upon themselves the forces of the new union."

Such is the origin of the Holy Alliance, drafted by Alexander I of Russia, approved in first instance by the Emperor of Austria, the King of Prussia, proclaimed on September 26, I8I 5, at a great review of the allied troops on the Champ des Vertus, near Paris. To the Treaty or Declaration of the Holy Alliance, the name of every European sovereign with the exception of the Pope, the Ottoman Empire, and Great Britain is subsequently appended.

Mr. W. A. Phillips, a leading authority on this subject, and whose masterly work on the "Confederation of Europe" issued in the first month of I9I4, was at the disposal of statesmen of that day, says:

"In popular parlance, which has found its way into the language of serious historians, the 'Holy Alliance' soon became synonymous with the combination of the great powers by whom Europe was ruled in concert during the period of the congresses, and associated with the policy of reaction which gradually dominated their counsels. For the understanding of the inner 
history of the diplomacy of this period, however, a clear distinction must be drawn between the Holy Alliance and the Grand or Quadruple (Quintuple) Alliance. The Grand Alliance was established on definite treaties concluded for definite purposes, of which the chief was the preservation of peace on the basis of the territorial settlement of 1815 . The Holy Alliance was a general treaty-hardly indeed a treaty at allwhich bound its signatories to act on certain vague principles for no well-defined end; and in its essence it was so far from necessarily reactionary that the emperor Alexander at one time declared that it involved the grant of liberal constitutions by princes to their subjects. Its main significance was due to the persistent efforts of the Czar to make it the basis of the "universal union" or general confederation of Europe, which he wished to substitute for the actual committee of the great powers, efforts which were frustrated by the vigorous diplomacy of Castlereagh, acting as the mouthpiece of the British government."

We have just emerged from a great war, in which the most powerful of European States-certainly from the military point of view the most powerful State of the world-deliberately attempted to impose its domination, its culture, its conception of liberty, upon the rest of the world. This war had been foreseen. To the Triple Alliance, which included Germany, its satellite, AustriaHungary, and its questionable ally, Italy, three other Powers, France, Great Britain and Russia, opposed the Triple Entente. The assassination of the heir apparent to the throne of Austria-Hungary and his morganatic wife by a subject of that monarchy, although of Serbian race, led Austria-Hungary to incriminate Serbia, and alleging a lack of compliance with an ultimatum demanding an acceptance within forty-eight hours, Austria-Hungary declared war against Serbia on July 28, 1914, although that little country offered to submit the outstanding dispute to arbitration. Russia espoused the cause of its Slav neighbor: Germany appeared in shining armor at the side of its ally, and declared war against Russia on the 
Ist of August. On the 3rd of August, Germany declared war against France, without any aggressive action on the part of that country, invaded Luxemburg and Belgium, whose neutrality it had promised to preserve, because of which Great Britain declared war against Germany on the $4^{\text {th }}$ of August, and little by little the world was at war.

The German army rushing through Luxemburg, rushing through Belgium, in its effort to strike at the very throat of France, unprepared for an attack through these neutral countries, was checked at the Marne, on the ever memorable sixth day of September, I9I4:

"Who knows," said Duruy, writing in 1873, when his devoted country lay prostrate at the feet of Bismarck, "who knows but that the broken sword, left in our hands after a sudden misfortune, may not one day be required to defend universal liberty against brutal ambitions?" And, "France has at least," he added, "the right to remember that she succeeded three times in arresting or breaking a menacing power, that of Charles V, of Philip II, and of Ferdinand of Austria."

An armistice was accorded Germany at her own request on November II, I9I8, and the world is slowly emerging from the shadow of German domination.

The power of Prussia has indeed been broken. How is the balance of power to be restored and maintained? The Conference at Paris proposed a League of Nations which at present seems to be a military and economic alliance of the four Great Powers. Will it succeed? Posterity alone can tell.

\section{VI}

\section{THE CONTENT OF MODERN DIPLOMACY}

"Now that is an intolerable doctrine, which some authorities have handed down, that by the Law of Nations arms may rightly be taken up in order to weaken a power which is increasing and which, if increased too much, might inflict injury. I confess that in a deliberation about war this may also come into 
consideration, not from the point of view of justice, but from the point of view of utility; so that, if a war be just on other grounds, it may likewise be judged to have been undertaken prudently on this ground; and this is precisely the meaning of the authorities cited on this matter. But that the possibility of suffering violence gives the right to inflict violence, is contrary to every notion of equity. Such is human life, that complete security is never apparent to us. Protection against uncertain fears must be sought from divine providence and blameless caution, not from force."

In these words, a great Dutchman, whose name is familiar to us in its Latinized form of "Grotius", 2 pays his respects to the principle of the balance of power, and to it opposes a principle which, although not so popular, is, nevertheless, making its way in the world.

Force has been opposed to force, and force in large or small quantities has not maintained peace. It can not, unless peace is in some way connected with force, so as to emerge from the clash of opposing force. Force is material, and its fruits are material victories. Peace, we have at least learned within national lines, is the consequence of justice. It is the perfected fruit of justice, and agencies exist in abundance for the administration of justice, or at least that portion of it which we call rules of law.

Grotius states that "protection against uncertain fears must be sought from divine providence and blameless caution." Whether Divine Providence will listen to us in our distress, is not for us to determine, although we may hope for protection if we conduct ourselves in accordance with the dictates of Divine Providence. "Blameless caution" he does not define, and we need not dwell upon it. We would not be straining language if we should say that it implied having our quarrel just and then settling it by justice. Grotius himself was in favor

\footnotetext{
${ }^{1}$ Grotius, De Jure Belli ac Pacis, Lib. II., Cap. 1, Sec. 17.

${ }^{2}$ For discussion of Grotius, see Appendix.
} 
of arbitration; he was also a believer in the submission of disputes between nations to conferences of the States. Tested by its fruits, the balance of power did not seem to him to be an agency of peace. On the contrary, peace is the offspring of arbitration between nations, just as peace within nations is the inevitable outcome of judicial decision. It is often a consequence of conferences. Arb1tration developing into judicial decision, irregular conferences developing into conferences of the nations, meeting at stated periods, are the content of modern diplomacy, and are destined, as we hope, to succeed where the balance of power has failed.

I shall now ask your attention to each of these in turn.

\section{VII}

ARBITRATION-DEFINITION AND HISTORICAL APPLICATION

Probably there is no better definition of arbitrationcertainly there is none from a higher source, than that given by twenty-six nations of the world in the conference assembled at The Hague in 1899, and approved eight years later by forty-four nations, in the Second Conference of The Hague. According, therefore, to the consensus of opinion, international arbitration is, to quote the exact language of these two bodies: "the settlement of differences between States, by judges of their oren choice, and on the basis of respect for law."

Arbitration has an ancient and honorable history. In this very course of lectures you have heard to what extent it flourished chiefly among the Greek States of antiquity, and how it was resorted to in the Middle Ages. It is said to be the shield and buckler of the weak, and yet, curiously enough, the chief treaties of arbitration concluded in the Seventeenth Century were those to which Oliver Cromwell, Lord Protector of England, was a party. The first treaty of arbitration in the modern series was the Jay Treaty, concluded by the United States with Great Britain in I794, in the course of a war or 
series of wars, from which Great Britain was to emerge as the strongest of nations. And the strength of Great Britain has not declined, for in our own day, with our own eyes, we have seen it with its back to the wall, emerge from a desperate conflict stronger than ever. It is a fact that of all countries, Great Britain has to its credit more arbitrations than any other nation. The United States may have been weak in 1794, when it proposed that Great Britain and the United States should arbitrate their outstanding differences. It has grown with the years, and in its strength, as well as in the days of its weakness, it stands for arbitration, and, with the exception of Great Britain, has more arbitrations to its credit than any other nation. These two together made modern arbitration; they have been its chief practitioners, and the world has been the beneficiary. Therefore, it is not fair to say that only weak nations desire arbitration, although that would be a sufficient justification for it.

There were some powerful nations in the Nineteenth Century and in the first fourteen years of the Twentieth, who regarded it as the refuge of the weak. Germany prevented a general treaty of international arbitration from being concluded at the Second Hague Conference. Its then powerful Ally, Austria-Hungary, supported it against the opinion of the world. They tried the sword. Republican Germany and mutilated Austria, if it remains independent, will doubtless be willing to try arbitration in the future.

But to come back to Cromwell. On April 5, 1654, he concluded the so-called Treaty of Westminster, between England and the Netherlands, in which, among other things it was provided: that the losses suffered by the seizure and detention of English effects in Denmark since May 18, I652, were to be made good according to an appraisement of certain "arbitrators indifferently chosen", and, in case of a failure to adjust differences within a period of three months, they were to be submitted "to the judgment and Arbitration of the Protestant Swiss 
Cantons". An award was rendered by the Commissioners, and under the 3oth article of the same treaty, losses of the East and West India Companies were settled in the same manner. It is worth while noting, in passing, that in those days Holland was very far from a "weak" country.

Another treaty of Westminster was concluded on July Io, 1654, between England and Portugal, providing that demands on account of losses were to be referred to arbitration for settlement. The Commission was to be composed of two Englishmen and two Portuguese, and on failure to agree, the cases left undecided were to be referred to a member of the Lord Protector's Council, to be nominated by the Protector himself, and whose decision was to be final. Portugal was, at this period, a weak power, otherwise it would not have accepted such person as Cromwell should be pleased to appoint.

The case was different with the Treaty of Westminster of November 3, I655, between Cromwell, of the British Commonwealth, on the one hand, and Louis XIV, on the other. However, the two High Contracting Parties agreed, by article twenty-four, to submit to three Commissioners the legality of captures made by the two countries from I640. In case of their inability to agree, the City of Hamburg was to delegate Commissioners, whose award was to be made within four months, and was to be final.

Finally, the Treaty of Westminster, of July I $_{5}, 1656$, between Cromwell, it may be said, on the one hand and Sweden on the other, provided that three Commissioners should be delegated on each side, to adjust differences and to settle the losses arising from capture made during the war between England and the Netherlands.

It would be a waste of time to speculate what might have happened if the views of that great man had dominated the conduct of nations,-less interesting perhaps, but certainly as useless as Pascal's statement to the effect that "If the nose of Cleopatra had been shorter, the 
whole face of the earth would have been changed." Cromwell's practice was not followed, and Cleopatra's nose was -as it was.

In the last quarter of the Eighteenth Century, these United States of America came into being, and with them the doctrine that government derives its just power from the consent of the governed, and that justice should obtain between States as it does between men. The recognition of the independence of these States was contained in the Treaty of $I 783$, between Great Britain and the United States. It was alleged that neither of them lived up to their obligations under this treaty, and that acts of lawlessness were committed by each, which brought them to the verge of war. To avert this calamity, President Washington, who believed and said that all disputes between nations should be settled by peaceful means, sent John Jay, then Chief Justice of the Supreme Court, to England, to effect, if possible, a settlement. This he did, and the treaty which appropriately bears his name, provided in its fifth article for a Commission to decide which was the River Saint-Croix intended by the Treaty of 1783 . In this the Commission was successful. The sixth article provided that a Commission should deter. mine the losses suffered by British creditors because of the failure on the part of the American States to live up to the agreement of the Treaty of Peace. The Commission awarded three hundred thousand dollars, and broke up. The United States subsequently paid, in addition, a lump sum of three million dollars, in satisfaction of all these demands. The seventh article provided that the claims of Americans for unlawful capture or destruction of their property upon the high seas, committed by Great Britain during the revolutionary wars then raging, should be submitted to a commission of five, and that the claims of British subjects for a failure of the United States to protect them within their jurisdiction, or because of the failure to prevent France from making unlawful captures, should be submitted to the same commission. The various 
claims were to be decided upon their merits and according "to justice, equity, and the laws of nations". Awards were made in favor of and against each. The five Commissioners, - of whom the Chairman, John Trumball, was curiously: enough a former Colonel in the Continental Army and Aid-de-Camp to General Washington, and Mr. Jay's Secretary of Legation at the time of his appointment, and a portrait painter of repute-were so successful that they not only settled the disputes between the two countries justly, but convinced nations of the advantage of arbitration.

Since then there have been many treaties of arbitration during the course of the Nineteenth Century, there have been innumerable cases adjusted by arbitration, and in the first decade of the Twentieth Century the world was, as it were, surrounded with a net of arbitration treaties. The instrument of peace was there, but it was not a self-starter ; it needed to be set in motion. Unfortunately, it could be said of arbitration as Cardinal Fleury said to the Abbé St.-Pierre anent his plan for perpetual peace: "You have forgotten an essential article, that of sending missionaries to touch the hearts of princes and to persuade them to accept your views."

\section{VIII.}

INTERNATIONAL CONFERENCES, THE IDEAL OF SIMON BOLIVAR

To quote again the first expounder, if not the father of International Law, our friend Grotius, ${ }^{1}$ who says in his book on The Law of Nations, published in 1625, during the Thirty Years War:

"It would be useful and indeed it is almost necessary, that certain Congresses of Christian Powers should be held, in which the controversies which arise among some of them may be decided by others who are not

\footnotetext{
${ }^{1}$ For discussion of Grotius, see Appendix.
} 
interested; and in which measures may be taken to compel the parties to accept peace on equitable terms."

The remedy prescribed by the physician was tried in the Congresses of Westphalia and Munster, in I648, which put an end to the Thirty Years' War. It has also been tried on later occasions, notably in the Congress of Utrecht and of Vienna; and in a series of congresses in the Nineteenth Century, one at Paris in 1856 , ending the Crimean War, another at Berlin ending the Russo-Turkish War, and culminating in the Conference at Paris of I919. In all of these congresses or conferences, some principles of international law have been discussed, laid down, and accepted. But these principles were few in number; they were incidental, showing at most what a conference could do if it met in time of peace for this purpose, instead of meeting at the end of war. They were, however, war congresses, animated by a spirit of vengeance, in which indeed, measures were taken, to quote Grotius, "to compel the parties to accept peace". They were not, however, his kind, as the peace imposed was not "on equitable terms". Grotius evidently meant a conference meeting under circumstances when equities could be considered. Controversies between some of the nations were to be submitted and decided by these conferences, not by the parties in dispute, but by others, which were not interested. In his conception, the States of Europe were looked upon as members of a great family, or great society, or great commonwealth, or of a great republicthe term is indifferent-and because of the fact that all were affected to a more or less degree by a resort to arms, the powers affected, though not parties to the controversy, were to determine the conditions of peace upon equitable terms, because of the general, not of the specific interest. It was not to be a Congress meeting at stated terms, it was to meet from time to time, in case of need, but when it did meet and was in session, it was apparently to be an assembly which could treat a dispute of a legal nature according to rules of law, and of an equitable na- 
ture according to what would be considered just and fair. There have, unfortunately, been very few gatherings of this nature, in accordance with the spirit of his proposal. The best example was but of yesterday, when, in I884, a conference of interested Powers met at Berlin, under Bismarck's presidency, to settle the disputes between Powers claiming African territory, laid down rules of conduct for such Powers, and provided for their peaceful settlement. This Conference proved that the idea of Grotius was not Utopian, and it is perhaps not too much to say that it has kept the peace in Africa which might have been broken, and given rise to wars, as was the case for generations in the recently discovered and thinly settled tracts of America.

However, the idea which Grotius may have had in mind was more clearly expressed and brought to the attention of thinking people by one who was not, like Grotius, a writer on international law and a master of international relations. He had not held, as Grotius, the post of an Ambassador. This obscure person was from the New World. His voice was the voice of the New World; his spirit was of the New World. He was the mouthpiece of the new diplomacy and he proposed the conferences of nations to be held in time of peace, to preserve peace-to take from the large domain of justice, its principles, and to state them in rules of law for the conduct of nations. His plan has been tried and found workable, although perhaps those who called into being the conference which he advocated were unconscious that such a man as William Ladd ever lived.

What was the plan? The precedent which caused Ladd to propose his plan was American. Simon Bolivar, the Liberator of South America, as he is called, proposed a meeting of the Latin-American States, hardly out of the cradle. The meeting of their representatives was to be held at Panama. The United States was invited, and, after much controversy, our participation in the conference was authorized, but our delegates were appointed 
when it was too late. The conference failed. From the Panama incident, "The inference to be deduced," Mr. Ladd said, "is, that the governments of Christendom are willing to send delegates to any such Congress, whenever it shall be called by a respectable state, well established in its own government, if called in a time of peace, to meet at a proper place."' He was not, however, satisfied with representatives of the Christian powers. Perhaps he had doubts as to their Christianity. Ambassadors were to be appointed in addition, of "civilized nations", which might care to send them. He did not prescribe "the proper place." The Czar of all the Russias did that forty-eight years later, in $\mathrm{r} 898$. However many ambassadors or representatives a nation might send, it would only have one vote. They therefore were to meet on a plane of equality. They would discuss measures, and only such were to be adopted as all the nations should agree to, and those States only were to be bound which should subsequently ratify them. Certain subjects were not to be discussed.

"The Congress of Nations is to have nothing to do with the internal affairs of nations, or with insurrections, revolutions, or contending factions of people or princes, or with forms of government, but solely to concern themselves with the intercourse of nations in peace and war."1 What measures were to be discussed? Mr. Ladd did not leave his readers in doubt, and it will be obvious to you that he outlined the program of the two Hague Conferences.

The purpose of the conference was to settle "the principles of international law by compact and agreement, of the nature of a mutual treaty, and also of devising and promoting plans for the preservation of peace, and ameliorating the condition of man." 2 Here is his program:

1. To define the rights of belligerents towards each

${ }^{1}$ William Ladd, An Essay on a Congress of Nations for the Adjustment of International Disputes Without Resort to Arms, 1840, Edition of 1916, New York, p. 57.

'Ibid, Advertisement, p. xlix. 
other; and endeavor, as much as possible, to abate the horrors of war, lessen its frequency, and promote its termination.

2 . To settle the rights of neutrals, and thus abate the evils which war inflicts on those nations that are desirous of remaining in peace.

3. To agree on measures of utility to mankind in a state of peace; and

4. To organize a Court of Nations. These are the four great divisions of the labors of the proposed Congress of Nations. ${ }^{2}$

\section{IX.}

\section{THE HAGUE CONFERENCES}

The first of these congresses, called The Hague Conference, met in 1899 , in a time of profound peace, and did settle some of the principles of the law of nations "by compact and agreement, of the nature of a mutual treaty". It expressed itself strongly and unequivocally in favor of arbitration for the settlement of disputes, and it created the so-called Permanent Court of Arbitration, which is in reality a list or panel of judges, from which a special tribunal or commission can be appointed, whenever States in dispute may be wise enough to lay their disputes before judges of their own choice, for the decision of their controversies upon the basis of respect for law.

The second of the Conferences met at The Hague in 1907, and attempted in accordance with Mr. Ladd's fourth division, "to organize a Court of Nations." The Court was not made, but progress was. A draft convention for the so-called Court of Arbitral Justice was adopted by the Conference, with their recommendation to the Powers to agree upon a method of appointing the judges, and thus constitute it.

A Committee of Jurists met at The Hague the summer of 1920 to do this. The Council of the League of

${ }^{1}$ Essay on a Congress of Nations, pp. 10-11. 
Nations adopted their project with slight modifications, on October, 27th 1920, and the Assembly of the League of Nations adopted the project, with some changes on December I3, 1920. By rejecting the principle of compulsory jurisdiction, they reverted practically to the proposed Court of Arbitral Justice of 1907.

In one respect, this is to be regretted, as the Court of the Nations might have been constituted like the Supreme Court of the United States, in which State may sue State without a special agreement to the question in dispute which is often difficult to frame. It is unfortunate, likewise, that a nation can not, as a State of the American Union can, sue a State and obtain a judgment against the defendant even though it does not appear and answer.

However, the first step was taken in 1907, and our French friends tell us that "It is only the first step that counts". A second step was taken in 1920 , and a very long one, for an agreement was reached in the Advisory Committee and approved by the Council and the Assembly of the League of Nations, upon an acceptable method of appointing the judges. Many a step remains to be taken to supply law for the Court and to enlarge its jurisdiction. But peace can only result in this practical world of ours, from an infinite series of little steps. The nations are unwilling to make a leap in the dark. They fear, as do the sensible people of which they are composed, to fall in the ditch. Many conferences of the nations must be called to meet to take these steps. A third of The Hague series was due in I9I 5-that is to say, eight years after the adjournment of the Second, in 1907, as the nations had agreed to a third at approximately this time. But the war came instead.

Will further conferences take place? If so, when and what will be their general program? The Advisory Committee of Jurists that drafted the Court project at The Hague last summer, unanimously recommended a series of conferences to be called "Conferences for the Advancement of International Law", to meet as succes- 
sors to the first two Hague Conferences, at stated times, to continue the work left unfinished; and the Committee recommended further that the first of the series be held as soon as practicable for the purposes which they were bold enough to state as follows:

1. To restate the established rules of international law, especially, and in the first instance, in the fields affected by the events of the recent war.

2. To formulate and agree upon the amendments and additions, if any, to the rules of international law shown to be necessary or useful by the events of the war and the changes in the conditions of international life and intercourse which have followed the war.

3. To endeavor to reconcile divergent views and secure general agreement upon the rules which have been in dispute heretofore.

4. To consider the subjects not now adequately regulated by international law, but as to which the interests of international justice require that rules of law shall be declared and accepted.

If the world wants these conferences to meet at stated periods to take up the work of the world interrupted by the war and where the war left it, they may do so.

In I787, our own Benjamin Franklin wrote to a friend in Europe:

I send you enclos'd the propos'd new Federal Constitution for these States. I was engag'd 4 Months of the last Summer in the Convention that form'd it. It is now sent by Congress to the several States for their Confirmation. If it succeeds, I do not see why you might not in Europe carry the Project of good Henry the 4th into Execution, by forming a Federal Union and One Grand Republick of all its different States \& Kingdoms; by means of a like Convention; for we had many Interests to reconcile. ${ }^{1}$

We are inclined to dwell upon our rights, at the expense of our duties, which, however, our neighbors do not

${ }^{1}$ Letter of Benjamin Franklin to Mr. Grand, October 22, 1787. Documentary History of the Constitution, Vol. IV., pp. 341-342. 
always overlook. Nations which are made up of the same men and women, more or less artificially grouped, are likewise inclined to look upon their rights as free, sovereign, and independent States. We must not, however, deceive ourselves. We have rights, but they are useless unless it be the duty of others to recognize and respect them; otherwise, we would live in a state of anarchy. It is the same with nations, and for the same reasons. Therefore, a problem of the new diplomacy is to devise some form of organization,-call it a society, an association, or a league of nations, if you please-which, while recognizing the right of nations, and safeguarding them, shall at the same time, state the duties of nation to nation, to the end that we may live in an ordered world -ordered, be it said, not from above, not from below, but by the States themselves, in the exercise of their freedom, sovereignty, and independence.

Many attempts have been made to reach this goal; by men of vision, whom the world calls dreamers; by statesmen usually out of office and spending the remnant of their days in dignified retirement; latterly, by hard-headed men of affairs, with the vision of the dreamer, but without the experience of the statesmen. Persons interested in this sort of thing are familiar with the "great design of Henry IV", devised by his great Minister, Sully, living in retirement after his master's death; with Penn's "Plan of a European Diet" at the close of the seventeenth century, by which the forces of the members were to be united in one strength, and to be used against the recalcitrant bent upon breaking the peace; with the project of the good Abbe de Saint-Pierre, in the first quarter of the eighteenth century, which he, like Sully, foisted upon Henry IV, and which is a tractate on perpetual peace, which he sought to usher into a warridden world; with Kant's "Perpetual Peace", appearing during the French Revolution and during the last decade of the eighteenth century, advocating republican, that is, constitutional or representative government; with the 
Holy Alliance of Alexander I of Russia, proposing a League of Nations, the members of which were to be kept in order by armed force; and with the more modest proposals of The Hague Conferences, by which the nations regarded themselves as forming a society to be governed by justice and equity, recorded in instruments negotiated by them, and to be applied in their mutual intercourse. These projects, however much they differ, have one point in common; that all provide for a union of States, with duties as well as rights.

But I do not intend to speak of these projects or any of them. I would crave your indulgence for some closing remarks upon the one Union of States, extending over a vast area, controlling the actions of multitudes of men and women which, surviving its framers and standing the test of time, may profitably be considered when questions of international organization are discussed.

\section{$\mathrm{X}$.}

THE UNITED STATES AS AN EXEMPLIFICATION OF INTER-

\section{NATIONAL ORGANIZATION}

Thirteen British colonies of North America, from New Hampshire on the North, to Georgia on the South, declared, on July 4, 1776 , their independence by deputies duly authorized thereto and representing them at the time in that distinguished Revolutionary body known as The Continental Congress, then in session at Philadelphia. Heretofore, they had been colonies, and called themselves such; hereafter, they were States, and called themselves such. They were united, some say, in 1774, by the Articles of Association-others that they were united by the Declaration of Independence. The purpose, however, for which they were united was to secure under the Articles of Association a redress of grievances; under the Declaration of Independence, a recognition of their independence by the mother-country. The union was temporary. It 
was not satisfactory. They felt that they needed to be drawn together closer and upon a permanent basis. Therefore, a Committee of Congress drafted Articles of Association for a league of friendship, permanent in its nature, which they called the Articles of Confederation, and in the second article the States declared themselves to be, "sovereign, free and independent", and possessed of every power which they did not expressly grant to the United States in Congress assembled.

The important point to bear in mind is that these States thought themselves to be free, sovereign and independent, and therefore, they stated themselves to be such. The Articles of Confederation bound each State only from the date of its approval. The last of the thirteen States approved of them on March I, I78I, from which date there was a union in law, as well as in fact, of the thirteen American States.

The union, however, had many grave defects, the chief one being that it did not work, or at least that it did not work to their satisfaction. The farsighted among them therefore proposed a more perfect union. And what was this to consist? Of States, in place of the less perfect union of States.

For this purpose each of the States, with the exception of Rhode Island, which abstained in the exercise of its sovereignty, freedom and independence, sent delegates to meet other delegates of the States of this imperfect union, in order to make the Articles of Confederation adequate for the exigencies of the Union. They were to have met on the second Monday in May, in Philadelphia. A majority of the States were not represented until the 2.5 th, when they met. The delegates were appointed by the legislatures of the different States; they acted under instructions from their respective States. Their first act was to elect a Chairman, one George Washington, Delegate from Virginia, and a Secretary. They thereupon proceeded to examine the credentials of the different members, in order to see that they were entitled to represent 
their States for the purpose in mind. Little by little, the Delegates of all the States arrived, with the exception of Rhode Island. Twelve States were therefore represented. The Conference, called the Federal Convention, adjourned on September I7, I787, having drafted the Articles of Union which we call the Constitution of the United States.

The Delegates of this memorable assembly apparently had trouble with the Preamble, inasmuch as only twelve of the thirteen States were represented, and feared that some of the States might not ratify the instrument, for it was to be presented to each of the States to be considered by a convention in each of the States, specially called for that purpose.

The Constitution had made the ratification of nine States necessary for the government thereunder to go into effect-not for all of the States, but merely for the nine or more which might have ratified it. Two held out, and were therefore foreign States. One of these, North Carolina, came in in I789. Rhode Island toddled in in I790.

How was the Preamble to begin? All the drafts save the last reported by the Committee on Style, on Septembr 12, began with "We the People of the States of New Hampshire, Massachusetts, Rhode Island", etc., down to and including Georgia. That is to say, they enumerated the thirteen States, beginning with the most northern and ending with the most southern. Should the thirteen be included, when only nine might ratify, and when, as a matter of fact, two out of the thirteen did not, until after the Constitution and the government under it went into effect? Some clever draftsman, probably Gouverneur Morris, who was a member of the Committee of Style and Arrangement, and to whose facile pen the excellent literary style of the instrument is accredited, solved the difficulty by striking out all the names of the States, and inserting, "United" before "States", so that the Constitution, instead of reading, "We the People of the States of New Hampshire", etc., read now, reads and ever will 
read, "We the People of the United States". We should not, however, overlook the fact that it was the people of the States; it was the people of each of the States that ratified the Constitution; it is the people of each of the States that elect the members of the Senate and the House of Representatives, and it is the electors chosen by the people within each of the States who elect the President of these United States.

As that Prince of Jurists, the great Chief Justice Marshall, said in one of his greatest cases, decided in 1819:1

No political dreamer was ever wild enough to think of breaking down the lines which separate the States, and of compounding the American people into one common mass. Of consequence, when they act, they act in their States.

Because of this, their experience is valuable to people of foreign States, who also act, when they act, within their States. Each State of the American Union has two Constitutions. One is local, dealing with those matters that begin and end within the boundaries of the State. It may be amended whenever the people so desire. The second Constitution is not local, but general. It deals with matters that may begin within a State, and extend beyond it, or which arise without the States, and yet affect them, as in the case of foreign affairs. This constitution is the Constitution of the United States, ratified by each of the States, and declared by Article 6, Section 2, thereof, to be the supreme law of each of the States. It cannot be amended or modified, or varied by any State. They adopted the Constitution as a whole, Article 5 of which provides that amendments to the Constitution, to be effective, must be "ratified by the Legislators of threefourths of the several States, or by Conventions in threefourths thereof." The Constitution is not, therefore, to be like the law of the Medes and the Persians. It changes with the changing moods of three-fourths of the States.

${ }^{2} M c C$ ullough v. Maryland, 4 Wheaton, 316, 403. 
The States created the government of the United States as their agent for the purposes which they stated expressly or by necessary implication, and for none others. Additional powers may be added by amendment. The Legislative branch, consisting of a Senate and a House of Representatives, has certain specified powers; the Executive branch, whereof the President is the head, has prescribed duties; the Judicial branch, of which the Supreme Court is the head, has certain jurisdiction. Any group of foreign States wishing to follow the example of the American states can. They do not need to confide so many powers upon the government of their creating unless they want to do so. But there are two things of fundamental importance which they should do, if they want their union to outlive its makers: they should eliminate the question of large and small States, as the wise men of the Federal Convention did, by providing that one of the chambers, which we call the Senate, should represent the States equally, and that a second chamber, which we call the House of Representatives, should represent the States according to population. In this way, each branch would have a veto upon the abuse of power by the other, and by means of a conference committee between the two houses, there would be passed under the pressure of public opinion such legislation as was needed.

The second requisite is that to the extent of its granted powers, the government of the Union should act upon each member of the State. States cannot act themselves, they must act by agents. An agent attempting to do an act contrary to the fundamental law can be restrained. As the act, therefore, is not committed by the State, but by an individual, the State is not involved, merely the person claiming authority which he does not possess, whether that be under the statute of a State in conflict with the act of Union, or due to a false interpretation of the act of Union. This simple principle, new in political science, when it was devised by the wise men of the Federal Convention, has made it unnecessary to coerce sovereign 
States, which the wisest of that assembly, Messrs. Mason and Madison, Hamilton and Ellsworth, knew was impossible, and said so both in and out of Convention.

To interpret the Act of Union and, in so doing, to assure to the government of the Union its full rights, to protect the States of the Union in the exercise of their rights, and to define the duties of each, in their appropriate spheres, we have the Supreme Court of the United States.

The nations have made a beginning. We are familiar with conferences at The Hague. They can meet at stated intervals, submitting their acts to each nation for ratification, and binding only those that so ratify. This would prove itself to be in the course of time no mean legislature. A committee appointed by the nations might act in the interval of the conference, and exercise such powers with which the nations in conference should vest it. A Court of the Nations could be created, indeed, it apparently has been created by act of the Assembly of the League of Nations, on the I $3^{\text {th }}$ day of December, 1920.

If Europe should wish to follow Dr. Franklin's advice, the way is still open. Should all the nations wish to follow in the footsteps of the conferences which have met at The Hague, and, without creating a close union, organize the world upon the basis of justice and the rules of law, this can also be done.

In either event, the experience of the United States will be helpful. For this country of ours was founded, as James Russell Lowell has so beautifully said, "By men with empires in their brains."

JAMES BROWN SCOTT. 



\section{Economic Factors in International Relations}





\section{ECONOMIC FACTORS IN INTERNATIONAL}

\section{RELATIONS}

I.

\section{ECONOMICS AND POLITICS}

Of our domestic issues perhaps eight out of ten are distinctly economic in character. Likewise, in our international relations the proportion is probably as great. Economic forces directly affect the course of trade between different peoples, the intercourse of their governments and the activities of their consular and diplomatic representatives. The very fact that a country becomes commercially great in itself creates wider and more important relations with the rest of the world, in the management of which the best trained economic minds are constantly needed.

It was economic development, a growth of wealth and commerce, that brought Venice to leadership in the Mediterranean. "He hath an argosy bound to Tripolis," said Shylock, "another to the Indies; I understand, moreover, upon the Rialto he hath a third at Mexico, a fourth for England." This international character of her trade and the diversity of the world's coins which poured into her markets directly forced the solution of a common means of payment and the first issue of notes by the Bank of Venice. It was the hunt for wealth and the precious metals which sent Columbus adventuring to the New World. The consequent stream of silver from America and its effect on Europe during the reign of Charles V. set in train the theory of a favorable or unfavorable balance of trade (depending on whether or not a country maintained an excess of imports in specie), the error of which has not disappeared even to this day. Then, again, international contacts were made by the Hanseatic League, with its seat 
at Lubeck; and later the wide-flung fleets of the Dutch brought new international relations, especially with England. In recent years, the most prominent example of all has been the extension of British economic relations with every country in the world. So that, at least as one of the reasons, diplomatic missions to the Court of St. James become of the most conspicuous importance-that is, when we are not considering mere social relations. Why is it that contracts and bills of exchange all over the world, in every port of the distant seas, have been drawn in terms of pounds sterling? The most casual observation thus shows us how economic forces function in endless variety between nations.

Indeed, it is difficult to see how a mere adroit politician and bargainer, even though trained in the formal diplomatic conventions, can properly handle the issues constantly arising out of the increasingly economic character of international forces. Either he must be economically competent, or he must rely on the so-called "expert" on subjects in which he may easily be deceived. With the yearly expansion of industry and wealth, of rapid means of communication and transport, these economic matters push to the fore with such dominating persistence that they will not be denied.

We have a striking illustration in point at the present moment in the difficulty of settling on the amount of the reparation to be paid by Germany to the Allies. In the beginning of the discussions at Paris as to what could be exacted from the defeated enemy, a grave error was committed by attempting to fix the amount by reference to Germany's wealth and income. As a consequence very exaggerated sums became possible to the imagination of the victors. French financial policy was seriously affected by false expectations; and Lloyd George went to his electorate in the memorable election of December, 1918, promising them indemnity for the largest part of British war expenditures. The report by the economic section, however, showed conclusively that the sum must bear direct 
relation not to statistics of wealth but only to Germany's producing power. It is obvious that a proportional part of German wealth in the form of mines, furnaces, mills or farms could not be handed over as reparation. There could be taken only a part of the output from these and other productive sources. Nor could she pay in this output of goods unless she could get the cotton, copper, rubber, and like materials to be used in her productive processes. Eggs cannot be laid if hens are cut off from food. On the settlement of this matter of the German reparation and the removal of the uncertainty attached to it hangs much of the economic readjustment of Europe; and the solution would directly affect the foreign exchanges and our own industrial recovery. The insistency of an economic understanding of the most pressing and practical international question today is only too painfully evident. $^{1}$

II.

\section{MOVEMENTS OF POPULATION}

When we seek the fundamental economic forces underlying our necessary international relations we come first to the movements of population. These are primary causes of international reaction. Impelled by the pressure of numbers on subsistence there were the early incursions of the Goths and Vandals over eastern and southern Europe and the surge of the northern Teutons over Germany, France and Spain. But in modern days, questions of immigration and emigration touch very sensitive international nerves. These are so numerous and so obvious that it is not possible to be exhaustive in this paper. At the best we can only hope to be suggestive in a way to stir reflection and open the path to individual study.

One interesting form of international relations arising

${ }^{1}$ Cf. J. M. Keynes, The Economic Consequences of the Peace (19), and Bernard Baruch. There is a review of Baruch's book by Keynes in the New York Evening Post, Dec. 4, 1920. 
out of immigration to the United States from Italy and its reaction on the foreign exchanges has appeared since the European War. The Italians who have come to the United States and to South America have been industrious and thrifty. A part of their savings have in the past been sent back to Italy. From the United States some $\$ 80,000,000$ and from Argentina some $\$ 50,000,000$ have been annually returned home. During the war Italy placed an external loan with the United States and Great Britain of about $\$ 2,500,000,000$, the interest on which, at 5 per cent., would amount approximately to the sum which she could expect as a credit in the international account from her emigrants. That is, Italy needed to import coal and raw materials to keep her industries going and her workmen employed. It was vitally important for a country with a surplus of labor to be able to send emigrants to other countries and to receive back their savings, especially in this critical time of readjustment. But at the present time, either as a protection against Bolshevistic immigrants, or as a means of reducing the competition for employment, attempts have been made to stop immigration for a period. Such measures, however, are not simple in their effect and are certain to complicate our international relations.

One other case may be mentioned wherein the question of immigration has created at this very time a diffcult international situation. Inter-racial problems have been introduced by the coming of the Japanese, Chinese and Hindo immigrants to the Pacific Coast. In the passage by California of legislation discriminating against Asiatic immigrants in regard to property and civil rights, internal economic issues openly clashed with our international relations. ${ }^{1}$ The agitation against the Japanese laborers originated with the labor unions. Their purpose was obviously to restrict the numbers of those who might

${ }^{1}$ Cf. H. A. Millis, The Japanese Problem in the United States (1915); J. F. Steiner, The Japanese Invasion (1917). 
compete with American laborers. It was a contest between economic standards of living. As contrasted with Americans the Japanese were superior in thrift and often in industry and patient agricultural skill. Willing to subsist on less and to work harder, they excited the animosity of those who believed that when beaten in open competition they could protect their economic position by legislation. The fundamental error in this attitude, quite too common in the policies of the leaders of "organized labor," is the supposition that employment is increased by restriction of production. It is folly to hold that there is only a limited amount of work and that it can be distributed among a restricted monopoly of laborers in the form of higher wages, for each. On the contrary, greater efficiency and lowered cost of production have been proved by long economic experience to be the basis and reason for higher wages. If the Japanese increase productive efficiency and turn out more wealth at lowered costs, they enlarge the volume of goods, thereby increasing the margin from which capital can be saved, increasing also the trade and commerce of the country, its transportation and shipping, and inevitably extending the demand for labor of all kinds. For temporary freedom from competition (which is, after all, not real) the labor organizations are willing to lose a future gain arising from enlarged general prosperity and greater employment.

The statesman, however, in acting upon public questions, is obliged to consider not only the economic, but the ethical and political elements of the case. Unfortunately, while the appeal to economics gives an unequivocal answer, racial prejudice and selfish politics have entered into the local problem so as to confuse the issue. Moreover, under our form of government, in making treaties with foreign countries, the United States cannot control the action of a State in certain reserved powers. Hence an individual State on the sea coast may greatly interfere with a national foreign policy. From the Japanese point of view, their direct opposition is to the discrimination 
as to civic and property rights against them which does not hold against other people. We have allowed Germans to hold property and obtain civic rights in our land. Why not the Japanese?

\section{III.}

\section{FOREIGN TRADE AND SHIPPING}

As we enter further into our subject we find that the immediate and inevitable economic contact of one country with another is through its foreign trade and its shipping.

From the very beginnings of our national existence equality of treatment between American and foreign ships became a burning issue. To meet the British Navigation Acts, we discriminated in 1789 in favor of our ships by tonnage duties, and in the same year by customs duties. The regulations against foreign vessels in our coastwise trade have been so stringent that since I8I7 Americans have maintained a strict monopoly in that trade. In the foreign, as contrasted with our coastwise, shipping, we soon found we could not apply discriminating treatment in our favor without meeting with drastic retaliation from foreign countries. When our ships entered foreign ports they were likewise met by discriminating duties against us. The crass assumption that we could sell without buying was finally given up about I830. It reappears now only in the occasional offer of a bill by some callow statesman from Buncombe County.

During the Napoleonic wars the Order in Council of I793, the Blockade of I806, the Berlin Decree, another British Order in Council, and the Milan Decree, inflicted heavy losses on neutral American shipping. Thereupon, Jefferson, with an exaggerated conceit as to the importance of our commerce to European combatants, created the Embargo Act of 1807, which ruined our commerce but did not prevent war. Then came the Non-Intercourse Act (1809), followed later by the War of I812. Nor did we get the principle that "free ships make free goods" inserted in The Treaty of Ghent. We tried the experi- 
ment of extreme nationalism, but without much of the gain that might have arisen from a more flexible system of economic co-operation with the rest of the world. ${ }^{1}$

On matters of shipping, the American mind has remained largely provincial and unprogressive. The whole story is too long to be taken up here; but it may be permitted to present one modern instance of the way in which our international relations are at this very moment being shaken by questions involving our shipping policy. A vigorous chauvinism on our part has led to an attitude on Panama Canal tolls for American ships that is very much questioned by foreign countries. Just as the Suez Canal, so does the Panama Canal touch the shipping and commerce of all nations. If we wish equal treatment for our ships passing through the Suez Canal, other commercial countries would likewise expect equal treatment for their ships passing through the Panama Canal. In the Clayton-Bulwer Treaty (April 19, I850) between the United States and Great Britain, it was agreed as a matter of course that in any canal between the Atlantic and Pacific Oceans "any rights or advantages in regard to commerce or navigation" shall be offered "on the same terms to the citizens or subjects of the other" (Art. 1.) ; and that "its neutrality shall be guaranteed so that the said Canal may forever be open and free" (Art. V). This convention was superseded by the Hay-Pauncefote Treaty of November I8, 1901. Following the rules of the Suez Canal (as of October 28, I888), the United States agreed that (Art. III., I ) :

"The canal shall be free and open to the vessels of commerce and of war of all nations observing these rules, on terms of entire equality, so that there shall be no discrimination against any such nation, or its citizens or subjects, in respect of the conditions or charges of traffic, or otherwise.

On this solemn international covenant, the United States

${ }^{2}$ Coman, Industrial History of the United States (1910), Ch. V., VI. 
was given a free hand in the construction, "as well as the exclusive right of providing for the regulation and management of the canal" Art. II).

It will be recalled that by our navigation laws only American ships were allowed in our coastwise, as distinguished from our foreign, trade. Then, in preparation for the opening of the canal August I5, I914), Congress passed the Panama Canal Act, August 24, I912, which provided (Sec. 5) that, "No tolls shall be levied upon vessels engaged in the coastwise trade of the United States", Such a provision, of course, raised the question whether, by excepting these American ships from tolls, we had violated our solemn agreement of the Hay-Pauncefote Treaty of I9or. Could it be said that the termini of the Panama Canal were coastwise ports of the United States? Evidently not, for foreign ships were admitted. On what grounds could we justify the exemption? Whatever the basis, this exemption was repealed by Congress in the Act of June I5, I9I4. Senator Elihu Root's speech (63d Cong.) showing that we were morally bound to repeal this exemption will remain one of the remarkable pronouncements in a very exciting debate. The repeal went through by the influence of President Wilson (in spite of the Baltimore platform) in favor of freer trade. At this period, also (August 18, I9I4), an Act was passed to encourage the regisration of foreign-built vessels under the American flag by suspending the age of vessels (five years) applying for registry, and other restrictions as to nationality of officers, survey, inspection and measurement.

We know that President Harding, while Presidentelect, visited the Panama Canal with the purpose (if correctly reported) of recommending the restoration of the exemption, which was mentioned in the Republican platform. The position of Mr. Harding is evidently that of the protectionists who have long worked to eliminate foreign competition both in ship building and in ship operation. The presence of this matter in the platform was 
not to satisfy any hostility to Great Britain, but to give cheaper rates to the lumber industry and a few other interests on the Pacific Coast. Very few members of the committee on resolutions at the Republican convention knew this plank was in the platform. In order to give an advantage to certain Pacific Coast interests, at the expense of others in the Mississippi Valley, on the general theory of protection, a domestic economic question has been allowed to create an embarrassing policy inconsistent with our treaty relations with Great Britain.

Now that the end of the war-stimulation of ship building is past, and a surplus of ships is lying idle in our ports as well as in many ports throughout the world, we are likely to hear more of the protectionist measures to aid shipping by subsidies and bounties, ${ }^{1}$ which have hitherto been repudiated by American voters.

\section{IV}

ECONOMIC POSTULATES OF FOREIGN TRADE

The very existence of foreign trade between nations arises from fundamental economic principles. One of the earliest developments in industry was the recognition of the advantages flowing from division of labor, which, of course, are familiar to you all. It was an expression of the need for men to overcome the innate centrifugal tendencies of individualism in favor of co-operation in work, which would result in greater satisfactions for less effort. That one man, or one group, should specialize and gain skill in producing one article or even a certain part of one article, has enormously multiplied the productive power of industry and added uncounted comforts even to the poorest ranks of society. International trade is but an application of the principle of division of labor to the wider industrial operations of different countries with their

${ }^{2}$ W. T. Dunmore, Ship Subsidies (1907). 
various characteristics of soil, climate and racial development.

There will be no such trade unless there is a mutual gain. Hence international trade arises out of the fact that one country possesses a relative advantage in the production of one commodity (A) while another country has a relative advantage in a different commodity (B). By exporting $A$ to pay for an import of $B$ the first country gains by not having to produce $B$ in which it has the relative disadvantage; and the other country gains conversely by putting its productive effort into $\mathrm{B}$, in which it has a relative advantage, and obtaining the imported commodity $A$ at the cost of producing $B$. This operation, based on reciprocal advantages in some articles relatively to others at home, is what is known as the working of the Doctrine of Comparative Costs. It is the cause of the existence of all international trade. Under it, the vast exchanges of goods between nations goes on, and the international relations arising from this commerce have become numerous and intricate; but yet they must conform-whether we realize it or not in our daily transactions-to the simple economic principle just described. Any domestic policy adopted in ignorance of its working is sure to be visited with inevitable failure.

As usually happens in the experience of both men and nations the definite and unequivocal results of purely economic forces are not allowed to take place unhindered by the interference of selfish, private or nationalistic interests. The reciprocal gains from international trade are fully reaped only when no obstacles are introduced to check the free movement of goods between countries. But tariffs on the importation of foreign goods, export duties on home products, restrictions on the movements of the precious metals used in settling international balancesto say nothing of resolutions and actual warfare-all work to reduce the mutual gains naturally issuing from foreign trade. There comes a conflict between economic forces and those of a nationalistic, political, or racial char- 
acter. In the long run economic forces assert themselves, but for the time being there is usually a perturbation due to the conflict of these forces. As a consequence international relations are in a constant state of unrest, requiring of those in charge of foreign affairs a penetrating economic insight.

For instance, the moment the United States Congress takes up the question of imposing protective tariffs on the products of Argentine seeking a market here, a serious conflict of interests arises. If one of our industries wishes to shut out competition from an exporter in Argentine, then an Argentinian firm in another industry has a basis for asking his country to keep out an American commodity by import duties. There can be no economic or international gain by such retaliation. It cuts directly at the operation of the principle of comparative costs. If we do not admit the goods of other countries in which they have an advantage they cannot pay for our exports to them. No country can expect to sell abroad any and all commodities, and then, if pinched by high costs in certain goods in which we are at a relative disadvantage, ask for protective duties or subsidies on them. If costs are relatively high, that alone proves we are employing our labor and capital at a disadvantage, and to keep on is kicking against the pricks. Therefore, that industry, which asks for artificial support in protective duties under a false chauvinism is working against our national welfare as a whole just as much as he who burns up a warehouse. What he is paid for, by insurance or by taxes, the country as a whole loses.

At this very time, also, politicians, representing the unthinking demands of our farmers, propose to lay duties on imported farm products. Here comes in the working of comparative costs. We have a relative advantage in wheat and corn because of our extensive cultivation and the liberal use of agricultural machinery as compared with Europe; but hemp and flax, for example, require much labor in intensive cultivation and make little use of ma- 
chinery. Our farm labor yields more wheat and corn for its efforts than it does in growing flax and hemp. Hence we import hemp and flax for fine goods, even under protective duties. ${ }^{1}$ Protective duties on wheat and corn would be futile, because we export them. Such duties would not raise the prices to our farmers, because they are fixed in the markets of the world, and yet it is seriously proposed by heavy duties to prevent Canadian wheat entering our country. The proposal is absurd. Two rivers flowing side by side into the gulf affect the level of the sea just the same as they would if one river were diverted into the channel of the other and poured out their joint volume through one mouth. Canadian wheat will enter the world's market by its own channels and affect the world price just as much as if it travelled part of the way on our railways and ships.

Any producer of goods can go on only if he finds a buyer. Under division of labor one man's product is his means of buying the goods of another. In our modern industrial organization no industry can live in and for itself. It can exist only by a system of exchange of goods one for the other. That is, the interdependence of industries one upon another is the logical and inevitable consequence of that separation of occupations with its intensive specialization which is the characteristic difference of modern from primitive industry. Successful and increased production of desired goods by one means an increased effective demand for the goods of all others. The prosperity of the one stimulates prosperity of the others in the chain of exchange; the disaster of the one brings loss to the others.

This interdependence of our domestic industries one upon the other holds quite as truly of one commercial nation upon another. America cannot sell, if Europe and foreign lands cannot buy. Never was that simple truth

\footnotetext{
${ }^{1}$ Cf. F. W. Taussig, Tariff History of the United States, 4th Ed., pp. 364-409.
} 
more evident than it is today when we look abroad over the turbulent countries lately emerging from the World War. Our products need foreign markets. In no better way can we illustrate the active influence of economic factors in our international relations than by an examination and explanation of the present commercial and industrial conditions affecting our trade and credit relations with foreign countries. We shall not have to proceed far before we come to see that the complicated political and international questions now up for settlement by the League of Nations are entirely dominated by fundamental economic considerations.

\section{V.}

\section{FOREIGN EXCHANGE}

In the settlement of transactions between nations a peculiar language has sprung up descriptive of international payments naturally different from that in use in our domestic operations; but the functions to which they apply are essentially the same. Instead of dollars and checks at home, we hear in international usage of pounds, francs, or crowns and bills of exchange. In our domestic trade the values of goods are offset against each other by the clearing of checks drawn on deposit accounts; but in international trade the instrument used is a bill of exchange. It keeps the international account open, while debits and credits on all kinds of items are allowed to be offset, saving the transmission of gold on industrial transactions, and allowing its shipment only for the settlement of balances. The economic relations between different countries at any given time can be read clearly in the state of the foreign exchanges and its rates. At the present day the working of the market for bills of exchange between the United States and Europe is a matter of vital concern. If A sells coal to France or Italy, in what is he to be paid? Gold will not be sent him, for various reasons I need not go into. As compared with our dollar, francs 
and lire are now at a very heavy discount. A has a claim, say, for $\$ 10,000$, the price of his coal. By a bill of exchange drawn on the foreign buyer he can sell that claim to a New York bank dealing in foreign exchange. That number of dollars would today be worth 140,000 to I 70,000 francs (instead of 5I,800 at the pre-war par). To pay three times as many francs as before the war for the same coal, solely because of the higher rate of exchange between francs and dollars, makes coal very high to the French. The same process goes on for all imports into France or into other countries whose exchange is at a discount. Such a situation produces great distress.

If, however, a Frenchman could export to New York silk goods worth here $\$ 10,000$, he could by a bill of exchange drawn on the American buyer sell his claim on New York to the French buyer of coal and the import would be paid for by the export. The value of one shipment would offset the other. Or, as generally explained, if all exports and imports just balance, exchange would (other things being equal) remain at par. But the practical operations are not so simple as that. Besides the movement of goods, bills are drawn on other items in the international account, such as the sale of securities, travellers' expenses, freight charges, or settlement of debts; and when all these credits and debits are offset, even the balance may be carried along without a shipment of gold.

Now, if all these items were today in equilibrium, would the rate of exchange between France and the United States settle about par? I think not. There are two distinct elements now affecting the rate of exchange. If French imports greatly exceed her exports she can normally settle that balance against her only $(a)$ by sending goods, or $(b)$ sending gold, or $(c)$ obtaining credit by the sale of bonds to the creditor country. France and all the belligerents need the food and raw materials we export in order to produce the goods which they can send out in payment. As everyone knows, exceptional efforts are being made through the formation of foreign finance 
companies to give Europe long-term credits when buying materials and food from us. Only in that way can she increase her exports of goods. There is already a very marked gain in English, Belgian and French exports. But even when these exports of goods begin to equal the imports of goods, we will not have seen the end of the great discounts of foreign exchange. On this very point there is need of an important concentration of attention both here and in Europe.

The reason why the heavy discount on foreign exchange is likely to remain, even after production of exports has grown, resides in the second element affecting the excharge. (2) That is the depreciation of the current money in Europe due to inconvertibility into gold. In France (to revert to our illustration) redemption of Bank of France notes was taken away in August, I9I4. In addition, mainly through making advances to the State, the issue of these notes was increased from 6 to 37 billion francs (or, at nominal par, from $\$ 1,2$ 10 to $\$ 7,536$ millions) from June 30, I9I4, to January I 5, I920. Until these notes can be so reduced in quantity, through repayments by the State to the Bank, that the gold reserve of 5,579 million francs (or \$I, I 6 millions) is sufficient to maintain redemption of the notes in gold, these inconvertible notes will circulate at a discount. Such redemption is likely to be delayed from ro to 20 years. Meanwhile, bills payable in francs-whether there is an equilibrium between French exports and imports or not-will be worth no more than the value of the inconvertible paper francs in which they are payable. Consequently, the American who exports goods worth $\$ 10,000$ to France will expect to receive for his bill as many more than the par of 5I,800 francs as will give him an equivalent for his $\$ \mathrm{r}, 000$ in gold. If a Frenchman can buy a dollar with 8 francs (instead of 14 to $I 7$, as now), even after such a recovery, he will have to use 80,000 francs to buy a bill on New York for $\$ 10,000$. That, of course, means an equivalent discount on French bills of exchange. And 
this discount in the exchanges will exist for reasons wholly independent of the equilibrium between exports and imports; for these reasons have to do with the possibility of redemption of the franc in gold. The bill of exchange - the medium of exchange in international trade-will remain at a discount unless it is redeemable in gold, just as any domestic medium of exchange (like our greenbacks) would, if not convertible into gold. In short, while it is of the first importance to aid Europe by credits to rehabilitate her industries and increase her exports, with which she can pay for her imports, the difficulties due to the depreciation of the franc as compared with our dollar will still remain. Very little recognition seems now to be given to this second element affecting the rate of foreign exchange. It will continue to increase the cost of her imports to Europe and afford a premium on our exports. . It would be much as if a gold standard country (like the United States) were trading with a country having a fluctuating silver standard.

\section{VI.}

FINANCIAL AND INDUSTRIAL OBSTACLES TO INTERNATIONAL PEACE

As a final illustration of the influence of economic factors on our international relations we find it in the overwhelming difficulties now checking the industrial recovery in Europe and the settlement of the terms of peace. Those of us here, in the comparative prosperity and security of the United States, have little conception of the prodigious tasks-financial and industrial-which confront the peoples of the belligerent nations. Great Britain and Belgium have made the most progress; but France and especially Italy, with central and southeastern Europe, are face to face with tasks to daunt the ablest statesmen. To top it all, they are treading on the red-hot gridiron of radical revolutionary excitations. We are fast reaching the point when it is beginning to be generally understood 
that the diplomatic and political policies must be mainly subordinated to, and interpreted by, economic considerations. At the bottom of the deplorable European uncertainty and confusion lies the question of the economic rehabilitation of industry. What methods can be adopted to bring it about?

Behind the courteous language of diplomacy we must understand that there is no sentiment in the negotiations for peace and the economic readjustment. We are wanted in Europe because it is hoped we can be induced to bear the burden of financing its people during this critical period. And although we spent in the war about \$34,000,$\infty 00,000$, without hope of any recompense but safety from the aggressions of Germany, Europe still looks to our comparative superiority in resources for rehabilitation. It is not because we are liked, but because we can grant credits, that we are sought for. It is practically an economic matter. But, besides a moral obligation to succor distress among neighbors it is wise for us to see the facts just as they are. Whatever we do we need not expect gratitude.

Stand with me, if you please, in the town of Lens, in the coal district of northern France, a short time after the armistice. Where once there stood I I, 000 houses there are only roads cleared through a desert of battered bricks and ruins; not one house is standing; not one coal shaft can be worked. In the cold winter rain a one-horse load of household goods pitifully carries an old woman on top, exposed to the storm, and a boy leads the gaunt little horse. What is the process of reconstruction? Freedom from war, and the opportunity to get to work again. The old woman and the boy clear up a corner against a wall, pile up the loose bricks in three walls, cover the top with stray pieces of corrugated iron, for a stable. They find shelter in a cellar or a dug-out, and make a fire. They are pioneers in an old land. The next evening is seen the age-old miracle of hope triumphant over despair when the horse and plough rise over the hill against a crim- 
son sunset, turning up the soil of the battle ground. This I have seen. It is typical of reconstruction whether on the farm or in the factory. There must be peace, freedom from upheaval, and steady, persistent work. Getting on with the barest necessaries of life, soon you begin to see new houses, shell-torn roofs repaired, chimneys smoking. Under such enforced saving, a few comforts and nonessentials soon appear here and there:

The labor force is less than of old. But after Germany was forced to disgorge its stolen machinery, the repaired factories were ready to work. Then, who will provide the raw cotton, the wool, the jute, the copper, the rubber, and the coal to set the man at work and produce the goods by which imports can be purchased? If Europe had been at once given a start by credits to buy materials and restore transportation she ought now to be humming with industry. Food is yet needed until the land is again producing with fertilizers as of old. This is the reason why our bread stuffs, our materials and our coal are still pouring into Europe in a large volume. But how can they pay us? Suppose they are granted credit. At the maturity of a credit, how can they pay? Only in goods. Therefore, the solution is one of productive power to be built up by labor and capital in the varied forms of material, equipment, machinery and transportation.

How goes the struggle for this rehabilitation? Have peace and order, after war, been given to Europe so that she can give all her energy to developing her productive power? Here is the crux of the whole matter. What is going wrong now after more than two years since the armistice? Let us face the actual situation, much affected by wrong-headed blundering at the expense of suffering to millions of innocent people. (I) In the first place, a vague, new experiment in a League of Nations ought to have been separated from the immediate establishment of peace. The organization to enforce the terms of peace and to establish law and order should have been separately worked out, taking the necessary deliberation with- 
out delaying peace. (2) That, however, is a matter of the past. We must take the situation as its exists. Instead of an obvious need for order in which to restore the ravages of war and to stimulate production, we find the military and naval expenditure of Europe still enormously and criminally high, still wasting the productive resources of an exhausted world. (3) An abnormal expenditure, without regard to the actual revenues, without balancing the budget either by increasing taxation or by cutting down national expenses, is sadly common. It seems like the doings of bedlam. (4) Worst of all, the currencies and credit of Europe have been so extended on unsound assets or on a mere fiat issue that trade in goods between nations is inevitably crippled. The German mark, for instance, is almost as worthless as our old Continental currency. The Reichsbank holds only about $\mathrm{r}, \mathrm{IOO}$ millions of marks in gold $(\$ 275$ millions at nominal par) for some 64,000 millions of notes $(\$ 16,000$ millions at nominal par). This is hopeless bankruptcy for a bank of issue. (5) Finally, the actual amount of the indemnity to be paid by Germany has long remained unsettled to the confusion of French and other budgets. Either Germany must be allowed to import materials and develop her production of goods for export, or France must be content with a bankrupt Germany unable to pay any indemnity.

In conclusion, what methods of relief can be adopted? We may dismiss those that assume the cancellation of war debts due the United States, as well as those proposed at the Brussels Conference for an international bank intended to raise credits on possible resources of crippled countries, since internal conditions make these assets unbankable; or, an international syndicate for the investigation, organization and control of transactions to obtain raw materials. The only other proposal at the Brussels Conference, and which appears in the same general form in that of Sir Robert Horne (Jan., I92I), is that the Government of an importing country should support a bond to be given by the importer in payment (or as security) 
for foreign goods. This is one of the various attempts to get governmental credit when the credit of the importing borrower cannot stand on its own legs. Much the same idea appears also in the (Brussels-Geneva) scheme of the Council of the League of Nations (Dec., 1920). The essential idea in all of these plans is a demand for governmental aid which also turns up in our revival of the War Finance Corporation, at the urgency of our farmers who wish to sell bread-stuffs abroad.

All of these proposals are only palliatives. They extend promises to pay. It is true, like a push behind a damaged automobile, they may start the wheels going; but, if the damage is internal, the machine will soon stop again. The remedy must be applied to the restoration of the propelling force within. In economic terms, that means for permanent effect the building up of productive power, the first condition must be the establishment of order and freedom of opportunity for labor. Not only does this imply the cessation of war and the heavy expenditure associated therewith, but, above all, the removal of revolutionary socialism which is throttling the possibilities of steady production. The activities of fanatical agitators to overturn the industrial system create the very reason why capital will be alienated from co-operating with labor in production and why credit will not be granted to disturbed industries. When Europe quiets down and turns to normal efforts to produce, the credit system will quickly respond to her needs. Of course, materials and coal are now essential, and credit is needed to procure them. If this were all of the situation, there would be little difficulty in obtaining from private sources the desired credit without an appeal to governmental aid. Au fond, the Government can supply credit only by resort to private sources. If the application is a doubtful case, unsatisfactory to private lenders, then it is likely that we shall have an appeal for governmental help. The true remedy for unsettled Europe is to drop politics, international rivalries and revolutionary plots, and go hard to work. With the 
recovery of economic normality, international difficulties would rapidly dwindle; such things as matters of exchange would soon take care of themselves, especially if measures are undertaken to reduce and redeem the note issues.

Men appointed for political reasons should have no place in our diplomatic service in these days when economic questions have such paramount importance. Not only should long training and the chance of a permanent career be the well-known conditions to entrance into this service, but everyone who represents our country as a consul or a minister or an ambassador should be trained how to think on economic questions. Economic conditions in all classes of people, everywhere, in all countries, directly affect their state of mind and color all our international relations.

$$
\text { J. LAWRENCE LAUGHLIN. }
$$



Specific Agencies for the Proper Conduct of International Relations 

SPECIFIC AGENCIES FOR THE PROPER CONDUCT OF INTERNATIONAL RELATIONS

I.

AMICABLE METHODS

The subject which I have undertaken to treat in the present course on the history and nature of international relations I interpret as embracing all the various agencies or methods of international intercourse. Thus interpreted, it embraces both amicable methods, including negotiation, good offices, meditation, and arbitration; and non-amicable methods, including the withdrawal of diplomatic relations, retorsion and retaliation, the display or use of force, pacific blockade, reprisals, and war.

Practitioners of private law, who are accustomed to think of law only as it is administered by municipal or domestic courts, are often inclined to deny legal classification to the rules and methods by which international relations are conducted. Perhaps we may say that, in proportion as one has occasion to deal with international affairs, he ceases to be controlled or misled by such a conception. In the sense that force cannot always be immediately and effectively applied in the international sphere to the accomplishment of a particular object, and that definite and common agencies are not provided in advance for its application, the administration of international law differs from the administration of municipal law. But it by no means follows that law and agencies for the administration of law do not exist in the international sphere. In reality, organization exists in the domain of international relations and is made effective through its own appropriate agencies and methods. 


\section{NEGOTIATION}

The ordinary method of conducting international relations is that of negotiation, which we may call the normal legal mode of international intercourse. This process is carried on by the duly appointed official representatives of governments. In ordinary circumstances these representatives are the regular, permanent diplomatic representatives, but when the exigencies of the case seem to require it, special or additional representatives, official or unofficial, are employed.

By the rules of the Congress of Vienna, as amended by the Congress of Aix-la-Chapelle, diplomatic agents are divided into four classes :

( I) Ambassadors, legates and nuncios;

(2) Envoys, and ministers plenipotentiary;

(3) Ministers resident;

(4) Chargés d'affaires.

Legates and nuncios are the representatives of His Holiness, the Pope, while ambassadors constitute the highest rank among the representatives of civil and political powers. The most highly esteemed privilege of the ambassador is that, as the peculiarly personal representative of the head of his own State, he is supposed on all occasions to have a right of access to the head of the State to whom he is accredited, together with the happy and comfortable privilege, so conducive to tranquil slumber in the later morning hours, of compelling his diplomatic colleagues of inferior rank to wait for access to the secretary of state or minister of foreign affairs so long as there is an ambassador within sight or sound.

In one respect the ambassador shares titular but illusive honors with the envoy or minister plenipotentiary. The ambassador's proper full title is "Ambassador Extraordinary and Plenipotentiary," while the envoy's proper full title is "Envoy Extraordinary and Minister 
Plenipotentiary." In reality, neither the one nor the other is either extraordinary or plenipotentiary. These titles have come down from the days when special rather than permanent missions were the rule, and when ambassadors and envoys were actually invested with full powers, in order to meet the extraordinary occasions which called for their appointment. Today the usual powers and credentials of ambassadors and envoys suffice only for ordinary occasions. No government would dream of concluding a treaty with an ambassador or envoy unless he had a special full-power. The minister resident, like the ambassador and the envoy, is entitled to an audience of the head of the State on the presentation of his credentials; but the envoy and the minister resident can claim no such right in the subsequent conduct of their business.

Chargés d'affaires are divided into two classes: Heads of missions, and (2) persons temporarily in charge in the absence of the head of the mission. The first class merely represents the lowest rank of permanent diplomatic representation. Neither class is entitled to access to the head of the State, but is accredited or presented to the secretary of state or minister of foreign affairs.

Immunity from ordinary legal process belongs alike to all persons possessing a diplomatic character. This immunity is sometimes called extraterritoriality and, when, interpreted in the sense of this highly metaphorical word, is often greatly exaggerated. It is sometimes said that diplomatic representatives are wholly exempt from legal obligation, and that their residences are foreign ground. Such conceptions are creatures of the imagination. They have no foundation in international law or practice. No man is above the law, in the sense of being exempt from the duty to obey it. The fact that a diplomatic officer is exempt from the service of ordinary legal process, rather than from the duty of obedience to the law, is readily demonstrated by the fact that if, after his commission of an act which the law criminally forbids, his government with- 
draws his immunity, he can be prosecuted for his offense subject to the exercise of what may be called preventive power, employed for the purpose of forestalling or staying the violation of laws and policing regulations made for the purpose of protecting life and property from destruction or injury. On the other hand, it is proper to repeat that persons having a diplomatic character are not subject to ordinary legal process for the enforcement of legal liabilities, either civil or criminal. This is a rule of international law, and the statutes of the United States provide for its enforcement by the courts, with appropriate penalties for its violation.

Diplomatic officers are not the only agents of the State of whom international law takes cognizance. Such agents comprise consuls, officers in command of the armed forces of the State, military or naval, and commissioners or other persons employed for special objects. But these non-diplomatic agents do not by virtue of their official character enjoy immunity from legal process unless it is specially provided for.

Before passing to other topics, it is proper to mention, in connection with the appointment, recall or dismissal of diplomatic agents the question of personal acceptability. In this relation we use the technical terms persona grata and persona non grata. Objections may be made to receiving a diplomatic officer, or to his remaining at his post, on the ground that he either is or has become personally unacceptable. The reason of this rule is that the chief object of diplomatic intercourse is the cultivation of good relations, and that the attainment of this object is of more importance than the personal fortunes of an individual. Except in extraordinary emergencies, which seemed to compel immediate action, it has been the rule, where a minister has become unacceptable, to seek for his recall. But, if his recall should be refused, his dismissal would not then furnish a legal ground of complaint. Sometimes controversies on the subject have arisen from the fact that it was alleged or believed that personal unac- 
ceptability was assigned as a cover for a different and unavowed reason.

\section{(b)}

\section{GOOD OFFICES}

The term good offices is used in the double sense ( $I$ ) of the unofficial representation or advocacy of interests of a particular government, and (2) the exercise of the function of an impartial adviser of the parties to a dispute.

The first sense is illustrated by the extension by a diplomatic officer with the consent of his own government and the assent of the government to which he is accredited, of unofficial protection to the citizens of a third country, as has for many years been done by diplomatic and consular representatives of the United States, by instruction of their government, in behalf of citizens of Switzerland. Yet another illustration is the unofficial representation, by a neutral diplomatist, of the interests of one belligerent at the capital of the other belligerent in time of war.

An illustration of the second sense is where a diplomatic officer acts as a friendly intermediary and counsellor of two or more governments with a view to compose a difference between them. Such action necessarily presupposes the assent of the parties to the dispute, and is indeed usually preceded by an invitation from them, collectively or individually. The employment of good offices, in this sense, is naturally a matter of much delicacy, and a diplomatic officer who is either called upon, or seems likely to be called upon, to act in such a capacity should be careful to avoid anything that might tend to affect his impartiality or to expose it to suspicion.

Good offices have been employed for many purposes and on many important occasions. Not only have they been used to adjust ordinary differences, but they have been employed to end war as well as to avert hostilities.

There is yet another sense, not falling within either of the two preceding categories, in which the term good offices is used, and that is in indicating the special char- 
acter of a government's interposition in behalf of one of its citizens in presenting his claim against a foreign government. It is common to speak of intervention in behalf of private claimants. This is in fact one of the recognized forms of intervention, and it implies that the government presents the claim as a matter of legal right, and its request for redress is considered as a "demand", although in ordinary circumstances the word is not used. Sometimes, however, governments are asked by their citizens to present claims which may not have a strictly legal foundation, or which may have arisen out of an alleged breach of contract. The government of the United States has constantly taken the position that persons who contract with foreign governments should take into account and assume the risk of such governments' disposition or ability to perform what they may promise to do. In such cases, where the claimant's request for aid has seemed to be specially meritorious, the United States has presented his claim to the foreign government by way of "good offices", thus indicating that the claim is presented in a friendly sense and in the hope that it may be properly considered and adjusted, but without a direct and specific request for its admission and settlement. Action in this sense has sometimes been described as "unofficial good offices", but the word "unofficial" has been used only accidentally, or perhaps for the purpose of emphasizing the unofficial character of the proceeding. The word unofficial is in such a relation superfluous, since the employment of good offices is essentially an unofficial act. There is no such thing as "official" good offices, and the term is never applied to the process.

\section{MEDIATION}

Sir James Mackintosh once defined a mediator as " $a$ common friend, who counsels both parties with a weight proportioned to their belief in his integrity and their re- 
spect for his power. "But," said Sir James, "he is not an arbitrator, to whose decision they submit their differences, and whose award is binding on them." In substance mediation is an exercise of good offices. The distinctive meaning which the term conveys is that the proceeding is attended with a certain formality, with special emphasis on the advisory or recommendatory phase. Not infrequently a mediation resembles an arbitration, except in the vital point that it does not result in a decision.

One of the most remarkable mediations of the United States is that which was begun in 1866 and concluded in 1872 for the purpose of bringing to a close the war between Spain on the one hand, and the allied republics of Peru, Chile, Bolivia, and Ecuador on the other. As early as December 20, I866, Mr. Seward instructed the diplomatic representatives of the United States near the belligerent governments to propose that a conference should be held at Washington. Spain was willing to accept the proposal on certain conditions. Bolivia and Ecuador were disposed to do whatever Chile and Peru might agree upon. Chile and Peru were willing to accept only on certain conditions, one of which was that Spain should acknowledge that the bombardment of Valparaiso was a violation of international law. This Spain refused to do, and Mr. Seward's first effort was thus unsuccessful; but, as the war itself eventually fell into a state of "technical continuance," he renewed his proposals on March 27, r868. Spain substantially accepted. Chile thought that the conclusion of a definitive peace would be impossible, but intimated a readiness to enter into a truce, which would offer to neutrals all the guarantees and securities which they could properly claim. Bolivia concurred in Chile's views; Peru and Ecuador were disposed to accept unreservedly. On October 22, I869, Mr. Fish, as Secretary of State, renewed the invitation for a conference. Such a conference was opened at the Department of State October 29, 1870, under the presidency of Mr. Fish. Owing to the question as to the 
bombardment of Valparaiso, it was found to be impossible to conclude a formal peace; but on April II, I87I, the delegates in the conference agreed upon and signed an armistice by which the de facto suspension of hostilities between the belligerents was "converted into a general armistice or truce," which was to "continue indefinitely" and could not be broken by any of the belligerents "save in three years after having expressly and explicitly notified the other," through the Government of the United States, "of its intention to renew hostilities"; and it was provided that, during the continuance of the armistice, all restrictions on neutral commerce which were incident to a state of war should cease.

This was a very remarkable document, especially in the fact that, as a pledge to refrain from hostilities, it was more effective than a treaty of peace. Treaties of peace, although they often contain pledges of perpetual amity, are usually interpreted in this regard as declarations of a present intention rather than of a continuing obligation, the parties preserving the "sovereign" right thereafter freely to choose between peace and war. The armistice of $187 \mathrm{I}$ precisely limited their freedom of action in that particular.

In recent days there has been an anxious agitation concerning the Island of Yap, which seems to have been destined to play the part of a storm center. Thirty-five years ago a dispute concerning it gave rise to one of the most interesting mediations of modern times. This dispute grew out of the action of a German Admiral who in I 884 raised the Imperial flag over the Island as a sign of occupation. In order that our thoughts may be clarified perhaps I should state that Yap is one of the Caroline Islands and that the Caroline Islands are in the Pacific Ocean. The act of the German Admiral provoked in Spain an outbreak of popular violence which was marked by attacks on the German Embassy and the German Consulate at Madrid. In order to avert hostilities, Prince Bismarck proposed the submission of the matter to the 
mediation of His Holiness the Pope. This proposal the Spanish Government accepted and on October 22, 188.5, His Holiness as mediator presented to the two governments certain propositions by which the sovereignty of Spain over the Caroline and Pelew Islands was confirmed, but by which Germany acquired special commercial rights, together with the right to establish a naval station and a coal depot in the islands. In conformity with the recommendation of His Holiness, his propositions were embodied by Germany and Spain in a protocol which was signed by their Ambassadors at Rome on December I7, I885.

In the discussion of good offices we have seen that considerations of propriety and of delicacy have tended to embarrass and prevent the employment of the process. The Convention for the Pacific Settlement of International Disputes concluded at The Hague on July 29, I899, undertook to remove this difficulty by stipulating that in case of serious disagreement or conflict, before an appeal to arnı, the signatory powers should as far as possible have recourse to the good offices or mediation of one or more friendly powers; that an offier of mediation might be made by powers, strangers to the dispute, on their own initiative, even during the course of hostilities, and that the exercise of this right should never be regarded by any of the parties to the conflict as an unfriendly act. These stipulations denoted on the part of their authors the possession of an intelligent and practical understanding of the nature of international relations and tended to enlarge the opportunity for the exercise of the mediatorial function.

\section{ARBITRATION}

The term arbitration, in private law, is often used to denote an extra-judicial, or even an extra-legal, proceeding of a conciliatory nature. This is not and never has been the meaning of the term in international law, and 
international arbitration never has been understood or practiced in this sense. The signatories of The Hague Convention were altogether justified in including in its stipulations the declaration that "international arbitration has for its object the settlement of differences between states by judges of their own choice, and on the basis of respect for law"; and in conformity with this declaration they consistently "recognized" arbitration as "the most effective, and at the same time the most equitable, means of settling disputes" of a "legal nature" which diplomacy had failed to settle.

The supposition that international arbitrators have shown a tendency to make diplomatic compromises, that they have failed to apply legal principles and to give weight to legal precedents is entertained, we must assume, by those who have not comprehensively studied the actual record of arbitral proceedings. No doubt the utterances and complaints of disappointed litigants have also contributed to produce misconceptions. There is a common saying among members of the Bar that if an attorney loses his case he is hardly to be censured if he gratifies his sense of disappointment by railing at the court.

In reality there is manifest, among some of those who discuss the subject, a tendency to misconceive and overrate what is called the "judicial" element in the conclusions of municipal courts, as well as to misconceive and overrate the element of "compromise" involved in the conclusions of international arbitrators. While the decisions of international arbitrators, like the decisions of municipal courts, have the character of final judgments, and are in this sense alike "judicial," we are safe in affirming that there is no such thing in the affairs of men as purely "judicial" deliverances, based on "pure law," without any element of compromise. Such things are not of this world. Why do courts divide? Why do judges dissent? Why does the single judge hesitate and reserve his decision, and, when he eventually renders it, confess the doubts that have troubled him and have rendered the re- 
sult uncertain? The answer to these inquiries is found in the fact that such are the processes of human thought. Our conclusions represent the anxious balancing of conflicting considerations and the effort, if we be honest, to give most weight to those that may seem to us to be the most meritorious. It is, therefore, no reproach to international arbitrators, nor does it impeach their integrity of purpose or the judicial character of their action, to admit that, as human beings determining human disputes, they have not been exempt from the limitations of human thought. Moreover, as one to whose lot is has fallen actually to examine the work of international arbitratrs, from the earliest times to the latest, I am prepared to pronounce unjustified the invidious imputation to them of a disposition to substitute diplomatic compromises for conclusions based on law and justice.

\section{II}

\section{NON-AMICABLE METHODS}

Writers have been more or less accustomed to group all methods short of war as "pacific". Such a division, involving a special and much enlarged use of the word "pacific," necessarily produced misconceptions, and I have therefore ventured to depart from it. I have, therefore, divided methods of redress into the two general classes of Amicable and Nonamicable, the nonamicable processes including those that do not and those that do involve the use of force.

\section{NON-FORCIBLE}

\section{Rupture of Diplomatic Relations}

As the first example of nonamicable methods I may mention the rupture of diplomatic relations. The withdrawal of diplomatic representation, unless for a cause personal to the representative, denotes dissatisfaction with 
the conduct of the government with which ordinary intercourse is thus ended or restricted. It thus indicates the existence of a state of ill-feeling which is likely to increase unless the cause of it is removed. Between nations, as between individuals, the results of continued illfeeling never can be confidently foretold. There is also the possibility that they may lead to exasperation, and that under the stress of nervous tension blows may be exchanged. While such results may not occur, it is not wise wholly to exclude it from the range of possibility.

\section{RETORSION, RETALIATION}

Retorsion has been defined as "the appropriate answer to acts which it is within the strict right of a state to do," but which, if not indicative of a spirit of unfriendliness, places the citizens of foreign states under special and injurious disabilities. If the foreign states whose citizens are thus injured replies by imposing similar disabilities, this is called "retorsion". Retorsion may, therefore, be called retaliation in kind. It is employed largely in matters of commerce, specially where deferential or discriminating duties are imposed on the citizens, the vessels or the produce or manufactures of the foreign state.

We distinctively use the word retaliation where the countervailing measure exceeds the injury which it is sought to redress or to stay. The range of retaliation is not precisely defined. It may take the form of menace or actual use of force, and in its latter aspect brings it within categories hereafter to be discussed.

In the early international relations of the United States much was heard of measures of embargo and non-intercourse. Both these measures may be regarded as falling under the head of retaliation.

By Joint Resolution of Congress of March 26, I794, an embargo was laid for thirty days on all ships and vessels in ports of the United States bound for any foreign port or place. The immediate cause was the British Order in Council of November 6, I793, restrictive of maritime 
commerce. On April I8, I 794, the embargo was extended to the 25 th of the following month, and by an Act of May 22, I 794, the exportation of munitions of war was prohibited for a year, while their importation free of duty was authorized for two years. This condition of things was brought to an end by the Jay Treaty towards the end of 1794 .

The same retaliatory device was revived by Jefferson, under whose presidency a law was passed on December 22 , I807, forbidding the departure of vessels from the United States, foreign vessels being allowed, however, to depart either loaded or in ballast on receiving notice of the act. This measure was intended to redress and to prevent the injuries inflicted on American commerce under Napoleon's Berlin Decree of November 2 I, I806, and the British Blockade Decrees and Orders in Council.

The embargo was eventually repealed by the Act of March Ist, I809, which substituted a policy of non-intercourse. These measures of embargo and non-intercourse may be considered as precursors of the War of I8I2.

\section{FORCIBLE \\ Reprisals}

Reprisals, says Vattel, are used between nation and nation in order to do themselves justice when they cannot otherwise obtain it. Thus,

"If a nation has taken possession of what belongs to another; if it refuses to pay a debt or repair an injury, or to make just satisfaction, the latter may seize what belongs to the former and apply it to its own advantage, till it obtains full payments of what is due, together with interest and damages, or keep it as a pledge till the offending nation has made satisfaction. The effects thus seized are preserved, while there is any hope of obtaining satisfaction or justice, but when hope disappears they are confiscated and then the reprisals are accomplished." 
This is a vivid picture of reprisals as they have usually been conceived.

In former times it was not uncommon for a sovereign to authorize his subject forcibly to seek and obtain his own redress. For this purpose he issued to his subject what was called a letter of reprisal. Such letters were issued even in times of nominal peace, but the use of them necessarily tended to obscure the distinction between peace and war. For this reason the granting of letters of private reprisal fell into disuse more than one hundred years ago, and the reprisals that have been made during the past century have been national measures carried out by national agencies.

As reprisals involved the employment of force, they necessarily tended to result in war, and if we examine the history of reprisals we find that they usually resulted in war where the nation to which they were applied was physically able to resist.

An early example of this tendency, exhibiting a blend of private and of public reprisals, is narrated by Ward in his History of the Law of Nations (I795), I 294-296. Although some of the details are amusing, the results were most serious and perhaps we may say that in this regard the affair was rather human. According to Ward, in I 792 two sailors, the one Norman, the other English, quarrelled in the Port of Bayonne and began to fight with their fists, and the Englishman being the weaker is said to have stabbed the other with his knife. The local magistrates failing to intervene, the Normans applied to their King, who authorized them to take their own revenge. This they did by putting to sea and seizing an English ship, some of whose crew they hung up to the masthead, together with some dogs. The English instantly retaliated; two hundred Norman vessels scoured the English seas hanging all the seamen they could find, while the English seized the Normans and put them to death without quarter. "The affair then," says Ward, "became too big for private hands, and the governments interposing 
in form, it terminated in that unfortunate war, which by the loss of Guienne, entailed upon the two nations an endless train of hostilities till it was recovered."

It would exceed the limits of my time and space to narrate examples of reprisal during the past hundred years, such as the famous case of Don Pacifico, the proceedings against Mexico in I86I resulting in an attempt by the French to set up an empire in that country, and various other instances the history of which may readily be found in the books. There is one case, however, to which I desire particularly to advert because it has so often been misconceived and mistaken. I refer to the bombardment of Greytown by the U. S. S. Cyane in July 1854. This case has been cited as a precedent for the occupation by the United States of Vera Cruz in 19I4, but no citation could be wider of the mark. When Greytown was bombarded, the community, as it was called, was not definitely under the jurisdiction or subject to the control of any recognized sovereignty. "It did not," said President Pierce in his annual message of December 4, 1854, explaining the action of the United States, "profess to belong to any regular government, and had, in fact, no recognized dependence on or connection with anyone to which the United States or their injured citizens might apply for redress or which could be held responsible in any way for the outrages committed." There is more in President Pierce's message to the same effect, but it is useless to make further quotations since the passage cited clearly states the point that the Government of the United States justified its action on the ground that it was dealing with an organized political society, to which competency to exercise the rights and to discharge the obligations of a government is imputed.

\section{PACIFIC BLOCKADE}

To "pacific blockade" I give a separate heading without intending to intimate that the subject is entitled to an independent classification. Different opinions have been 
expressed as to the nature of the measure, and indeed as to whether it may properly be admitted to exist; but this difference may be due to the combination of words in the title; the word "blockade" having been used to designate a well-recognized belligerent operation. Nor does the word "pacific" fortunately qualify a measure of open force and coercion. But, if we close our eyes to the inappropriateness of the words and consider the nature of the process, we may see that we have, under the title "Pacific Blockade," merely a form of reprisal. Reprisals, although classified as a measure short of war, in the sense that they do not proceed upon the assumption of the present existence of the legal condition of things called a state of war, are not otherwise "pacific"; and so with pacific blockade. If the measure is not extended, as is belligerent blockade, to the citizens, vessels and property of third powers, it presents nothing exceptionable from the legal point of view, so long as reprisals continue to be acknowledged as a legal process.

Calvo cites, as the first example of pacific blockade, the action of France, Great Britain and Russia, in I827, in obstructing access to the coasts of Greece, where the Turkish armies were encamped, the representatives of the three powers continuing to assure the Sultan of their friendship, and to declare that peace was unbroken, although the measure they adopted served to paralyze his armies. In June, I831, a French fleet, in order to obtain reparation for injuries done to French subjects in Portugal during the reign of Dom Miguel, "blockaded" a number of points on the Portuguese coast and captured a large number of Portuguese ships. A state of war did not ensue, and on July I4, I83 I, a treaty was promptly concluded by which reparation was promised to French subjects, while all Portuguese ships of war and of commerce that had been captured by the French fleet were restored. In I833 France and Great Britain, with a view to compel the assent of the Netherlands to the recognition of the Kingdom of Belgium under the treaty of London, 
blockaded Dutch ports, and a state of war did not follow. In 18.38, however, when France instituted a pacific blockade of certain Mexican ports, the Mexican Government, resenting the act, declared war, and expelled French subjects from its territory. On the other hand Mexican menof-war as well as merchant vessels were seized by the French, and the fortress of San Juan d'Ulloa was reduced. The quarrel between the two countries was terminated by the treaty of March 9, 1839, by which it was agreed to submit to a third power the decision of the questions (I) whether Mexico could claim restitution of the Mexican ships of war captured by the French after the surrender of the fortress of Ulloa or compensation therefor; (2) whether indemnities could be claimed for Frenchmen who had been expelled from Mexico; and (3) whether Mexican ships and cargoes sequestrated during the blockade and subsequently captured by the French in consequence of the declaration of war ought to be considered as legally acquired to the captors. The Queen of Great Britain, who was chosen as arbitrator, decided on August I, I844, that, after the departure of the French plenipotentiary from Mexico, followed by hostile operations on the part of the French against the fortress of Ulloa and the Mexican fleet, and the actual declaration of war by the Mexican Government, and the expulsion of French subjects from its territory, there was a state of war between the two countries, and that neither restitution of the vessels and cargoes mentioned nor the payment of indemnities could be exacted.

One of the most interesting as well as most picturesque cases of pacific blockade is that which the British Government conducted against Brazil, in the sixth decade of the last century, on a demand for reparation for the plundering of the British barque Prince of Wales on the Brazilian coast in 1861 , and a further demand for redress for what was termed an outrage on three officers of the British man-of-war Forte by the Brazilian guard at Tijuca Hill, near Rio de Janeiro. As the British de- 
mands were refused, the British admiral instituted a pacific blockade of the port of Rio de Janeiro, and seized and detained five Brazilian vessels as an act of reprisal. It was subsequently arranged that the claim in the case of the Prince of Wales should be paid under protest and the captured vessels released, the Brazilian Government assuming responsibility for any losses which might have resulted to the citizens of third countries, and that the case of the Forte should be submitted to arbitration. As arbitrator, the parties chose Leopold I, King of the Belgians. The so-called outrage began with the arrest by the Brazilian guard, at Tijuca Hill, of three officers of the British admiral's flag-ship, the Forte, these officers being a lieutenant, a mid-shipman, and the chaplain. It appeared that these officers, at seven o'clock in the evening, as they were passing the police guard-house, on their way down the hill, were accosted by a sentinel, who advanced and inquired as to their identity. Here the accounts begin to diverge. On the part of the British it was alleged that the action of the Brazilian police was aggressive and violent, particularly with regard to the chaplain, and that all three officers, besides having been treated with great brutality, were incarcerated over night under circumstances of peculiar indignity. The Brazilian Government, on the other hand, represented that the complainants had dined at a certain hotel, where they had "two bottles of Bordeaux and one-half bottle of cognac"; that, on their way down the hill, they attempted to "unhorse an equestrian"; that, when they were accosted by the guard, they "began to strike him with their sticks," and compelled him to summon aid; that, even after they were "deposited" in the guard-house, they showed themselves "haughty and scornful"; and that, although they "were not completely drunk," they "appeared not to be in full possession of their mental faculties." These allegations, it is only just to say, the complainants altogether denied, although they admitted that the officer of the guard, when they were locked up, provided them with 
paper and with a pack of cards, and offered to one of them a bed. The demands for redress made upon the Brazilian Government were (I) that the ensign of the guard be dismissed from the service, (2) that the sentry who was said to have begun the attack be adequately punished, (3) that an apology be made by the Brazilian Government, (4) that the chief of police of Rio de Janeiro be publicly censured for certain acts prior to the complainants' release. On June 18 , I863, the arbitrator rendered an award, in which, after reciting the proofs submitted by the parties, held that, in the manner in which the Brazilian laws were applied in the case, there had been neither premeditated nor actual offense towards the British Navy. It should be stated that, after this decision was rendered, the British Government sent a representative on special mission to Rio de Janeiro to express regret for the circumstances under which the friendly intercourse between the two countries was suspended, to disavow any intention to offend the dignity of Brazil, and to propose the renewal of diplomatic relations. The Emperor received these assurances with an expression of satisfaction; diplomatic relations were restored, and the incident was ended.

Further examples of pacific blockade may be found in the books, and in this relation I would particularly commend a late edition of Hall's work on International Law. and Holland's Studies in International Law. Both these eminent authorities reached the conclusion that, so long as the measure is not extended to the prohibition of access to the citizens, vessels and property of third countries, no valid objection can be made to pacific blockade as a measure of reprisal.

\section{WAR}

Much confusion may be avoided by bearing in mind the fact that the term war is used in two senses, comprehending (I) acts of hostility, or war de facto, by one nation against another without a formal declaration, and (2) the 
legal condition of things called a state of war, in which the parties prosecute their claims avowedly as belligerents.

Nothing could be more unfounded or more misleading than the supposition that a government cannot be said to commits acts of war, or to make war, unless war, or a state of war, has been declared or otherwise admitted to exist. Whether the acts of a government are to be deemed acts of war depends on their nature and not on what it may see fit to call them. When one government prosecutes its claims against another government by force, it commits acts of war, even though, as in the case of reprisals, a declared or avowed state of war may not have supervened, and hence we find that the Constitution of the United States, in reserving to the Congress the power to declare war, also expressly reserved to it the power to authorize reprisals. In 1883 the project for the building of a tunnel under the English Channel, to connect England and France, was killed by the publication by Lieut. Col. Maurice, then of the British War Office, of his small volume entitled "Hostilities Without Declaration of War," in which he showed that in the hundred and seventy-one years, from I700 to 1870 , inclusive, in the almost innumerable wars that had taken place, there were less than ten clear cases of a "declaration of war" prior to hostilities, although, when a state of war was eventually declared or admitted to exist, it was held to relate back to the commencement of hostilities. It may be superfluous to say that, if two nations declare war against one another, the legal condition of things called a state of war then comes into existence, although no actual force whatever may as yet have been employed. On the other hand, force may be employed by one nation against another, as in the case of reprisals, and yet no "state of war" may arise. In such a case there may be said to be acts of war, but no state of war. The distinction is of the first importance, since, from the moment when a state of war supervenes, third parties become subject to the performance of the duties of neutrality as well 
as to all the inconveniences that result from the exercise of belligerent rights.

In treating of war we may at once exclude the subject of private wars, which are no longer recognized, and may confine our attention to public war.

\section{LIMITED WAR}

Writers have been accustomed to speak of two kinds of war, "perfect" and "imperfect." The former described the condition in which the whole nation is said to be at war with another nation and all the members of each are authorized to commit hostilities against all the members of the other in every case permitted by the laws of war; the latter, the condition in which hostilities are limited as to places, persons, and things. For the terms "perfect" and "imperfect," I have ventured to substitute the terms general and limited. To ascribe to war perfection, unless indeed it should result in utter annihilation of one of the parties, seems inappropriate, while, to ascribe to it imperfection for falling short of that goal, might justify the reproach of inhumanity. In reality, limited war is war, and is as nearly perfect as any other kind, as far as it goes.

One of the best-known examples of a limited war, which happens to be furnished by our own history, is the condition of things which existed between the United States and France from I798 to I80o. Engagements took place at sea, vessels were captured, and prisoners were taken. In the case of one of the captures (Bas v. Tingy, 4 Dall. 37), the Supreme Court of the United States held that, as Congress had raised an army, stopped all intercourse, dissolved all treaties, built and equipped ships of war, and commissioned privateers the two countries were "in fact and in law at war"; that an American vessel fighting with a French vessel, to subdue and make her a prize, was "fighting with an enemy accurately and technically speak- 
ing"; and that the provisions of the law relating to prizes made in war were applicable to the case.

\section{GENERAL WAR}

General war is not limited as to places, persons, and things, but authorizes all acts permitted by the laws of war against the enemy's state and its members. It may be said that, in this sense, war is merely general reprisals carried on by states which have resolved to conduct their contention by force.

In considering the cases in which the use of violence against persons or property may or may not be permitted by the laws of war, we are confronted with two theories of the nature of war. According to what we may call the original theory, all persons belonging to the enemy, including women and children, may lawfully be attacked and killed and their property destroyed. This comports with what I venture to call the annihilative or extirpatory conception of the object in view. This conception is exemplified in the old rule that it is permissible, if not meritorious, to put all the inhabitants of a besieged city to the sword, to say nothing of the commendations, in earlier writers, of the use of violence against all persons and property of the enemy.

On the other hand, towards the end of the last century there was propounded a different theory, formulated in the well-known sentence of Rousseau, that war is a relation, not of individual to individual, but of state to state, and that men are enemies, not as individuals, but only as agents of the state. This theory has been formally accepted by many governments and has to a certain extent been incorporated in their legislation. It has not been accepted by the British Government, nor has it been accepted by the Government of the United States. From this circumstance we are not by any means to infer that these two governments have sought to give full effect to the earlier rule in their practice. Both have accepted and advoca- 
ted ameliorations of the earlier rule, and have advocated and accepted such ameliorations as a part of the modern law of war, just as the governments which have accepted the rule that war is a relation, not of individual to individual, but of state to state, have not consistently carried out the theory in all is logical consequences. In this way the nominal adherents of the earlier theory and the nominal adherents of the later theory have been able to a great extent to meet on common ground.

No doubt the subject which has chiefly served to keep the two schools apart is that of the liability of private property at sea to capture and confiscation. Almost two centuries ago advanced nations discarded the capture and confiscation of enemy private property on land. They did this perhaps not so much on grounds of "humanity" as on grounds of enlightened public policy, in order that men might, after the clash of arms was over, be enabled to resume the pursuits of civilized life, instead of perishing in unproductive wastes or roaming the forests, after the manner of wild animals, for food. But, because of the usefulness of ships as instruments of war, and of the relief of internal stress by foreign commerce, strong maritime powers manifested an unwillingness to abandon the capture of private property at sea, and, as the logical starting point of the proposed exemption was the abolition of the doctrine of individual enmity, they refused to accept the new theory. The statement is constantly reiterated that the United States, in 1856, proposed to the powers the abolition of the capture of private property at sea. This statement is true only in a strictly qualified sense. The United States did not propose to do away either with the law of contraband or with the law of blockade. Thus limited, the effect of the proposal, had it been accepted, would have been much slighter than is generally imagined. The history of wars, including that of the last great war, demonstrates that "measures of blockade", whatever this may mean, and contraband lists may readily be so extended as to reduce the exemp- 
tion of private property from maritime capture to negligible proportions. It is therefore evident that, if the American proposal of 1856 had been accepted, its value would have depended on the power and the will of neutrals to make it practically effective.

Wars, whether limited or general, may end either de facto or by virtue of treaties of peace. For both modes international law provides appropriate rules. Where war is not purely de facto, the rights of the parties are determined by the rule of uti possidetis; where the war ends by a treaty, this rule may also be invoked, where nothing is expressed to the contrary. It may be superfluous to remark that it belongs to each independent state, in the exercise of its sovereign rights, to decide for itself whether it will end a war in the one or the other of these two modes.

At the present moment a writer or speaker who ventures to discuss international relations seems to lay himself open to the charge of incompleteness of thought if he fails to present or to commend some proposal by which war is to be immediately and finally abolished. Whether this expectation proceeds from a desire to end the numerour armed conflicts still going on, or from a wish to preserve a fancied condition of peace which does not in fact exist, I am obliged to regard it as essentially impulsive and superficial. At a meeting of the so-called League to Enforce Peace held at Philadelphia in June, I9I5, an eminent speaker expressed disappointment that certain persons whom he named had not presented a plan for the termination of the war then raging in Europe. Much sounder was the view expressed by the late James J. Hill, when, on the outbreak of the war early in August, I914, in response to the request of a reporter for an opinion as to when the war would end, he sententiously replied: "Young man, you can ask more fool questions in five minutes than I can answer in a week. The war will end when somebody gets licked." As the war progressed in area and in intensity, orators often spoke of it as "a war 
to end war." Whether those who used such phrases have now forgotten them, it is immaterial and would be unkind to inquire. The intoxicating effects of illusive phrases are beyond the reach of prohibitory legislation. No war ever has been or ever will be fought to end all war. Wars proceed from definite, concrete causes connected with conflicts of opinion or of interest by which the passions of men are excited. The conflicts may be far less vital or important than the parties suppose them to be. They may indeed be altogether unimportant, except in the particular that they produce the nervous tension which impels human beings to resort to force. On the other hand, the differences may be of a profound and far-reaching character, such as to produce a deep sense of injustice and unrest. Whether in such conditions the tendency of men in the mass to seek their ends by violence can be restrained, is always a matter of conjecture. While threats or combinations of force conceivably may exert a restraining influence, they may also have the opposite effect, and never can be counted upon with entire confidence. The late Count Hayashi, in his Secret Memoirs (pp. 226-227), is represented as having written that the Japanese public is ordinarily rather cool, and indeed almost indifferent, toward foreign affairs, but that, when something happens to force attention in that direction, "then at once the public scems to get intoxicated, as though drunk with alcohol, and it behaves as if it were not able to discriminate". Count Hayashi need not have imputed this tendency to his own people as a peculiarity. The same tendency to get excited at the prospect of a fight, whether between dogs, between individual men, or between nations, more or less characterizes all people. When an acute international situation arises, the possibility of a physical contest at once comes into view. Sudden excitements thus spring up, and the capacity to think clearly and to reason calmly, instead of being popularly commended, may expose to suspicion and even to censure the few who still retain it. In such a condition of things, 
the precipitation of a war is not a difficult task. Wars will diminish in proportion as men, when confronted with apparent conflicts of opinion or of interest, come to think first of peaceful rather than of forcible solutions. To the attainment of this end the systematic employment of peaceful and tranquillizing methods, such as good offices, mediation, and arbitration, is necessarily helpful.

The extent to which such agencies or methods may be successfully employed may be said to depend rather upon the disposition of the parties to accept them than upon the nature of the dispute. If, for instance, arbitration has failed to prevent a certain war, it by no means follows that arbitration could not have settled the dispute to the satisfaction of the parties, if they had been willing to try it. Wars have often grown out of disputes far less serious and complicated than some of those which arbitration has actually settled. In the future, just as in the past, the preservation of peace, internal as well as external, will continue to depend on the cultivation of a spirit of justice and of toleration, and the exemplification of that spirit, by men and by nations, in their dealings with one another.

JOHN BASSETT MOORE. 


\section{"The Evolution of Private International Law"}



"THE EVOLUTION OF PRIVATE INTERNATIONAL LAW"

AN ADDRESS DELIVERED ON THE OCCASION OF THE CONFERRING OF THE DEGREE OF DOCTOR OF LAWS

ON ESTEBAN GIL BORGES, MINISTER

OF FOREIGN RELATIONS OF

VENEZUELA

(In pursuance of its plan to train the students of the School of Foreign Service not only in the theory of Foreign Service but also in its practice, Georgetown University sent a group of eighteen (18) students to Venezuela in the summer of 1920 to become acquainted with the people and to study the economic conditions of the country. This trip was a signal success, due to a large extent to the many official courtesies extended by the Government of Venezuela. Hence, when Dr. Esteban Gil Borges, the Minister of Foreign Relations of Venezuela, arrived in the United States at the head of a special mission in April, I92 I, Georgetown University conferred upon the Minister the degree of Doctor of Laws. The paper given below was read by Dr. Borges on this occasion.)

In private international law there is evolving a national tendency which has had a rather full theoretical development in these recent years, particularly in Germany and in Italy. It is, perhaps, the prevailing doctrine in the English speaking countries.

This tendency is not an exceptional fact in private international law, but it is common in the evolution of all systems of law. Private international law tends to become a law of the state just as in other times private law was 
the law of the race, in the case of the barbarian peoples, and was the law of the city in the Greek and Latin forms of society, and the law of the land in the period of feudal social organization.

At certain moments in the course of history the juridical ideals of mankind, as it exists in one or another group, are so energetically expressed that they take on the form of a legal system exclusive in character. Progress has lengthened the radius of this orbit from the ethnic unit to the city, from the city to the province, from the province to the nation. In Rome this exclusive character of the law dominates the Law of the Quirites. The law of the feudal period, in its turn, was as exclusive in nature as the Roman law of the early times. The doctrine of territorial sovereignty, absolute in character, was exclusive in a way analogous to that which had marked the effect of the Law of the Quirites on Roman institutions. In Rome, there was the exclusiveness of the city as against all that lay without, while within the city there was the exclusiveness of the patrician class as against the plebeian class. In the middle ages, the attitude of exclusion was that of the feudal estate on the one hand as against all that lay outside, while within the unit of sovereignty the law of the lord was exclusive as against that of the vassal.

Civil law was, in the cities of Greece and Rome, the element which fused the antagonistic interests of classes and castes into a social unit more embracing than that of the tyrannies, despotic monarchies and military oligarchies of the Orient. The national law in modern times was, in turn, the element which fused into a still more inclusive unity,- that of the State,- the antagonistic interests of the provinces as they had existed during the feudal period.

In Rome the city limit was the frontier of law. The law was the child of the city. The foreigner was the enemy. The city was juridically a community isolated within its hills.

In the society of the middle ages there was, as in Rome, 
a certain antagonism operating within each social group. The feudal castle and medieval town were as hostile to each other as had been the patrician and plebeian classes in Rome, but over and above this hostility prevailed the hostility against the foreigner. The doctrine of territorial sovereignty was, as we have said, the Law of the Quirites, translated into terms of feudal law.

Periods of time, often centuries long, were necessary in order that progress should break down these boundaries limiting the effect of law set up by the caste, the race, the city, and the feudal estate, in turn. In Rome, the political work of the Empire, the philosophical contribution of Stoicism, the spiritual reform of Christianity, were necessary to bring about the transformation of the Law of the City into the Law of Nations. In our modern times the political achievement of monarchy, the philosophical influence of the Natural Law School and the grinding process of revolution were all required to change the law of the province into the law of the nation.

The social forces which transformed the categories of human society likewise transformed its law. Rome experienced a profound modification in its legal ideas when those social forces made of the City of Quirites the Republic of the Praetors and Tribunes, and then, later, transformed the Republic into a cosmopolitan empire.

Legal categories have suffered a like transformation at the beginning of our modern period. Analogous to the reaction against the principles of feudal society is the reaction in law, particularly in the field of private international law. One of the manifestations of this reaction was that of the theory of statutes. The glossators who formulated the statutory theory were the heirs of Latin tradition.

The legal theories of Italy were the children of Roman cosmopolitanism.

Legal ideas and influences have roots not only in the loose surface earth of theories, but they also have roots deep in the historic subsoil of the Western races. These 
ideas and instincts are the result of an historic evolution which has at times lasted centuries. In the middle ages we have seen the countries of the Roman Law develop in the direction of the personality of law, while those which lay outside the influence of Latin civilization developed rather towards the territorial concept of law. Later, we have seen two other elements in conflict: on the one hand, the legal customs of feudalism, and on the other, what was left 'of the legal system of the invaders. The fundamental principle of the one was territorial sovereignty, while the key of the other was the law of the race. The two principles carried on a long struggle, and historical conditions determined the victory in each instance.

France and Germany were feudal countries and they were controlled by the system of territorial sovereignty. Italy was a country of small republics, organized municipally and saturated with Latin traditions; and Italy was dominated by the theory of the glossators. Roman law and local customary law were locked in this great struggle. The institutions of society swung now towards the imperial idea, that is, the idea fundamentally Roman, and now towards the feudal idea, fundamentally the product of the individualistic spirit of the Germanic Race. The systems of private international law survive all the incidents of this mighty struggle, from which, as a sort of compromise formula, there emerged the statutory theory. But this harmonizing formula had still further to adjust itself to the social conditions of the nations, and from it there arose in turn systems so different in character as that of the Italian jurists of the thirteenth century, that of the French jurists of the sixteenth century, and that of the Dutch jurists of the seventeenth century. The doctrine of Bartolo is altogether different from the theory of Dumoulin and D'Argentré, and this, in turn, differs from those of Voet and Huber. In this connection Laurent was able to say, "There is no vestige of the cosmopolitanism which characterized the glossators to be found 
among the statutory theorists," and, again, that "The statutory jurists are already French, Belgian, German."

The reason for this difference in interpretation of the same system of law is to be found in the controlling ideas which characterized each of the peoples, and also in the diversity of their social institutions. Law has been profoundly affected by social conditions and mental aptitudes. In Italy, which was a country primarily municipal in its social structure and fundamentally Roman in its juridical development, the dominant theory was that of the glossators. In France, on the other hand,-a feudal country, the land of the coutumes, - the prevailing law was the law which ran with the land, although there was discernible an occasional tendency towards adoption of the Italian system. Again, in the Netherlands and Belgium, which were countries of provincial autonomy, the governing principle in law was that of absolute territoriality.

The transformation of the doctrine of personality of law is another example of the profound modification by which experience shapes ideas which may have had the same source, and, at the outset, the same nature. The idea of the personality of law has in our modern systems of law the same function which it had in the early centuries of the middle ages among the invaders of the Roman Empire. In both systems of law, the function seems to have been identical although the ground for its operation seems to have changed.

Lainé and Laurent have denied that these two systems had an identical origin and a close relationship. "We must not," says Laurent, "confuse the personal law of the Germanic peoples with the personal law or statutory law of French legal theory. In our system, one law governs all those who are members of a single state. The Code Napoléon governs all Frenchmen whatever may have been their racial origin. Generally speaking, laws are without authority beyond the boundaries of the territory

${ }^{1}$ Laurent-Dr. civ. int. I-257-258. 
over which the legislator exercises jurisdiction. Some laws, however, which deal with the status and capacity of persons continue to govern even Frenchmen living in foreign lands; and these laws are called personal because they refer to the person and no Frenchmen can escape them by departing from his native land. ... Among the barbarian peoples the personal law was the national law of every man." "The personal laws of the French," remarks Lainé, "are nothing else than their territorial laws following them into foreign countries. Today all laws which are called personal from the point of view of conflict of laws are really territorial laws, that is to say, they are precisely the opposite of the personal laws of the barbarian peoples."

The basis of the notion of personality of law has, in fact, been transformed. Among the barbarians the criterion was the race, while in modern law it is territorial. Its function, however, in our judgment, remains the same, and in one and the other case to a greater or less extent it implies the application of a national law in a foreign country. Among the barbarians it was the law of the tribe while among the peoples of today it is the law of the nation. What has changed is the form of the State; the basis of law in the system of the invaders was the ethnic unit, while in the modern world it is chiefly the geographic unit.

Neither the personality of law among the barbarians nor the territoriality of law in feudal Europe, nor the compromise formulas of the statutory jurists, nor again the personality of law in our modern juridical system can be conceived as purely theoretical notions capable of isolation from historical realities. These concepts take their origin directly in the diversity of social institutions, racial characteristics and stages of evolution of the States. The personality of law directly corresponds to a notion of a state resting squarely on an ethnic unit; the "law of the

${ }^{1}$ Laurent, Dr. civ. int. I-168. 
land rests, in turn, on a concept of a state founded on the basis of a geographic unit; while the personality of modern law finds its basis in a theory of the state resting on the principle of nationality.

The work of centuries cannot be changed in a day. The personality of law is destined long to remain an element in the legal systems of those states which accepted the Roman law and the Latin theory of the State; the territorial character of law will likewise remain imbedded in the legal systems of those States which adhered to the Germanic law and the feudal relations.

Race, historical environment, ideas, instincts, prejudices, political interests, national passions,-all these are coefficients with evident influence on the formation of law and in a less direct, but none the less certain manner on the formation of scientific doctrines. In order to estimate the possibility of a reform which would bring about a uniformity of ideas in the teaching and principles of positive law, we must take account of the historic factors. Scientific thought by itself would create nothing but abstract concepts. For example, if we were to try to reconcile the Italian theory of the personality of law and the territorial theory which prevails in the English speaking world, we should have to wipe out all the past of these peoples and erase from the national life of some, centuries of feudal traditions, and from that of others, centuries of Roman traditions.

In private international law we find essential differences between the countries of the civil law and those of the common law, and these differences originate in large part in the historic development of these two systems of law.

"Our English concept of the law," says Harrisson, "preserves us from the fantastic sophism which govern most of the law on the Continent, that is to say, the idea that from international private law we can construct a universal system based on the meditation of juries and imposed by the force of the logical strength on the different tribunals of Europe. For us in Eng- 
land, notions of jurisprudence are derived from practical decisions and not dogmatic theories."

"Systems of legislation," says Lainé, "may be divided into two groups; on the one hand, the system which exist in France, Italy, and Germany, and on the other, the systems of England and America. The first group has as its common element the Roman law, which cannot be found in the second; conversely, the second group has the feudal law, which is not to be found in the first. Consequently, between these two systems of legislation there is a profound difference for a double reason."

The positive law of the United States has been composed by jurisprudence and federal legislation. In matters of private international law, Anglo-American jurisprudence still clings to the concepts of the Dutch jurists of the eighteenth century. The doctrine of absolute territorial sovereignty permeates its rigorous attitude towards the foreigner and the foreign law.

The application of the foreign law is not admitted, but it is tolerated on the basis of comity and as a matter of liberalism. ("Ex comitate"; "Liberaliter"; V. Comm. ad Pandectas Lib. I-T. IV- "De Statutis.")

The theory of the "Lex Situs" is the basis of the private international law of the English speaking peoples. This theory is applied to all juridical relations, persons, status and capacity, property and all its ramifications, contracts and criminal law.

"It is of the highest importance," says Minor, "that every question coming to a court for decision shall have a 'situs' somewhere, and, generally speaking, every question which arises will be settled by the law of the State where this 'situs' is located. Whatever interests may be ventilated before a tribunal, whether they have been created by the voluntary action of an individual or have an origin without his voluntary action but rather as a

${ }^{1}$ Harrisson, Journ. de Dr. Int. Privé, 1880, p. 548. 
result of the operation of law, such an interest must have its 'situs' indicated by the individual or determined by the law. Marriage, contract, inheritance, and crimeeach of these things has its 'situs,' and it is the law of the 'situs' which governs it. ... One of the principles of science is that every state is sovereign within its own jurisdiction. Consequently, every state may forbid the application of foreign laws within its boundaries. It follows that when effect is given to a foreign law it is because temporarily the national law withholds its supreme authority in favor of the foreign law, which, for the moment and with particular reference to a specific case, is converted by the will of the State into its national law."

In the British Empire the difference between the juridical standards of the home country and the constituent States of the Empire, and in the United States, the difference between the federal and state laws, has resulted in a tendency somewhat similar to that which prevails in private international law; and these differences have conferred predominating influence on the theory of territorial sovereignty.

These differences, profound in character,-which distinguish systems of private international law prevailing on the European continent and in England,- -and the differences between the civil law of the Spanish American countries and the common law of the United States in America, are to be attributed less to the fondness of thinkers for this or that theoretical construction, than to peculiarities in the historical development of the respective juridical standards.

After the dissolution of the Roman Empire, the variety in law, based on the criterion of race, persisted. From the eleventh through the twelfth century, the commercial relations and the renaissance of Roman Law in the cities of Italy modified the concept of law in the units of civil society which there existed. As Westlake remarks, in the

${ }^{1}$ Minor, Conflict of Lawes, Boston, 1901, p. 6. 
application of foreign laws, principles of justice, determined by reason, were observed. ${ }^{1}$

The feudal system brought to the Western World a new concept of private international law. ${ }^{2}$ This fact was the starting point for two distinct systems of law on the Continent. According to one, the law of the land was to be applied to every controversy, while according to the other, there could be applied to a particular case a foreign juridical principle if the nature of the case so required.

By reason of the geographic isolation of England and the unity of its judicial organization, that country was somewhat remote from this conflict of legal systems. The Norman conquest resulted in the organization of a strong monarchy and a parliament with genuine legislative authority. As Brunner declares, the Curia Regis from the beginning displayed an unaccustomed capacity for centralizing the legal and administrative system of the country. ${ }^{3}$

These elements constituted a uniform and exclusive system of territorial law, a closed system in which there was no room for the variety of points of view given expression by French, Italian, Dutch and German jurisconsults in settling conflicts between their several customary or statutory systems.

Anzilotti puts it well when he says: "In England, the statutory theory was late in coming into use, and it was adapted in such a way to the common law that it was almost transformed. In all the other countries on the Continent the principles and conclusions of this theory were admitted. It is true that they were regarded from different and even opposite points of view."

England remained in this geographic and legal isolation down to the period of revolution. At the end of the sixteenth century the commercial relations between Eng-

1 Westlake, International Law, 4th Ed. p. 15.

2Sumner Maine, Ancient Law, p. 108.

'Brunner and Hastings, Sources of the Law of England. 
land and the Continent grew very much more close. This was particularly the case between England and the Low Countries. The Dutch publicists of the school of Grotius, Rodemberg, of the two Voets, and of Huber, enjoyed great prestige.

English jurisprudence found its doctrines particularly applicable to the legal system of England, and as application of foreign law was regarded as a limitation of territorial sovereignty, this obstacle was overcome by the acceptance of the principle of comity of nations.

The comitas gentium is still in England and the United States the basis for the application of foreign law. British jurisprudence and that of the United States have been in this regard altogether conservative. In I895, a decision of the Supreme Court of the United States declared that the principle of reciprocity was an indispensable requisite for the carrying out of foreign decisions for "the comitas gentium of the United States called for nothing more."

Recently there has developed a tendency looking to the conciliation of the two systems of private international law, namely, to that of Europe and to that of the English speaking countries. The Conference of the International Law Association, at its meeting in Heidelberg in I9II, declared "that there ought to be established an International Commission with a view to recommend mutual concessions between the systems of law of the continent and the English speaking peoples so as to bring them closer to uniformity."

The difference in the basis of international law between the countries of Roman tradition and those of feudal traditions are not so profound as to compel us to abandon our hope of reaching a compromise which will eliminate the divergencies. National peculiarities which took shape by reason of racial differences are today of less influence than they were in the evolutionary period of law, while

${ }^{1}$ Cf. Beale, Harvard Law Reviezv, 23; Wharton, Conflicts of Law. 356-357; and New York Code of Civil Procedure, Par. 1756. 
those peculiarities due to geographical reasons have been modified by reason of the improvement of communications and means of closer contact between peoples; while, finally, those due to differences in social institutions are being gradually wiped out by reason of the expansion of a single ideal of civilization which makes identical the principles of moral and juridical life. ${ }^{1}$

The action of various common cultural factors, the comparative studies of legislation which seek amid all the varieties those elements which are common, and which always exist at the bottom of all systems of law, and upon which there may be based a harmonizing structure, research in the universal underlying stratum of ideas and principles governing our civil life, and, above all, the analogy of the interests which nationalities in this hemisphere have in their various juridical relations and particularly in commercial law; - these factors seem to justify our hope and to stimulate our effort in the unification of the legal standards of America.

The most imperative need of legislative uniformity,and the least difficult to effect,-is to be found in the field of commercial law. The work of uniformity in this branch meets fewer obstacles than in the other branches of law, as the civil or public law more immediately and fundamentally follows the influence of national individualism and historical tradition.

Commercial institutions fulfill economic requirements of a general character; it is, therefore, in this branch of legal activity that the task of making uniform the law of the American Republics can most successfully be achieved. This will be a useful accomplishment. This work of uniformity will not only be useful now, but it will also clear the way, in the future, for a more embracing and more profound unity of the juridical life of the nations of this hemisphere.

\footnotetext{
${ }^{1}$ Bertin-Journ de Dr. Int. Privé, 1892-225, and 1898. For the opposite view, see Raoul de la Grasserie. Raymond Saleilles, Rev. trim. de Dr. Civ.
} 
The President of the University, in introducing the next speaker, said :

"I believe the greatest force in the country today for the promotion of harmonious intercourse among nations is the Pan American Union. It is always ready to furnish accurate historical knowledge of all the countries of America, and it is likewise always ready to correct false history concerning those countries. It seems that a man to be a successful Director of that Union should possess one of the qualities of a great poet. He has to be born to such a position and cannot be made. The Union at present has a man at its head who certainly seems to be born for the position. He has a wide knowledge of the American Republics, a broad sympathy with their peoples and a geniality which is irresistible. It gives me great pleasure to present him to you this evening in the person of the Honorable Leo S. Rowe, Doctor of Laws, Director of the Pan American Union."

Closing Remarks by the Honorable Leo S. Rowe,

$$
\text { LL.D., }
$$

Director of the Pan American Union.

Gentlemen of the Special Delegation from Venezuela, Memibers of the Board of Regents and Faculties of Georgetown University, Students of Georgetown University, Ladies and Gentlemen:

One would be poor both in mind and spirit were he not to be stirred by an inspiring occasion such as this. It is on these occasions that we are able to measure the progress that has been made for that closer relationship, not only between the governments, but between the peoples of America, which means so much to the present and to the future of our civilization.

It is, therefore, Mr. Minister, with a deep sense of privilege that I bring to you the warm greetings and congratulations of the Pan American Union. 
We realize that in honoring you Georgetown University has honored itself. We greet you as the representative of that spirit of continental co-operation which both you and your country have done so much to develop. Statesman, philosopher, educator, you have ever held before your students and before the people of your country the highest standards of international right and justice. Beyond the personal tribute which this occasion means to you, Sir, we desire to thank you and the members of the distinguished special mission that accompanies you for the honor you have done this country in paying us this visit. Your presence here means much to us, as it means much to the other republics of the American continent, because, aside from the great outpouring of national feeling which the occasion of the presentation of the statue of the Liberator has brought, there is a significance to these demonstrations which I am sure you will carry back with you to Venezuela, and which will also resound to the utmost confines of this continent.

The great national hero whose memory we have honored during the ceremonies of this last week stands forth in the history of this continent as the pioneer of internation co-operation, the first to appreciate the importance of unity of policy and unity of effort as between the republics of the American continent, the first to realize how much such unity of effort means to the peace of America and to the peace of the world. Bolivar's call for the assembly of the First Pan American Congress, which met in Panama in I826, indicates his large vision, his power to visualize the future and his keen sense of the important part which the republics of America were called upon to play in the history of modern civilization. The high standards which he set during the early years of the nineteenth century have required a long time of painful effort to find acceptance throughout the continent, and it is only the present generation that is beginning to reap the fruits of the great, statesmanlike vision of your distinguished countryman. 
And we congratulate you, $\mathrm{Sir}$, as well as those who are accompanying you, that it has been vouchsafed to you to continue, and to express in your own public policy those high standards and ideals for which Bolivar stood, for which he struggled and for which he made the great sacrifice.

The Pan American Union greets you, Sir, not only as the worthy representative of a great country, but as a staunch promoter of those ideals of international justice and fair dealing which should ever characterize the relations of the republics of America with one another and with the world at large. 



\section{Latin America as a Factor in International Relations}





\section{LATIN AMERICA AS A FACTOR IN INTERNATIONAL RELATIONS \\ I}

THE PHILOSOPHY OF AMERICAN HISTORY

The attempt to formulate the basic principles governing the unfolding of history has been the major purpose of every system of philosophy. Historians of every epoch have concerned themselves with the presentation of facts, not because of their interest in the happenings of a particular period, but rather for the purpose of reaching some conclusion with reference to the nature of the forces that have determined economic, social and political development.

The treatment of the history of the Latin American countries furnishes a curious and rather significent exception to the general rule. While the salient facts of their history have been presented, little attempt has been made to present a philosophical interpretation and explanation of these facts. The result is that, especially here in the United States, the history of the Latin American peoples is regarded as a succession of cataclysmic changes having little relation to one another and devoid of that larger significance which is usually given to the events of European history.

For the philosophy of American history, using the term American in its broadest continental sense, we must look to the utterances of the great leaders of thought and action. An analysis of their writings discloses two major tendencies representing two distinct schools of thought, one advocating national isolation, and the other, international co-operation, especially as between the republics of the American Continent. 
In our own history, the contrast between these two schools of thought is most clearly set forth in the writings of Henry Clay as contrasted with those of John Quincy Adams. During his entire career and, especially during the period that he served as Secretary of State, Clay advocated the closest co-operation between the republics of America. In fact, there lurked in his mind a plan which was never definitely formulated,-to bring about some form of political affiliation, or at least unity of policy between the republics of the American Continent. Adams, on the other hand, looked upon affiliation or anything approaching thereto with distrust, and regarded any such plan as a departure from the settled policy of avoiding entangling alliances. It is a curious fact that in spite of this wide difference of viewpoint, Henry Clay became Secretary of State under Adams and that the documents attributed to these two statesmen, expressing their views on this basic question of foreign policy, were issued soon after the Inauguration of Adams. ${ }^{1}$

Clay did not hesitate to go so far as to advocate an actual confederation of all the republics of the American Continent, and with a vision prophetic of subsequent efforts, proposed that this union "should wield the force of the confederated states in defense of any member that may be attacked.

"This scheme of a general confederation of the Americas," he said, " is submitted to the public as a means of securing peace and power abroad, peace and happiness at home. Every argument of humanity. policy and reason, calls upon us to rivet the bonds of fraternal affection between the inhabitants of the same continent, and to guard with a sacred vigilance against the rupture of a single link.

${ }^{1}$ See article attributed to Henry Clay, appearing in the Democratic Press of Philadelphia and reproduced in National Intelligencer, Washington, April 26, 1825; also see Register of Debates in Congress, Vol. I, Part II, page 2363. 
"A confederation alone is competent to this duty, and without it we must submit to the ordinary fate of other nations-jealousy, discord and war-whenever any nation thinks itself strong enough to wage one with impunity."

Adams, ${ }^{1}$ on the other hand, cautious and more conservative than his Secretary of State, deprecated "any departure from that cardinal principle in our foreign intercourse which distrusts and rejects alliances with foreign nations, for any purpose."

\section{II}

\section{LATIN AMERICAN IDEALS, BOLIVAR}

Long before Clay and Adams had formulated their views on American continental policy, Bolivar, ${ }^{2}$ languishing in exile, wrote:

"Above all means I desire to see formed in America the greatest nation on earth; greatest, not so much by virtue of its extent and wealth, but by virtue of its liberty and glory."

The broad statesmanlike vision, which characterized the great South American leader, led him to face unflinchingly all the political and social difficulties confronting the nascent republics of the American Continent. He realized to the fullest the obstacles which would have to be overcome before the peoples of America could develop into a truly democratic society. He never allowed his vision to be obscured by formulae or phrases, and he fully appreciated the fact that democracy means far more than a mere form of government, and that unless it has its roots in a truly democratic form of social organization the mere political expression becomes a hollow and empty form.

Throughout the thought and activity of Bolivar there

${ }^{1}$ See National Intelligencer, April 26, 1825.

${ }^{2}$ Famous Kingston letter O'Leary Memorias, XXVII, 291-319. 
is evident a deep and abiding faith, not only in the future of what he designated as the American political system, but also in the high mission which this system is called upon to perform.

The philosophy underlying his thought represents one of the two great currents in international policy. On the one hand, the policy of isolation, whose silent correlative is force, and, on the other hand, the policy of co-operation, whose purpose is "not to restrain the forces that make for war, but also to liberate the forces that make for peace."

It would be presumptuous to attempt a detailed formulation of the part which the republics of America are called upon to play in the economy of a civilization, which, until very recently, promised to be progressive. It is fitting, however, that at the close of the first century of their independence, some attempt be made to estimate the part that they are called upon to play and which they will play if their people and the governments emanating from them fully realize the magnitude of their obligations and the possibilities of their privileged position.

One of the striking characteristics of the history of the peoples of Central and South America has been their readiness and willingness to place themselves in the service of standards of international right and justice considerably higher in some instances than the standards actually disclosed by the policy pursued by their respective governments. In fact this trait has been as characteristic of the history of the United States as of the republics of Hispano-America.

At the time of the promulgation of the Monroe Doctrine, for instance, the documents of the period show that the leading statesmen of the United States regarded the promulgation of this Doctrine as necessary to the safety and untrammeled development of the republic; a measure calculated to prevent the repetition on the American Continent of the entanglements, jealousies and rival- 
ries which characterized the European international situation. To the people of the United States, however, this Doctrine meant far more than a measure of national protection. It aroused enthusiasm because of the service which it was calculated to render to the then struggling republics of Latin America. It was the native idealism of the people that prompted them to give warm support to the Doctrine, an idealism which stands in marked contrast with the more calculating principle of national interest which dominated the thought of the political leaders of the period. The generous impulses that led the people of the United States warmly to sympathize with the struggles for independence of the nations of Central and South America also led to the expression of sympathy with similar struggles in other sections of the world. In precisely the same way we find the nations of HispanoAmerica, not only warmly sympathetic, but evincing real enthusiasm for the struggles of sister nations for political and civil liberty.

We are here face to face with one of the really great problems confronting the republics of the American Continent. This native idealism of the people must be made more effective in international affairs. The surest means to bring this about is through the establishment of a closer relationship between public opinion and governmental policy; in a word to bridge that tragic gap, which has been the cause of such world disaster;-the abyss between the standards of national opinion on the one hand, and the so-called practical aims of political leaders on the other. This is the true significance of the struggle for the democratization of American foreign policy;namely, to translate into the real world of international relations, the idealism and generous impulses of the nations of the American Continent. The difficulties, while great, are in no sense insurmountable and the first step toward the attainment of this end is to assure the freest possible public discussion of every question of foreign 
policy. The real democratization of government depends not on the indefinite multiplication of elections, but rather on that constant public discussion which crystallizes public opinion and which makes such opinion effective in its control over every organ of government.

\section{III.}

\section{SOURCES OF POTENTIAL INFLUENCE}

During the century that has elapsed since the promulgation of the Monroe Doctrine, the countries of Latin America have increased in population from $25,000,000$ to $85,000,000$; their estimated national wealth (while impossible to determine accurately) has, roughly speaking, advanced from $\$ 3,000,000,000$ to $\$ 50,000,000,000$; their position in world commerce has changed from an estimated total of exports and imports of $\$ 250,000,000$ in 1823 , to a total of $\$ 5,200,000,000$ in 1920 .

These figures indicate nothing short of a revolution in their position in the economy of the world's affairs. They can no longer be regarded as the beneficiaries of the sympathy and more or less benign condescension of other nations, but have come to take their position amongst the powers of the world with all the duties and obligations which that position involves.

In order to make that position as fully effective as possible, it is important that they adopt a policy which will bring about at least three major results. First, they must endeavor to secure greater financial independence through the development of native capital, and this can only be done through the stimulation of habits of thrift on the part of the masses of the people. It is a reflection on their economic development that in spite of. marvelous resources, in spite of a vigorous and alert population, the amount of native capital that has been invested in their enterprises is comparatively small.

As long as the republics of Latin America remain 
wholly dependent on foreign capital for the development of their resources, so long will their independence of judgment and of action be limited and they will thereby be prevented from playing the part in world affairs which they are manifestly called upon to play.

This does not imply to the slightest extent any discouragement to the investment of foreign capital. It means the establishment of financial co-operation rather than the present situation of financial dependence.

A change significant of what the future has in store for us is now taking place in several South American countries where, with the combination of North and South American capital, new enterprises are being established and a new spirit of international co-operation developed.

A second step-and one of even greater importanceis the elimination of the spirit of distrust and mutual suspicion which has characterized the relations between some of the republics of Central and South America. No other factor has contributed so much toward preventing the development of anything approaching unity of continental policy. If the American republics hope to acquire a real influence in world affairs, they must eliminate from their international relations every trace of distrust by solving the international questions now pending between them. An united America is a condition prerequisite to an influential America. When in 1902, after definitely settling their frontier difficulties, Chile and Argentina solemnly agreed to a limitation of armaments, an agreement amounting practically to a naval and military holiday for a period of five years, they set an example to the entire continent, demonstrating what can be accomplished when mutual confidence and good faith become the guiding factors in international relations.

In the third place, the American Republics must make service rather than revenue the guiding principle of their 
national as well as their international policy. By this, of course, I do not mean that they need sacrifice any of their budgetary interests, or even that they are called upon to reduce the burden of taxation. The principle does, however, call for the imposition of taxes according to ability to pay rather than ease of collection, and the application of social rather than purely financial or fiscal considerations in fixing the cost of governmental service to the consumer.

\section{IV.}

\section{PAN AMERICAN CO-OPERATION}

The principle which I am here defending was strikingly illustrated in the recent International Postal Conference held at Madrid. At this world conference the contrast between the European and the American viewpoint was clearly and almost dramatically presented. European countries, in the desperate financial condition which they find themselves, are seeking every possible opportunity to increase their revenues. On the other hand, the American Republics look upon such services as postal communication in the light of a broad social service, designed to foster closer ties between different sections of the country and to bring about, internationally, closer bonds of friendship and commerce between different sections of the Continent.

The difference of viewpoint was so great, in fact, so irreconcilable, that the only satisfactory solution was the negotiation of a separate convention between the republics of the American Continent (to which Spain and Portugal were also admitted) under which the domestic rate is made applicable to all classes of mail matter between the countries parties to this agreement.

Viewed in its larger aspect, the action thus taken by the American Republics possesses a far-reaching significance, not only from the standpoint of their domestic 
policy, but also as the indication of the principle which should guide their international relations.

With the accomplishment of these three steps in their national and international policy, the republics of Latin America will be prepared fully to enter upon that larger influence which they are destined to exercise on the destinies of the modern world. Today America is the only section of the world in which the peace spirit still prevails. Signor Nitti has aptly described the situation when he said:

"What is wrong with the world is that we still keep the war spirit ; we do not cultivate the peace spirit." A description of the social conditions now prevailing in Europe even more accurate is given by one of the keenest observers of our day." "After as before the peace," he says, the temper has always been the war temper. The peace temper has never been recovered. There may be war in the world though not a shot is fired. War in action has at least the virtue; that the warmakers may affront personal perils. War in its new form is utterly despicable; the people are still drunk with the maddening fumes of war. . . Peace is not a mere suspension of fighting; . . . it is not a negative but a positive thing, worth attaining by the most laborious efforts, if needs be, worth many sacrifices. - The foolish, wicked diplomatic history of two years would nevertheless not have been possible if the soul of mankind had not been in shadow. Not only were the cornfields and the vineyards of France ravaged by the war, but the cornfields and the vineyards of the spirit were trampled under foot. The iniquities of peace are born of the war. War has destroyed elasticity of mind, independence of judgment and liberty of expression. We think not so much of truth as of conforming to the tacitly accepted fiction of the hour."

Europe stands today under the pall of a great disappointment. People have lost faith in their rulers and

${ }^{1}$ Sisley Huddleston. 
give evidence of a lassitude, and a reversion to the same standards that brought on the disaster of the Great War. As Philip Gibbs has well said:

"War to end war now mocks at us with jeering laughter. . Nationalism more narrow, more bitter, more selfish than in the world of 1914, has replaced the fleeting hope of many peoples, that there might be a real league of nations based upon the common sense of common folk. . . We have fallen back on cynicism, as nations, as classes, as individuals. There is only one cure for the woes of Europe and our own-not easy, but bound to come unless we are looking for downfall. It is the reconciliation of peoples, burying of old hatchets, wiping out of old villainies and co-operating in a much closer union of mutual help. . . Before that can happen there must come new leaders, new enthusiasm for the ideals of life, a new spirit of unselfishness and service for the common weal:-and just now, we do not see them coming."

\section{V}

THE ROLE OF THE AMERICAS

It is here that a great opportunity presents itself to the republics of America. Whether in the accomplishment of this great world mission they are to have the co-operation of the United States, still hangs in the balance, but as to the ultimate decision there can be no doubt. Even without that co-operation, they are now called upon to give to the world a demonstration of the efficiency of the principle of co-operation as contrasted with the principle of force. What Europe was unable to do, America must now perform. She must not fail, for, if she does, the last hope of mankind for a new order disappears. One cannot help but feel a glow of enthusiasm at the opportunity which now presents itself to the younger generation and which must be an inspiration to effort, combined with a high resolve that this great Con- 
tinent shall make a return to the world for the privileges and blessings that have been showered upon it.

We must ever bear in mind, however, that to fulfill this mission our domestic, as well as our international, policy must be dominated by those ideals which we inherited from the great founders of the American Republics. The governments of America must heed the yearnings and fulfill the desires of the masses of the people. They must meet the demands of millions of men and women "for unselfish purpose and fine vision; for evolution and not for revolution; for peace and not for blood."1

But, you will ask, what part is the United States to play in this new world order, if new world order here is to be? It is at this point that an important, far-reaching decision confronts the people of this country. They must decide whether their policy shall be continental or selfishly national. Our entry into the European war was a clear demonstration, if any further demonstration were necessary, that the period of America's isolation was at an end, and yet, with the close of the war, we find large sections of our people attempting the manifestly impossible task of resuming a status of isolation which no longer exists and which, in fact, could not exist, given the present economic and financial influence of this country in world affairs.

It must be clear to every student of history that unless the American people are willing to face the responsibilities which the force of circumstances has placed upon them, disaster will follow. No far-seeing vision is required to appreciate that the Americas are destined to be the steadying influence in the maintenance and progress of civilization. Both by that direct influence and by their example they must impress upon the world to an increasing degree the constructive value of co-operation,

${ }^{2}$ Francis Hackett in The New Republic, May 12, 1920. 
as distinguished from force. To the United States, this is a matter vital to the further development of our democratic institutions. Isolation means armament; it means a state of defense against every conceivable combination that may be formed, and this means a status of militarism which is inherently antagonistic to the growth of democratic institutions.

Co-operation, therefore, with the republics of Latin America in the development of a unified Continental policy is a matter of interest not only to the future of our civilization, but to the very existence of our democratic institutions. More than this-a policy of isolation means that the United States may become a disturbing factor in the world relations. Such a tragedy, and tragedy it would be, would be all the greater because of the fact that the people of this country are essentially a peaceloving people and that their present insistence on isolation is dictated in large measure by a deeply rooted desire for peace. In other words, the standards of national thought, developed more than a century ago, when isolation meant peace, have been carried into a period in which the radical change of world conditions makes this same demand for isolation a menace to America's peace and may develop into a menace to the world.

I doubt whether any other nation has ever shown quite the same capacity as the people of this country to close their eyes to the actual conditions with which they are surrounded. The choice which they think confronts them today is more apparent than real. Whatever policy they adopt will mean much to the future of the world. It is physically, morally, socially, and politically impossible for them to isolate themselves. The real question is whether, in unison with all the other republics of America, they will assume their full share of responsibility for the maintenance of the world's peace and thus create conditions favorable to the normal development 
of their own institutions and to the fulfillment of their high world mission. Any other course will ultimately spell disaster to us and possibly disaster to the world.

We sometimes discuss America as if by some inscrutable and special ruling of Providence she is to be exempt from those inexorable laws that have governed the rise and the decline of other nations. It is for this generation to divest itself of all such illusions. America will be great to the extent to which she points the way and gives the practical demonstration of a better life for the masses of her people and of a better international order as between her constituent parts. Unless she can make that demonstration, she will be recreant to her trust. To the extent, however, to which she meets the manifest requirements of the situation, she will not only be serving herself, but she will save society from the menace which now confronts it. This is the true meaning of "America first"; the true interpretation of a slogan divested of its narrow, selfish, and sordid meaning, and made the servitor of mankind.

LEO S. ROWE. 



\section{The Far East as a Factor in International Developments}





\section{THE FAR EAST AS A FACTOR IN INTER- NATIONAL DEVELOPMENTS}

\section{CHINA BEFORE CONTACT WITH WESTERN CIVILIZATION}

The great central factor in the Far Eastern situation is China. Not only is her own established civilization in itself of the highest importance, but the temper, aims and policies of this vast population will deeply affect the future development of human history.

China has but recently come into relationship with the rest of the world, and particularly with the western nations. $U_{p}$ to the middle of the nineteenth century she was a world by herself; the extent of her territories, the abundance of her resources and the completeness of her economic life made her self sufficing. She had retained a high pride in her civilization from the ages when the nations of the west were still barbarian. This tradition of superiority was preserved in Chinese thought and expressed itself in action, negatively through a refusal to have anything to do with outside nations. The Chinese constituted a great autonomous society to whom the outside world was indifferent. It was a society in which social and economic activities were all important and which cared and knew little about political action in the sense in which it was developed in the Western World.

When the merchant adventurers from the West first forced their attentions upon the Chinese they were treated merely as a local disturbance. Their presence and their activities did not make any impression on the Chinese people as a whole. Even when the merchants were followed by diplomatic agents, these too were looked upon not as the representatives of communities equal to the Chinese in importance, but as interlopers to be given as little as possible scope in Chinese affairs. It was entirely 
for the reason that a nation of political action and political organization, as it had developed in the West, was not understood by the Chinese that they were ready to commit themselves to so many undertakings that turned out to be highly disadvantageous to them. The foreign representatives were regarded as troublesome individuals, disregardful of the social consideration customary among the Chinese, given to making threats of brutal force. The Chinese negotiators, having in the past always arranged affairs by temporary compromises, which was not dangerous as long as the affairs were merely local, applied the same tactics to international negotiations, with the result that they gradually committed their government to very onerous obligations.

A dim but intense consciousness among the Chinese people that their country was being manacled led to the outbreaks of I900. This popular movement of protest was indeed originally directed against the Manchus as much as against the foreigners, but it soon was gone partly through the manipulations of the court and its anti-foreign character. The result was the establishment of co-operation among all the foreign powers interested in China for the defense of the rights acquired in the past decades. This solidarity naturally tended to fix permanently upon China all the privileges which had been gained by any one of the foreign nations. They claimed them all for their own nationals. The more liberal powers were desirous of making concessions to China and strengthening her government and preserving her independence, but were confronted by the refusal of other powers to give up any of the rights acquired. Thus, it worked out that in any controversy the determining influence lay with the power determined to make no concessions.

\section{PRESENT DAY CHINA}

Not only on account of her size and continental position, but also because of the age and quality of her 
civilization and its predominating influence in the life of the Far East, China is the essential factor in the Far Eastern situation. Through persistent reports of revolutions and other internal trouble, the outside world is apt to receive the impression that China approaches a state of confusion and anarchy, such as visited Mexico in the worst days. Yet such is not the case, and the situation is essentially different. China is just at present subject to the devastations of a great natural catastrophe holding the danger of famine and death of millions; yet aside from this natural disaster, her social and economic life is sound. The political troubles which we hear so much about are on the surface. They are squabbles between politicians and military commanders which do not reach deep into the life of the people. The normal activities of life, in agriculture, industry and commerce, go on uninterruptedly, and no matter how weak the government may be at times, the social system is strong and sound. In fact, there is today no nation in the world where fundamental social conditions are so stable.

China has at all times been non-political. In her life such impersonal, abstract ideas as sovereignty, legality, corporate existence, have not played any important part. The relationship of Chinese society have all been concrete and personal. Men have been found with a personal tie to their fathers and brothers, their wives and children, their clansmen, their teachers and the officials, in an ascending order. There was never developed a strong central administration. The union of the country was one of traditions and culture, particularly literary and philosophical rather than of legal institutions. Politically considered, it was, and still is, a loose federation of provinces, in which the localities manage their own affairs, and in which the popular loyalties are nearly all attached to local, personal and visible entities.

The tradition from this system of strong personal relationship to the impersonal ideas which underlie the Western system of law, representative government and 
corporate action, involves very radical changes. Never in history before has any nation been confronted with a problem so complex. It is because the old civilization was so permanent, so great, and so strong, that the change to new methods is so difficult.

The youth of China is at present animated with the desire to build up a strong national system, utilizing the methods of the West. The national movement, which was organized in I9I9 by students and merchants, seeks to make the ideal of national cohesion a reality. In the past, the great strength of the Chinese people has lain in the management by each local community of its own affairs, and the enormous power of tacit resistance to any unwelcome changes or demands from above or from without. In China it has been practically impossible to put through a change which the people did not accept; but the people were not organized for positive action through public opinion or through representative institutions. For the first time in Chinese history the attempt is now being made to organize a positive expression of the popular will. The actual power of government in the larger units is in the hands of the military governors of provinces. There is a struggle between this authority, resting on corruption and force, and the inherited and newly-developed desires for self-government.

China has a pacific, ethical civilization; that is, a civilization which rests not on an appeal to authority based on force, but on a universal sense of equity which expresses itself constantly in popular action, without recourse to formal tribunals. The critical question of today is, can this ethical content of Chinese civilization be preserved while national action is strengthened through the adoption of efficient methods developed in the West; or will the people of China be driven into militarism by outside aggression, and through the manipulations of the satellites and instruments of an outside militarist power? To the outcome of this great crisis America cannot be indifferent. The temper of the great 
continental nation of Asia and the character of its policy, are of the utmost moment to us. Fortunately, after a relationship with China extending over one hundred and forty years, America enjoys the good will and confidence of the Chinese in the highest measure. The problem of China is not merely one of concessions and spheres of influence, but one of the essential interests of civilization. If the just and peaceable traditions of Chinese civilization can be preserved in Asia, world peace will rest on a more secure foundation than the ingenuity of statesmen could contrive.

RELATIONS BETWEEN CHINA AND JAPAN DURING AND AFTER THE WORLD WAR

During the Great War the neighbor of China, the Japanese Empire, utilized every opportunity to strengthen her position and interests in China. Immediately after the outbreak of the war the German leasehold at Tsingtau, with a railway extending into the interior, was seized by Japan, with the initial declaration that these concessions would be eventually returned to China. In January, I9I5, the Japanese Government caused a list of twenty-one demands to be secretly presented to the President of China. The demands included both concessions of special right in certain localities and, in the fifth group, general rights of participation in the exercise of sovereign powers in China. The demands were finally enforced in May, I9I7, through an ultimatum threatening the use of force, with the exception of the fifth group which was postponed for future action.

When the United States broke off diplomatic relations with Germany the Chinese Government, in February, I9I7, decided to follow the same policy. There were no demands, promises or urgent representations, there was no haggling about advantages to be obtained. After a brief but careful consideration of the proposal of the United States, it was accepted by the free act of the 
Chinese Government. At the very time when the Chinese were making this decision, the Japanese Government approached the governments of Russia, Great Britain and France with the suggestion that it would use its influence to bring China to the side of the Allies, on condition that the German rights in Shantung were assured to Japan. China broke off relations with Germany in February, I9I7, and declared war in August, I9I7. The Chinese Government was ready to send large bodies of troops to Europe, but the transportation difficulties at the time prevented such movements. Had the was lasted longer, China would undoubtedly have become an important source of men and supplies.

After the armistice the Chinese nation entertained the confident expectation that the German rights in Shantung would not be given to any other power, but would revert to China in accordance with equity and the accepted principles of international law, China being ready to indemnify Japan for all her expenses. But the peace conference awarded the ex-German rights to Japan. China did not agree to this transfer and it is therefore not legally valid, as, by the operation of international law, the Shantung rights had reverted to China when she declared war on Germany in August, I9I7. The secret agreements made by certain Chinese officials with Japan, to the contrary effect, were not recognized by the Chinese nation, as having been made without the consent of a national representative body.

Japan being in military possession of Tsingtau and the railway, wanted to consider the award of the Paris peace conference as completing her title. The Japanese Government made a formal offer to negotiate with China for the return of the German leasehold. The Chinese Government has declined to enter into such negotiations, because to do so would be admitting the right which Japan claims and which China denies. Moreover, it was understood that the Japanese Government intended to offer the return of only the German leasehold, about one 
hundred square miles of unimportant land; retaining the highly valuable port of Tsingtau, with its steamship and railway terminals, the railway to the capital of the province, and the mining rights taken from the Germans. As these are the really important factors through which the commercial and political control of the whole province can be effected, the Chinese people are not interested in the proposal "to return the Shantung leasehold." The language used has given the impression to many that Japan had seized the entire province of Shantung, and was generously offering to return it to China. Neither Germany nor Japan, however, at any time had any right to the province of Shantung, outside of the leasehold of Tsingtau and the railway, with the adjoining mines. Should Japan retain the railway, it was apprehended that a situation would be created similar to that which obtains in Manchuria.

\section{CHINA, JAPAN, AND SIBERIA}

The joint intervention of the Allied Powers in Siberia in 1918 led to the occupation of parts of Eastern Siberia by Japanese troops, which still remain there though the other allies have withdrawn their contingents. While government is not strongly organized in Siberia, yet the authority of the government of Chita being constantly extended, and it gives promise of stability. In a measure as its power grows, it demands more insistently the withdrawal of Japanese troops from Russian soil. While the Chinese Government has not established diplomatic relations with the Siberian Government, it has found it necessary to make certain arrangements concerning commerce passing the common boundary between these two countries. The Siberian Government has expressed itself favorable to returning to China, concessions made to the Czarist Government of Russia; but such treaty revisions have of course not yet been taken up in actual negotiations. There undoubtedly exists between 
the Chinese and the Russian people an instinctive sympathy, which would be greatly strengthened and would become a very important factor, were the promises to China held out by the new governments in Russia to be embodied in actual agreements.

International joint action in China is favored by the creation of the financial Consortium, which has completed its organization and is now beginning to negotiate with the Chinese Government for financial support to be given constructive public enterprises in China, such as the building of roads, railways, harbors and canals. It is recognized that the prime need of China lies in the direction of better means of communication. Meanwhile, both locally and through the Central Government, the Chinese are beginning with their own means and in cooperation with foreign capital, to execute comprehensive improvements of this kind.

PAUL S. REINSCH. 
The United States as a Factor in the Development of International Relations 



\section{THE UNITED STATES AS A FACTOR IN THE DEVELOPMENT OF INTERNATIONAL RELATIONS}

I.

THE GENESIS OF AMERICAN FOREIGN POLICY

It is probably no exaggeration to say that no single event in modern history has exerted a greater influence upon the development of international relations than the advent in 1776 of the United States of America into the family of nations. That event was epoch-making not only because it marked the birth of a new world power, but because the principles of thought and action upon which our existence as an independent nation was justified created a new departure in theories of government. History has been described as the philosophy of hindsight. Reviewed in the light of the facts which gave rise to the American Revolution and which dictated the course of our subsequent career, no people will be found to have adhered more closely to a consistent principle of conduct both in domestic and foreign affairs than the people of the United States.

To evaluate the factors which fashioned the popular mind in 1776 , and led to the principles enunciated in the Declaration of Independence and subsequent expressions of national policy, it is necessary to take into account the origin and circumstances of colonial life in America. Groups of sturdy pioneers had hewed out of the wilderness the materials of civilized life in the face of dangers unknown to the inhabitants of European communities. The distance from the home-land, the democracy naturally created by subjection to common problems and dangers, the self-reliance and individualism induced 
by the very nature of their effort, aroused in the colonists a craving for freedom and independence. There was born in them a devotion to self-government which a sagacious mother country, under what Burke called a policy of "wise and salutary' neglect," had not sought unduly to hamper. But such measure of local political freedom as the colonists enjoyed made the more intolerable the system of commercial colonial monopoly which restricted their trade almost entirely to Great Britain, in ships of that country. The feeling of dissatisfaction aroused found nourishment and justification in the philosophy of the French disciples of the doctrine of natural rights, with its opposition to governmental and ecclesiastical oppression. With this philosophy of freedom from imposed control, which permeates the Declaration of Independence, the moral justification for political, commercial and intellectual emancipation had been found. Moreover, the colonists had been parties to practically every European war of the eighteenth century, of which they were on occasion the unwitting cause and usually the unwilling victims.

Bearing these facts in mind, it is readily apparent that the American Revolution was a protest in the name of liberty against that political, commercial and intellectual bondage which was then identified with the European systems of government. It is not surprising, therefore, that the fundamental and dominant principle of our domestic and foreign policy has been emancipation from European political systems.

It requires but slight acquaintance with history to recognize that national self-interest is the primary source of any national policy. Of its various manifestations, the instinct of self-preservation or security is the most insistent. The measures for safe-guarding this fundamental interest are likely to be dictated principally by physical conditions, notably geographical position. Foreign policy, controlled by such rigorous and unchanging 
conditions, is often likely to become intuitive, and in proportion to its success, more or less permanent. Nothing is, therefore, more natural than that the United States, with its distance from Europe and its deep-seated aversion to the European political system, should have adopted a policy of diplomatic isolation or reciprocal nonintervention.

The very success of our consolidation as a nation on this continent and the continuity of our growth in power and wealth without departure from that policy is a standing challenge to those who would, on the provocation of what seems to them a divine inspiration, and a vision of new necessities, subvert perhaps the most fundamental principle of our national existence.

Consistent as our foreign policy has been down to recent years, it has not been doctrinaire. The complete sacrifice of expediency for principle has never been a dominant characteristic of the American mind; so that an occasional variant from the constant should not unduly mislead the investigator. Bismarck once made the observation that "International policy is a fluid element which under certain conditions will solidify, but on a change of atmosphere reverts to its original diffuse condition." Doubtless the results of our last election will be interpreted by the historian of our foreign policy as a return to the constant from an attempted excursion into the variant.

Our policy of diplomatic isolation, or non-intervention in European affairs, is sometimes believed to have first received formal expression in Washington's Farewell Address, a profoundly wise legacy of constitutional proportions for the guidance of the American people. But as a matter of fact, in September, 1776 , soon after the Declaration of Independence and curiously, at the very time the proposed and greatly needed treaty of alliance with France, a variant from the constant, was under discussion, John Adams said: 
"Our negotiations with France ought to be conducted with great caution, and with all the foresight we could possibly obtain; . . . we ought not to enter into any alliance with her which should entangle us in any future wars in Europe; we ought to lay it down as a first principle and a maxim never to be forgotten, to maintain an entire neutrality in all future European wars." . . .

Yet Benjamin Franklin negotiated and signed, February 6,1778 , a treaty of commerce and a treaty of alliance with France. The fact that France sought therein to avenge her defeats by Great Britain in the Seven Years' War does not detract from the fact that the alliance paved the way for the success of the American cause, nor from our indebtedness to France, consequent thereon.

Yet the very obligations sought to be imposed on us by that treaty led, in I793, to a reiteration, in an epochmaking proclamation of neutrality, of our principle of aloofness from European wars, furnished the motives for Washington's Farewell Address, and finally caused that limited war with France from I798 to I800 which gave rise to the French Spoliation Claims. A proffered treaty of alliance with Spain, in which we undertook to attack Portugal and offered various concessions in return for political aid, but indicates, by countenancing so serious a departure from principle, how great was the need of the struggling colonists. The flexibility of the policy was again demonstrated by the readiness with which the United States undertook to adhere to the Armed Neutrality of $\mathrm{I} 78 \mathrm{O}$, proposed by Catherine of Russia.

These variants each had special motives; but nothing better demonstrates the inherently fundamental nature of our policy than the prompt return to it after momentary occasion for departure has passed.

On June I2, I783, Congress passed a Resolution which reads in part:

"The true interest of the States requires that they 
should be as little as possible entangled in the politics and controversies of European nations."

The consistency of our foreign policy is exemplified by our application of what is known as the principle of "non-intervention," which has been deemed basic in our foreign relations. John Hay once said: "The principles which have guided us have been of limpid simplicity."

In explaining the principle of non-intervention and its natural corollaries I cannot do better than quote from the masterly work of John Bassett Moore on "The Principles of American Diplomacy."

"The principle of "non-intervention," says Mr. Moore, "was used in a two-fold sense. It embraced, in the first place, non-interference in the internal affairs of other nations. In this sense, while betokening the revolutionary origin of the government of the United States, it was also intended reciprocally to concede to other nations the right to determine their form of government and otherwise to manage their domestic concerns, each for itself in its own way. In the second place, it embraced non-participation in the political arrangements between other governments, and above all strict abstention from any part in the political arrangements of Europe.

"Of the principle of non-intervention the system of neutrality was a logical derivative, as was also the recognition of governments as existing entities, and not as legitimate, or as lawful or unlawful, under the local constitution. The Monroe Doctrine itself was but the correlative of the principle of non-participation in European affairs. 'Our first and fundamental maxim,' said Jefferson, 'should be never to entangle ourselves in the broils of Europe; our second, never to suffer Europe to intermeddle with cis-Atlantic affairs.' By preserving these principles it was believed that the United States would best contribute to the preservation of peace, abroad as well as at home, and to the spread of liberty throughout the world."

The subsidiary principles of neutrality, the recognition of new states and the Monroe Doctrine will be discussed hereafter. 


\section{II.}

\section{NATURE OF EARLY AMERICAN POLICY}

It is probably a fact that the necessities of a united front in foreign relations, as exemplified, for example, in the Treaty of 1783 and the need for its enforcement, exerted as much influence as any other single factor in compelling that union of interests and charter of common action among the states of the Confederation which is now embodied in the Constitution of the United States. Foreign relations and domestic affairs have always been interdependent, and it is no accident that the great names of the founders of the country are identified as much with foreign as with domestic affairs.

The cornerstone of American foreign policy is commonly believed to have been laid in Washington's Farewell Address, although, as we have just observed, the principles of that policy were enunciated and acted upon years before that celebrated utterance. The salient paragraphs of the Address, which in the light of present events, seem prophetic, are these:

"The great rule of conduct for us, in regard to foreign nations is, in extending our commercial relations, to have with them as little political connection as possible. So far as we have already formed engagements (he refers to the treaty with France) let them be fulfilled in perfect good faith. Here let us stop.

"Europe has a set of primary interests, which to us have none or a very remote relation. Hence, she must be engaged in frequent controversies, the causes of which are essentially foreign to our concerns. Hence, therefore, it must be unwise in us to implicate ourselves by artificial ties in the ordinary vicissitudes of her politics, or the ordinary combinations and collisions of her friendships or enmities. Our detached and distant situation invites and enables us to pursue a different course. . Why forego the advantages of so peculiar a situation? Why quit our own to stand upon foreign ground? Why, by interweaving our destiny with that 
of any part of Europe, entangle our peace and prosperity in the toils of European ambition, rivalry, interest, humor, or caprice?"

While this state paper clearly indicates the American aversion to implication in the alliances and artificial ties, the balances of power and kindred paraphernalia of European political systems, Washington had no illusions that "extraordinary emergencies" might not implicate us, and for these he thought "temporary alliances" would suffice. It will be noted that the extension of commercial relations was definitely encouraged. If my judgment is correct, that the so-called "League of Nations" created at Versailles is in essence little more than a disguised alliance to maintain the balance or preponderance of power, in the time-honored fashion of European politics, then Washington's advice, the soundness of which is but confirmed by the practice of more than a century, clearly points the direction of the duty of the American people.

\section{III.}

\section{MONROE DOCTRINE}

Washington's pronouncement of the principle of nonintervention in European politics, foreshadowed its celebrated correlative of a generation later, the Monroe Doctrine. Only in the light of the background portrayed above, can the Monroe Doctrine, perhaps the most notable enunciation of American principles of foreign policy, be either understood or appreciated. Its importance for us in determining the influence of the United States on international relations and the various meanings ascribed to it as a justification for diplomatic positions assumed on occasion by this country warrant a somewhat detailed examination of its origin and present scope.

When the dissensions in Spain foreshadowed a possible dissolution of the Spanish Empire, and even prior to the revolt of the Spanish colonies on the American 
continent, a natural apprehension prevailed in the United States that the colonies might be coveted by the rival ampires, the French or the British. Particularly was this fear directed toward the fate of Cuba and Mexico, in closest proximity. In 1808 , Thomas Jefferson, then President, the merits of whose practical statesmanship and liberal philosophy the passing of time has but enhanced, wrote to the governor of the Territory of Orleans :

"We shall be satisfied to see Cuba and Mexico remain in their present dependence; but very unwilling to see them in that of either France or England, politically or commercially. We consider their interests and ours as the same, and the object of both must be to exclude all European influence from this hemisphere."

In 1820, when the independence of the Latin American colonies had been substantially achieved, Jefferson spoke of "the advantages of a cordial fraternization among all the American nations, and the importance of their coalescing in an American system of policy totally, independent of and unconnected with that of Europe."

The occasion of the Monroe Doctrine was the threat of the Holy Alliance to assist Spain to recover her American colonies, and the effort of Russia to extend her northwestern boundary in America. The Holy Alliance, formed by Russia, Prussia and Austria to express in solemn chastizement, under the name of the "League of Peace" the horror of God and King against such blasphemies upon law and order as the French Revolution and any other revolution, had commissioned France, which had adhered to the Alliance, to restore the Spanish crown to Ferdinand, from which the people of Spain had but lately relieved him. Canning, the British Secretary of State for Foreign Affairs, having been notified by France that her successful mission in Spain had induced her to consider obedience to the call of duty by proceeding to restore the Spanish crown in America, and realizing that the restoration of Spanish authority or 
the substitution of France would, by renewal of the then customary colonial trade and navigation monopoly, seriously injure the growing commerce of England with the new Spanish-American states, approached Richard Rush, American Minister in London, as to the possibilities of a joint declaration by the two nations against the intervention of the Allies in Spanish America. Reputable historians have stated that, aside from the fear of French aggrandizement and the loss of British trade, another dominant motive with Canning was the realization that the opening of hostilities between the Allies and the South American states would cause a declaration of commercial non-intercourse between those states and Europe, which would but redound to the advantage of the United States. The British Cabinet had, in fact, already decided that they would not permit France to engage in the heroic yet not altogether disinterested mission she contemplated; but hoped that British action to that end might become unnecessary by the United States and Great Britain assuming an identical position discouraging French plans.

The United States had already recognized the independence of most of the Spanish-American states, when Mr. Rush's correspondence with Canning and his request for instructions reached the United States, in the fall of I823. A profound impression was created. Never was a declaration of policy more deliberately formulated, nor better counsel sought. The correspondence was sent by President Monroe to Jefferson and Madison for an expression of their judgment, and John Quincy Adams, then Secretary of State, submitted it to other leading public men of the country. It was on this occasion that Jefferson made his famous statement that while independence made us a nation, this proposed declaration "sets our compass and points the course which we are to steer through the ocean of time opening on us. Our first fundamental maxim should be, never to entangle ourselves in the broils of Europe; and our second, never to 
suffer Europe to intermeddle in cis-Atlantic affairs." Jefferson, Madison and Monroe, feeling that the declaration sought confirmed these aims, were in favor of making the joint proclamation suggested by Canning. Adams, however, opposed it. $\mathrm{He}$ entertained a suspicion that England's request for a joint pledge that "we could not see any portion of (the former Spanish colonies) transferred to any other power (than Spain) with indifference," was directed equally as much against the interference of the United States as against that of the Holy Alliance. In his Memoirs, Adams says: "By joining with her, therefore, in her proposed declaration, we give her a substantial and perhaps inconvenient pledge against ourselves, and really obtain nothing in return."

The formal answer to Canning's suggestion and to the plan of the Holy Alliance, which also served notice on Russia, was contained in President Monroe's Message to Congress of December 2, I823. The policy then announced, which has come to be known as the Monroe Doctrine, was substantially formulated by Adams. Its principal sections read as follows:

"The occasion has been judged proper for asserting as a principle in which the rights and interests of the United States are involved, that the American continents, by the free and independent condition which they have assumed and maintain, are henceforth not to be considered as subjects for future colonization by any European Powers. . . The citizens of the United States cherish sentiments the most friendly in favor of the liberty and happiness of their fellow-men on that side of the Atlantic. In the war of the European Powers in matters relating to themselves we have never taken any part, nor does it comport with our policy so to do. It is only when our rights are invaded or seriously menaced that we resent injuries or make preparation for our defence. . . The political system of the allied powers is essentially different in this respect from that of America. . . And to the defence of our own, which has been achieved by the loss of so 
much blood and treasure, and matured by the wisdom of their most enlightened citizens, and under which we have enjoyed unexampled felicity, this whole nation is devoted. We owe it, therefore, to candor, and to the amicable relations existing between the United States and those Powers, to declare that we should consider any attempt on their part to extend their system to any portion of this hemisphere as dangerous to our peace and safety.

"With the existing colonies or dependencies of any European power we have not interfered and shall not interfere. But with the governments who have declared their independence and maintained it, and whose independence we have, on great consideration and just principles, acknowledged, we could not view any interposition for the purpose of oppressing them, or controlling in any other manner their destiny, by any European power, in any other light than as the manifestation of an unfriendly disposition toward the United States.

"Our policy in regard to Europe, which was adopted at an early state of the wars which have so long agitated that quarter of the globe, nevertheless remains the same, which is, not to interfere in the internal concerns of any of its Powers; to consider the government de facto as the legitimate government for us; to cultivate friendly relations with it, and to preserve those relations by a frank, firm, and manly policy, meeting, in all instances, the just claims of every Power, submitting to injuries from none. But in regard to these continents, circumstances are eminently and conspicuously different. It is impossible that the allied Powers should extend their political system to any portion of either continent without endangering our peace and happiness. . . It is equally impossible, therefore, that we should behold such interposition, in any form, with indifference."

The declaration made a deep impression throughout the civilized world. In Latin-America it was hailed as a guaranty of independence and of a republican form of government. In Europe, it served to terminate the re- 
actionary activities of the Holy Alliance and stimulated the growing movement for political liberty and constitutional government.

The doctrine was by no means an altruistic statement of principle. Although expressing high moral tenets of liberal thought, it is inspired essentially by the motive of self-preservation and rests upon self-interest. That interest was deemed to be threatened by any further colonization of European powers on this continent or the control or acquisition by them of any additional American territory. Canning, although he had invited it, pronounced the Doctrine "very extraordinary" and reserved Great Britain's full privilege to colonize any unappropriated portions of America. Curiously, although the Doctrine, as a unilateral declaration of policy and notice to the world that certain acts done by foreign countries outside the borders of the United States would be deemed an affront by us, could probably not, until recent years, have been maintained without the support of Great Britain, it has been most frequently challenged by that very. power.

\section{IV.}

\section{INTERPRETATION OF THE MONROE DOCTRINE}

It will have been observed that the Monroe Doctrine sums up and reiterates in striking language the cardinal principles of American foreign policy-non-intervention, neutrality, recognition. Non-intervention, based on the separation of the two hemispheres, was to be reciprocal. Our neutrality in European quarrels was to be preserved. Recognition was to depend upon an objective standard, the de facto nature of the government in power.

With existing possessions of European countries in America the Doctrine was not designed to interfere. But the extension of their "political system" to America was inhibited. It has been asserted that with the termination of absolute monarchy in Europe, the form of government 
of the members of the Holy Alliance, the raison d'etre of the Monroe Doctrine has been lost. But this is hardly true. It is directed not merely against particular obnoxious forms of government, but against the European political system, by which was meant the groupings, associations and collective policy of European governments. Any effort to bring an American nation within the sphere of those groupings and thereby exercise European political influence in the Americas in new areas would doubtless be deemed an infringement of the Monroe Doctrine. The League of Nations has not yet seriously raised that question; but its attempted intercession between Costa Rica and Panama in their present dispute aroused some resentment in the United States.

Under an accepted definition of the Doctrine, first pronounced by President Polk in I848 in relation to Yucatan, a Latin-American state could not even with its own consent come under the domination of a European power. This went much beyond the declaration of Monroe, who expressly asserted the privilege of American states, whose independence had been acknowledged, to dispose of themselves as they saw fit. In 1870, after San Domingo had invited and then rejected control by Spain, President Grant declared: "No European power can acquire by any means-war, colonization, or annexation-even when the annexed people demands it, any portion of American territory."

Even in uninhabited territories, non-American control in effect is inhibited. Clay, Van Buren, Webster, Polk and Grant contested the power of any European country to transfer any of its American possessions to another European power; the exceptional transfer of the Island of St. Barthelemy by Sweden to France in 1877 hardly impairs the rigorous application of this rule. President Grant in his Annual Message of 1870 anticipated the complete withdrawal of European countries from America. He said: "The time is not probably far distant 
when, in the natural course of events, the European political connection with this continent will cease," and his Secretary of State, Hamilton Fish, remarked, in an accompanying report, that the policy announced by Monroe "looks hopefully to the time when, by the voluntary. departure of European governments from this continent and the adjacent islands, America shall be wholly American."

The exuberance of expression which is occasionally excited in the American by the uninterrupted and successful exercise of power is not better illustrated than by the bold statement of Secretary of State Olney, usually considered a quite conservative man, at the time of the Venezuelan boundary controversy with Great Britain. He then said: "Today the United States is practically sovereign on this continent and its fiat is law on this continent upon the subjects to which it confines its interposition." John Bassett Moore, in commenting upon this expansive assertion, says :

"Surely it must be admitted that no declaration more imperialistic was ever made by an American statesman; nor is its imperialistic lustre dimmed by the explanation, which Mr. Olney proceeds to make, that this paramount position of the United States on the American continent is due not simply to its high character, or to the fact that wisdom and justice and equity are its invariable characteristics, but also to the circumstance that its infinite resources combined with its isolated position render it master of the situation and practically invulnerable as against any or all other powers! Incidentally, it was this Venezuelan issue which persuaded Admiral Mahan to say that he had changed his mind concerning the inconceivability of war with Great Britain."

A more recent extension of the Monroe Doctrine was undertaken by President Roosevelt in 1907 in assuming control of Santo Domingo when foreign powers were pressing for payment of their claims and threatening the 
seizure of custom houses. The United States, by treaty, under what Roosevelt considered the responsibilities of the Monroe Doctrine, assumed fiscal administration of Santo Domingo and has since extended, for somewhat the same causes, an even greater degree of control over Haiti. Indeed, Santo Domingo itself has since come under police and fiscal control. The United States now exercises a quasi-protectorate over Nicargua and Panama. We own Porto Rico and some other islands. In Cuba and several other of the above mentioned states supervision of their debt limits and the reserved privilege of intervention for the maintenance of civil government serve to extend American control over a considerable portion of the Caribbean. But it can, I think, be fairly asserted that, aside from occasional unauthorized transgressions of resident officials, who thereby do this country grave harm, we have not abused our position in the Caribbean countries, and our imperialism, if such it be, has not been of an unduly exploiting type. Whatever reserved control we exercise, the largest possible measure of self government should accompany these administrations.

Our expansion southward has given rise to some fears on the part of Latin-American countries of an all-absorbing appetite of the United States for additional territory. It has brought forth bitter criticisms of our interpretation of the Monroe Doctrine, under which, while insisting upon European abstention from any control in the Latin-American states, we decline to consider the Doctrine as a self-denying ordinance upon ourselves. The only answer to this criticism is that the United States has not exhibited in recent years any serious intention permanently to acquire additional territory in Latin America, and that, in view of our preponderance of power, the Cuban enterprise manifests a certain national self-restraint. Intervention in Mexico would probably be unpopular among the American people, and 
if accompanied by any territorial accessions, might be considered by most nations as a moral stultification of our professions in the recent war. Only the moderation and general acceptability of our conduct will obtain acquiescence in our enterprise from foreign countries, and "a decent respect for the opinion of mankind" will be found ultimately as essential to nations as to individuals.

\section{V}

FOREIGN VIEWS ON THE MONROE DOCTRINE

It may be asked how such a frankly egotistical and occasionally arrogant assertion of policy as the Monroe Doctrine has received acceptance by the world. Bismarck called it an "international impertinence." European writers and statesmen have never tired of denying that it is a principle of international law. I do not believe the United States has made this claim. But without taking such a position it must not be overlooked that the assertion of jurisdiction and long-continued acquiescence therein by others is known to establish a good title both in private and public law. Contrary to President Wilson's recent statement that the acceptance of the Monroe Doctrine as a "regional understanding," whatever that may mean, constitutes the first recognition by Europe of the Monroe Doctrine, it may be said that in I903 the Duke of Devonshire declared, "Great Britain accepts the Monroe Doctrine unreservedly,". and that is probably the official view, in deed if not in word, of all the European countries.

Ultimately, of course, its validity rests upon our might and power to enforce it. But that is not its only justification; it is an expression of one of the most elemental conditions and principles of international relations, the balance of power. Few persons realize the pervasiveness of this principle in human relations, for it operates with as unerring a precision, though sometimes only vaguely 
perceptible, as a law of nature. In Europe, with its compact groups of enemy nations, the balance of power, rooted in the sense of insecurity, seemed to present the only hope of occasional periods of peace. In the division of our free and slave states before the Civil War, we acknowledged, unconsciously perhaps, the operation of the principle. The Monroe Doctrine expressed an American balance against Europe, in the maintenance of an international equilibrium. Should Asia become powerful, it may require revision. Its maintenance has doubtless been aided by European quarrels - it was this which enabled Seward to spoil Maximilian's Mexican adventure in I866-and by the fact that an American enterprise could hardly have been risked by a European power in the face of the delicate position of European relations in the nineteenth century.

Our acquisition of the Philippines has been said to weaken the Doctrine, but, after all, that assumption rests upon the acquiescence of the United States. However, much that enterprise may have trangressed Washington's precept and whatever consequences it may still have, the Monroe Doctrine is flexible enough to accommodate slight variants, even if we admit this to be one. The Lodge Resolution of 1912, though not approved by President Taft, which looked to inhibiting the acquisition by any foreign power of any harbor or place on the American continent that might threaten the safety of the United States-Japan was then primarily intended-is an expression not necessarily of the Monroe Doctrine, but as Senator Lodge said, of the fundamental principle of self-preservation upon which that Doctrine rests. Experience has established, that the Monroe Doctrine does not estop us from participating in the affairs of Asia, although it seems equally clear that it is deemed by us efficacious to keep any control by Asiatic powers out of America.

The lesson to be drawn from this portrayal of the ex- 
pansive capacity of the Monroe Doctrine is that a certain tolerance in international relations is necessary. It is one of the most elementary of human weaknesses to identify your own cause and interest with the principles of right and justice, and to believe that your own motives are higher and purer than those of others. Probably nothing has caused more distress and suffering than the reciprocal action of nations upon these assumptions. For although it seems axiomatic that no one can fairly be party and judge at the same time, the international legal system is so constituted that it authorizes each nation to be the judge of its own cause and to act upon its own conclusions in its own way. International law then legalizes the physical consequences.

The same growth in power and function that we have seen in the Monroe Doctrine is evidenced in the attitude of the United States toward an interoceanic canal in Central America. When Senator Clayton-upon whose ineptitude as Secretary of State in signing the ClaytonBulwer Treaty of 1850 Stephen Douglas partly built his reputation as an orator-declared in the Senate that the United States had no power to build a canal outside the United States, he was not contradicted. Yet after the Civil War, which galvanized the power of the central government into an effectiveness then undreamed of, few people questioned the propriety of an American-built canal under exclusive American control. When finally President Roosevelt collaborated in the establishment of the Republic of Panama, acquiring in partial compensation a strip of territory for canal purposes, the act was acclaimed as a providential recognition of the mission and destiny of the American people. A treaty with Colombia, now pending, is designed to assuage injured feelings.

To those who believe that the mission of the United States is guided by Providence the rapid expansion of our territory would seem to lend some support. In any 
event, the acquisition of new territories seemed soon to be accepted as the natural order of things, for it catered to and nourished that sentiment of nationality which in each decade had been growing stronger. Mr. Moore says that "the acquisition of new territory had become a habit with us." Indeed, had it not been for the slavery question, it is probable that there would have been little opposition to the Mexican War. Moral justifications are rarely hard to find, and the doctrine of "natural frontiers," so prevalent in Europe, has been no stranger to us.

But there is hardly any doubt that we owe to good fortune much of our present territory, notably that which we first acquired, and therein our influence on international relations proved exceedingly profitable. We became a nation just when two large colonial empires, France and Spain, had by continual wars so weakened themselves that the conservation of their resources required them to draw in their lines. Our successful war against Great Britain had given us, besides a considerable territory, neighbors who were troublesome and at best uncongenial. Every war in Europe was reflected on our borders, and affected us. In the treaty of 1778 with France, Franklin had sagaciously stipulated against the acquisition by France of any territory in North America, except in the West Indies. To any other British territory, we were to be the sole heirs. The Mississippi controversy with Spain and frequent boundary disputes made it seem desirable to acquire the Louisiana territory. Spain had transferred this to France in 1800 ; but the growing commitments of $\mathrm{Na}$ poleon in Europe made him as anxious to dispose of it as we were to acquire it. In I802, for a comparatively small sum, we obtained sovereignty over an area now covered in whole or in part by fourteen states of the United States. About fifteen years later, Spain had reached a position where she was willing to cede us all that part of the Floridas which did not belong to Mexico. 
In 1836 , Texas declared her independence and in 1845 was annexed. Then came the war with Mexico and the acquisition of California and New Mexico, and the Gadsden Purchase. "Fifty-four degrees forty minutes or fight" ultimately gave us a northwestern boundary at 49 degrees without a fight. Finally, Alaska, Hawaii, Porto Rico, and the Philippines-whose acquisition was not premeditated-and numerous islands in the West Indies and in other parts of the globe, round out an empire that widely exceeds anything the founders could have dreamed of. The late Champ Clark's optimistic prophecy that Canada would some day be a part of the United States, although not original with him, made Canada so shy that she disapproved the reciprocity agreement of I9II.

The responsibilities of managing so vast an estate are possibly greater than any advantages accruing therefrom. It is the outposts of empires that have often led to collision with the conflicting interests of other nations. One can only hope that the United States will so use its power as to create universal confidence that it holds, not a prize for national exploitation, but a trusted mandate for the civilized world.

\section{VI.}

\section{LATIN AMERICA AND THE MONROE DOCTRINE}

The Monroe Doctrine did not lead to close political relations between the United States and the countries of Latin America, for diverse reasons. Among these were distance, insignificant trade, and difference in language, origin and culture. They were far nearer to Europe in all these respects than to the United States. Nevertheless, their independence had hardly been recognized before the effort was made to bring the states on the American continent into more intimate relations. In this movement, Henry Clay was a dominant figure. The idea of American solidarity probably originated with the 
great Venezuelan statesman, Bolivar, and his idea has fructified into the vigorous movement now known as Pan Americanism. Clay was actuated primarily by his devotion to the cause of liberty and felt that since the enunciation of the Monroe Doctrine the states on this continent had a common destiny. He therefore urged and obtained Congressional authority for the sending of American delegates in 1826 to the Congress of Panama, supplying them with elaborate instructions. But the delegates arrived unhappily after the adjournment of the Congress; a misfortune which seemed prophetic, for the United States was unrepresented at each of the three succeeding congresses held up to I864. The reasons are not hard to find. Slavery had been severely condemned by the southern republics - though not abolished in the then Empire of Brazil until I888-and the atmosphere for a discussion of common interests seemed under such circumstances likely to be unpropitious; in addition, the territorial advance of the United States into Mexico created a growing feeling of hostility to this country, by no means yet dissipated. But now, where it exists, it rests rather on present apprehension. The unstable conditions of many of these states, which under republican forms of constitution had enabled despotism to hold occasional sway, had not tended to make the relations more intimate.

Yet with the advent of the Civil War, and our realization that no government is immune from revolution, had come a more sympathetic view from both sides. The unsuccessful termination of France's effort to control Mexico in the sixties and of Spain to occupy the West Coast, and the effective demonstration of the guaranty of the Monroe Doctrine, served gradually to bring about better relations. Secretary of State Blaine was an important factor in this effort, and while doubtless the growth of commercial intercourse awakened a realization of the need for more wholesome diplomatic relations, the 
sentiment for solidarity did not alone depend on such material basis. Better acquaintance made North Americans realize the virtues of the Latin American culture, as well as the fact that their more progressive countries had reached a position to which an attitude of protection was utterly inappropriate. Under Blaine's initiative the first International American Conference convened in Washington in r889; it was succeeded by others at Mexico in I901, at Rio Janeiro in 1906, and at Buenos Aires in I9IO, and only the European War has prevented others. The results achieved in the form of treaties of arbitration, of naturalization, and on various commercial subjects such as patents and trade-marks, have not been negligible; but their primary result was to enable the states on this continent to discuss matters of common interest and establish the necessary contacts.

The financial difficulties occasioned by the outbreak of the war caused the calling in I9I 5 of the First PanAmerican Financial Congress, and those occasioned by its close, the calling of the second in 1920. The most noteworthy event of the first congress was the establishment of the International, now Inter-American High Commission, which is conducting the most effective work in the promotion of common interests. Already it has obtained ratification for numerous treaties, providing for the establishment of an international gold clearance fund; facilitation of the work of commercial travellers; the arbitration of commercial disputes; and for the mutual protection of patents and trade-marks. The movement to strengthen the solidarity of interests, which the building of the Panama Canal has greatly enhanced, is certain to grow ; and the dominance of the United States will be gradually tempered, as it already is beginning to be, by the growth in power of the major republics of the PanAmerican Union. 


\section{VII.}

THE MONROE DOCTRINE AND THE FAR EAST

In the Far East, the influence of the United States promises to be portentous. Long before we had acquired a single possession in the Pacific, American traders and vessels had become numerous there. The fur trade with Canton and the whaling industry proved lucrative. With the outbreak of the Civil War, however, and with the decline in the use of wooden ships for the fur trade and in the supply of whales, a marked shrinkage occurred in the Pacific enterprise of Americans. Yet the advantages of Hawaii as a trading-post and stopping place had already brought that region within the range of American interest, and, as early as I842, the President of the United States declared in a message to Congress that the United States would oppose the seizure of the islands by any foreign power. The growth of American influence in the islands, with the gradual diminution in the native population, finally brought them under American sovereignty. In Samoa we secured a coaling station in the seventies, and later obtained a protectorate over parts of the islands, shared until recently with Germany, and now with Great Britain. By the treaty of peace with Spain we acquired Guam in the Ladrones and the Philippines, and thereby became an Asiatic Power. Until Dewey's victory at Manila there was hardly an American who dreamed of ever possessing the Philippines, but with a successful people, so powerful are the urgings of "manifest destiny" that the deliberation concerning their fate was not as to whether we should "acquire" them, but as to whether we should "give them up." That event changed our naval policy, stimulated the desire for an American controlled canal at Panama and accentuated our relations with China and Japan into national problems of the first importance. President Roosevelt, prophetically perhaps, 
called this period of the world's history, "the Pacific Era" (with a capital P).

In our relations with China we have followed a course of open dealing without seeking territory or a sphere of influence, in marked contrast to the imperialist policy of European nations. From the time we forbade our citizens to participate in the opium trade, we have been looked upon with special favor in China. Although we profited by the trading concessions wrung from the Chinese rulers by the English and the French and joined those countries diplomatically, our trade with China was so insignificant that until the late eighties the American consular and diplomatic officers were engaged principally in the protection of missionaries. Until the outbreak of the Chino-Japanese War in 1894, the American people took very little interest in Chinese affairs, notwithstanding the celebrated Burlingam Treaty. But the American Minister in Peking was instrumental in bringing that war to a close, and a former American Secretary of State represented China in the peace negotiations. While we participated in putting down the Boxer Rebellion, we had not, in spite of our growing trade, acquired a single foot of Chinese territory. It was the imminence of the breakup, by partition among the European powers, of the Chinese Empire, that induced the United States to take one of its boldest steps in Asiatic diplomacy. Unable to prevent and unwilling to participate in the proposed division, Secretary of State Hay requested acceptance of the principle of the "open door" in China. With Great Britain's support, no European nation was disposed to refuse its assent, and the gesture has doubtless saved China from the fate of other weak countries in sovereign control of coveted resources.

In a sense we have made ourselves the champions of the "open door" policy, and any attack upon it seems to be construed as an attack upon the United States. This first became apparent when Russia and Japan, shortly 
after the conclusion of their war, sought to acquire control over certain cities and railroads in Manchuria. The protests of Secretaries Root and Knox against what they considered an impairment of the integrity of China and of the principle of the "open door" and equality of opportunity enunciated by Secretary Hay-notably Secretary Knox's proposal for the neutralization of the Manchurian railways-created some misgivings in Japan and brought the first serious rift into what had until then been the most friendly relations:

Subsequent large-scale enterprises in China, requiring financial aid, were conducted on the principle of joint participation by British, French, German, American, Japanese, Russian and other bankers. A sudden aversion to "dollar diplomacy" in I9I3 induced the withdrawal of the United States from the Six Power Loan to China, President Wilson stating that there should be "no entangling foreign alliance even in respect to arrangements for supervising the financial compacts of weaker governments . . . the responsibility of the United States in the Six Power Group is obnoxious to the principles upon which this government rests." But in I9I8, American participation seems no longer to have been obnoxious to those principles, for Mr. Wilson approved our joining the Four-Power consortium, committing this government to an extent unasked in 1913. The official announcement of the Department of State, published July 29, I9I8, reads in part: "The American government will be willing to aid in every way possible and to make prompt and vigorous representations and to take every possible step to ensure the execution of equitable contracts made in good faith by its citizens in foreign lands." It would not be easy to find a more complete reversal of foreign policy than is embodied in the declaration just quoted.

In contrast with the position of the United States in China, where we followerl the diplomacy of the leading 
European powers, we led, through Commodore Perry's notable enterprise in 1854 , in opening Japan to the Western World. The rise of Japan into a world power is one of the romances of the drama of history. Adopting with marvelous facility the inventions and commercial system of the western world, engaging, like their western instructors, in successful wars of expansion, the psychology and resources of the island empire now strikingly typify the "great "power." Learning much from the United States and enjoying until recent years the friendly interest of the American people, the growing commercial intercourse between the two nations had served to produce, down to 1906, an almost complete identity of interest. Apart from Japan's protest against the annexation of Hawaii, later withdrawn, and minor incidents of only passing note, the relations between the two countries until the termination of the Russo-Japanese War, in which President Roosevelt played so prominent a part, could hardly have been improved upon. Even the acquisition of the Philippines did not visibly cool these relations. But the pressure of a growing population and the successful outcome of a war with one of the great empires of the world brought changes. International relations are dynamic, not static; one of the inherent defects of the various plans for permanent peace recently formulated is that they assume a static condition.

In 1906 the growing influx of Japanese subjects into our western states created the first official signs of racial hostility. The San Francisco School Board then made a regulation which discriminated against Japanese attending school. Japan felt the situation keenly and protested on the ground that the treaty was violated. President Roosevelt seemed inclined to agree with Japan, and sent Secretary Metcalf to California to investigate; it was soon established that the school discrimination was a minor part of an organized anti-Japanese campaign. Here again was an illustration of the awkward constitu- 
tional position in which the federal government has frequently been placed by its inability to compel unwilling states to observe or enforce treaty obligations. President Roosevelt had to assume the position of a mediator between California and Japan, and finally obtained a rescinding of the school ordinance in return for a federal immigration restriction. To this the Japanese government agreed, but the extension to Japanese of the Chinese exclusion act they have sedulously opposed. A gentleman's agreement by which Japan undertakes to keep laborers from coming to the United States has worked only moderately well. Two recent statutes of California, in 1913 and in 1920, designed to bar Japanese from any interest in land, have made acute a difficult racial problem. In view of the depth of Japanese feeling against the discrimination involved in the exclusion from naturalization of Japanese subjects, whereas we admit to citizenship Africans, Turks, Arabs and the members of other nationalities considered by them inferior, and in view of the general belief that the discriminatory legislation constitutes a violation of the treaty of I9II, the moderation and self-restraint of the Japanese is to be commended. They are skillful diplomatists. How the new proposed treaty with Japan will deal with this irritating subject is, of course, still unknown.

But the real difficulty in our diplomatic relations, if such it be, arises not in California, but in China. Japan's growing population and the need for foreign markets has caused her to penetrate Manchuria, and the twentyone demands on the Chinese government in I9I 5 indicate a policy of establishing her hegemony in China. This she has endeavored to insure, notwithstanding its apparent violation of the "open door" principle, by obtaining agreements from the western powers in the nature of estoppels. Why the United States ever signed such a vague instrument as the Lansing-Ishii agreement, which is more likely to create than to allay trouble, is not 
yet known; doubtless war exigencies were responsible. Japan, significantly said Count Motono, is in a better geographical position to interpret the agreement than the United States.

We have looked with more than passive anxiety on Japan's penetration in Siberia which, though alleged to be temporary, may not be. In view of the British-Japanese alliance, and Russia's momentary collapse, we seem to have assumed the burden of keeping Japan in what we consider her place. The consequences cannot be foreseen.

More recently, Japan's efforts to assert and retain jurisdiction in Shantung, contrary to pledges formally given, have created an unfavorable impression in the United States, although, unfortunately, it is courting error or disappointment at any time to test international conduct, usually inspired by motives of national selfinterest, by the ordinary standards of morality. Japan's still more recent assertion of jurisdiction, under a League of Nations mandate, over the island of Yap, through which passes the cable connecting the United States with the Far East, brings to a close a long series of contested issues whose sober consideration by both countries does credit to their mutual sense of tolerance and forbearance. The often repeated slogan of our "mastery of the Pacific," to which Roosevelt in an ebullient moment, once gave exultant expression, is, in theory and ought to be in fact, a myth; one might suppose that the Pacific Ocean is large enough to permit both nations to exist and maintain interests there.

It will have been observed that in the Far East the principle of "non-intervention" is conspicuous by its absence.

Finally, it seems necessary, in discussing the United States as a factor in international relations, to mention the vital part played by the United States in the European War, a part which has materially affected the course 
of history. What effect this intervention will ultimately have on our own future and that of the rest of the world, only time can tell. In so far as we defended our rights as neutrals from unlawful invasion by German submarines, we followed the precedent established in 1798 and I8I2. This is the ground of war upon which the Resolution of Congress of 1917 is based, and it is the only ground which I believe will stand the test of historical criticism. In so far as President Wilson went further, seeking to dictate and participate in rearrangements of the map of Europe and to create a phantom League of Nations, ostensibly for the preservation of peace, but actually serving other purposes, he departed, doubtless, for what seemed to him good reasons, from the fundamental principles upon which the nation was founded and has since developed. Fortunately, the American people have vetoed that dangerous step, but the mere effort to withdraw from the commitments he sought to make will render exceedingly difficult the tasks of the present administration. In spite of the fact that certain idealists or moralists profess to have discovered recent changes, Europe is still Europe, the victim of its political system, with " $a$ set of primary interests, which to us have none or a very remote relation." M. d'Haussonville, a French publicist, aptly compared the nations of Europe to a party of gamblers seated around a green table grown somewhat shabby with age, where each in turn takes the bank. Viewing the distracted countries of Europe in I92 I, it seems to me that no one has expressed a more correct judgment than our own Thomas Jefferson. "Europe's political interests," said he, "are entirely distinct from ours. Their mutual jealousies, their balance of power, their complicated alliances, their forms and principles of government, are all foreign to us. They are nations of eternal war." It requires but an impartial mind to observe that the statesmen of Europe are still History will appraise their handiwork. 
In the light of the lessons of the past two years, our duty seems more plain than ever, namely, to keep as far removed as possible from their political enterprises. The warning of John Adams, as a glance at the daily newspapers will confirm, might have been uttered yesterday:

"It is obvious that all the powers of Europe will be continually maneuvering with us to work us into their real or imaginary balances of power . . . but I think it ought to be our rule not to meddle; and that of all the powers of Europe, not to desire us, or perhaps, even to permit us, to interfere, if they can help it.'

But Europe today is desperate. By every method of inducement known, by appeal to our sympathy, generosity, apprehension, gratitude, cupidity, she is seeking to persuade us to liquidate the consequences of her unfortunate system of conducting international relations. I cannot blame her; it is the instinct of self-preservation that speaks. But while we cannot, in view of our own vital interest in the restoration of Euorpe, assume that indifference which the Swedish Ambassador in London suggested to John Adams in I782: "Sir," said he, "I take it for granted, that you will have sense enough to see us in Europe cut each other's throats with a philosophical tranquillity"; nevertheless, it would be a mark of national immaturity to disregard Washington's injunction against passionate attachments for some nations and inveterate antipathies to others. Our safety and our self-respect lie in the cultivation of the Jeffersonian precept of "honest friendship with all nations, entangling alliances with none."

\section{VIII}

INDIRECT INFLUENCE OF THE UNITED STATES ON WORLD POLITICS

The advent of the United States into the family of nations was not only of immediate consequence to the 
world, in disturbing the balance of power in Europe, but it also exercised an indirect influence, the fruits of which have left a permanent impress on international relations.

Mention has been made of the circumstances, physical and ideal, which dictated the principles espoused by the nation then in embryo-the distance from Europe, the insistence upon freedom from the European political system and its perpetual quarrels and upon emancipation from Europe's monarchical and ecclesiastical theories of government, the demand for freedom from the system of colonial, commercial and navigation monoplies. These facts and aspirations, together with the facts that independence found us with a weak government, an immense territory, a small population, a growing maritime commerce, hostile neighbors in Europe and on the American continent, who were less interested in the permanence of our existence or institutions than they were in the use which they could make of us in their political conflictspresented at once problems which tested to the full the mettle of our early statesmen. The factors and conditions with which they thus had to deal gave birth not only to the major principles of our life as a nation, which were outlined in the previous lecture, but also served to shape those collateral policies and politico-legal doctrines which mark the history of our international relations. How far these policies and doctrines have exerted universal influence may be a matter of opinion; but it can hardly be doubted that many of these principles, policies and doctrines have been powerful factors in the history of the last century and a half.

It is probably correct to say that the discovery and occupation of the new continent of America is the most important fact in modern history. It disturbed vitally the conventional groupings of Europe. In the two hundred years before the American Revolution, Spain, Holland, France and England,-rivals for American domination,--had experienced all the vicissitudes of success 
and defeat in a series of wars which from time to time changed the boundary lines of the unexplored continent and impressed England with the great lesson that the possession of sea power is the primary source of international strength and influence.

The rivalry of the European nations aided greatly in securing admission for the United States into the family of nations, for France, Holland and Spain found therein an opportunity to gratify historic grudges against England. Whether the governments that thus in varying degree welcomed us had no occasion for regret may be doubted; for the independence of a colony in America could not leave Spain unaffected, and the French monarchy always believed, doubtless correctly, that the inspiration of the French revolution was found in America. The United States, therefore, grew to nationhood, not merely by virtue of its inherent strength, but by reason of the mutual distrust and conflicts among the principal powers in Europe. The statesmen of that day knew how to seize and employ the opportunities afforded by existing conditions; and it is to their foresightedness in evaluating and estimating these conditions that our successful adolescence is primarily due. For the policies of this government down to 1820 were fashioned and developed out of the political conditions prevailing among the states of Europe.

The birth of a new nation in Europe has, as r. rule, little effect on international law or relations; the rules of its conduct are prescribed for it either by usage or by the particular group that sponsors its birth. In the case of the United States it was different. The child of a new philosophy of government, at a distance of thousands of miles from the established countries of the world, with a determination to remain free from that European system which had made the colonists sometimes the cause and always the victims of the European struggles for political and commercial supremacy, the new nation had both 
necessities and opportunities for developing new theories and practices in international relations. It is for these reasons, primarily, that the entrance of the United States into the family of nations has been deemed epochmaking.

This originality of policy is evidenced not only in the major principle of non-intervention, which gave rise to its corollary, the Monroe Doctrine, and to its natural derivatives, the system of neutrality and the doctrine of recognition of governments de facto, but it is reflected in the provisions of our earliest treaties with foreign powers, in which we find stipulations for liberty of conscience, the removal of important disabilities from aliens, mitigation of the rigor and evils of war, such as humane treatment for prisoners of war, the privileged withdrawal and departure of alien enemies and the immunity of their private property from seizure, restrictions on the belligerent privilege of visit and search, prohibition, under pain of treatment as a pirate, of the acceptance of privateering commissions by citizens of either country from an enemy of the other, and various limitations on belligerent captures at sea, including, in the treaty with Russia the reciprocal immunity of merchant ships in case of war between the signatories. Practically all these innovations were proposed by the American negotiator; they reflect a freedom from tradition and an initiative dictated in part by necessity, in part by opportunity; but their substantial merit, not only in promotion of our own interest but also in that of the world at large, is indicated by the fact that many of those provisions have long since been accepted among the most settled of the rules of international law.

NEUTRALITY

Not long after the Constitution of the United States had made us a nation capable of assuming and carrying 
out international obligations, the French Revolution broke out. The reaction of the governments of the world was much like that now entertained toward the Russian Revolution. The event, as the Revolution grew in intensity and violence, presented to the new American government its first great problem in foreign affairs, and the solution adopted marked the future course of national policy.

As the Revolution could not be promptly suppressed, some of the European governments felt it necessary to intervene, and when England's entrance into the conflict in I793 made it a maritime war, the American government had to make its great decision. The result but reveals the high calibre of men who then governed the country.

The French Revolution had aroused mingled feelings in the United States. The people generally saw in it the counterpart and response to their own recent achievement, and enthusiastically approved it. The Government realized better the responsibilities attached to association in the French enterprise. It required statesmanship of a high order, in the face of the popular clamor for aid to France, to decline to yield the ultimate good for the immediate popular demand; the leaders of that day were not sounding boards who took their position on public questions and their views of public policy from the morning newspapers. To quote John Bassett Moore:

"They understood that the peaceful demonstration of the beneficence of their principles, in producing order, prosperity, and contentment at home, was likely to accomplish far more for the cause of liberty than an armed propagandism, which perchance might ultimately degenerate into military despotism."

The country was then still weak. Yet American ships of trade were to be found in all the seas. A false step, inviting another war, might have terminated the life of the young nation. Prudence and patriotism therefore 
dictated a passive attitude toward the French Revolution. Circumstances, however, soon made more positive action necessary. England came into the war in I 793. Citizen Genet was sent to the United States by France and conducted a triumphal tour from Charleston to Philadelphia, enlisting popular support for his cause, and actually commissioning individuals and privateers for service against England. He also adopted a measure, since often imitated, of talking to a people over the heads of their government, with results as disastrous to his cause as the effort was impolitic. It usually is. To prevent acts of the people which might precipitate unhappy commitments, and to put a stop to the fomentation of hostile enterprises on American soil, which Genet, claiming authority from the treaty with France and the friendly sentiments of the people, was then sedulously engaged in promoting, Washington and his cabinet determined to issue a proclamation of neutrality. They hastened in this course for fear that hesitation might result in their being made a tool by either France or England, the principal belligerents. Washington's personal policy became the national policy. In March, I793, he wrote to Jefferson, then Secretary of State: "War having actually commenced between France and Great Britain, it behooves the Government of this country to use every means in its power to prevent the citizens thereof from embroiling us with either of those powers, by endeavoring to maintain a strict neutrality." The remark of Oswald, British negotiator of the Treaty of I783, to John Adams, had not been lost on the Cabinet: "You are afraid," said Mr. Oswald, "of being made the tools of the powers of Europe." "Indeed I am," said Adams. "What pozvers?" said Oswald. "All of them," answered Adams.

The proclamation of neutrality was published before Genet reached Philadelphia. The disputes arising out of Genet's efforts to move the Government from the course it had adopted, and to violate the principles of neutrality 
by fitting out privateers, and capturing and condemning British vessels within American jurisdiction, merely confirmed the wisdom of the American policy. The claims of Genet to employ American soil for hostile acts in favor of France against its enemies gave shape to the principles of neutrality enunciated by Jefferson, then Secretary of State. Neutrality consisted of certain rights and duties, founded primarily on the sovereignty of every nation within its own territory and its obligation of impartiality between the belligerents. Mr. Moore has summarized Jefferson's principles as follows:

"As it was the right of every nation to prohibit acts of sovereignty from being exercised by any other within its limits, so it was, he declared, the duty of a neutral nation to prohibit such as would injure one of the warring powers. Hence, 'no succor should be given to either, unless stipulated by treaty, in men, arms, or anything else, directly serving for war.' The raising of troops and the granting of military commissions were, besides, sovereign rights, which, as they pertained exclusively to the nation itself, could not be exercised within its territory by a foreign power, without its consent; and if the United States had 'a right to refuse permission to arm vessels and raise men' within its ports and territories, it was 'bound by the laws of neutrality to exercise that right, and to prohibit such armaments and enlistments.'

The neutrality proclamation of April 22, I793, was epoch-making, for it fixed what seemed until recent times the immutable policy of the United States toward European wars. It did not use the word "neutrality," for Jefferson believed that an avowal of permanent neutrality should not be bartered away without concessions from the belligerents. The proclamation was actually drafted by Randolph, Attorney General, and announced that "the duty and interest of the United States require that they should with sincerity and good faith adopt and pursue a conduct friendly and impartial toward the belligerent powers." Citizens were warned against joining in the 
hostilities, that they carried contraband at their risk alone, and that violations of the law of nations within American jurisdiction would be punished.

The proclamation created a profound impression in Europe; for it was at least novel that a people which had theretofore been involved in practically every European war to which England, France or Spain had been parties should now assert their complete independence of European quarrels. It was a logical step in the policy of nonintervention in European affairs, to which utterance had already been given by some of the leaders of the government, and foreshadowed Washington's Farewell Address, which definitely made non-intervention a cornerstone of American foreign policy.

The enforcement of our neutrality in the face of the activities of Genet, much popular disapproval, and the weakness of the federal power, was not always easy. But a notable charge to a grand jury by John Jay, the first Chief Justice of the United States, in May, I793, ranks among the highest expressions of American policy and has been honored by its substantial incorporation in $187 \mathrm{I}$ in the Treaty of Washington with Great Britain, another notable step in the evolution of the law of neutrality. Jay said:

"The laws of nations make part of the laws of this and of every other civilized nation. They consist of those rules for regulating the conduct of nations toward each other which, resulting from right reason, receive their obligations from that principle and from general assent and practice. To this head also belong those rules or laws which, by agreement, become established between nations. . We are now a nation, and it equally becomes us to perform our duties and to assert our rights. . The United States are in a state of neutrality relating to all powers at war. Therefore they who commit, aid, or abet hostilities against those powers, or either of them, offend against the laws of the United States, and ought to be punished." 
Between the open violation of our neutrality by Genet and his adherents in the United States at home, and the like disregard of our neutral rights at sea by both France and England, the course of the government was difficult. Nor were we fortunate in some of our diplomatic appointments to France. Gouverneur Morris, first sent by Washington, was too cold toward the Revolution for French taste, and his successor, James Monroe, too warm for American neutrality.

In view of the vagueness as to what were at that time neutral rights and privileges, it is not surprising that the budding commerce of America paid a heavy price for the prevailing uncertainty and the unwillingness of each of the belligerents to permit American vessels to trade with the other except under severe restrictions. There was no agreement as to what constituted contraband or blockade. Between paper blockades and the unlimited extension of contraband lists, the fate of the neutral's trade seemed precarious. The rule that enemy goods, not contraband, on a neutral ship, were exempt from seizure, enunciated by Frederick the Great under the name "free ships, free goods" and embodied in the Armed Neutrality of 1780 and in the treaty concluded by Benjamin Franklin with Prussia in $\mathbf{1 7 8 5}$, was still far from receiving general acceptance; its ultimate persistence and inclusion in the rules of international law are in no small degree due to American effort.

The insistence upon our rights furnished a critical test for our diplomacy, and the principles adopted in the Jay treaty of 1794 with England and the arbitrations for which it provided constituted a marked advance in the development of international maritime law. The concessions gained therein for neutrals were much aided by the recognition of the obligations of neutrals. which had been embodied in the proclamation of 1793 and the statute of I794 which carried those obligations into effect. In substance, the Act of 1794 forbade within the United 
States the acceptance of commissions, the enlistment of men, the fitting out and arming of vessels and the setting on foot of military expeditions in the service of any government or people against a government with which the United States was at peace. Compensation was provided for in the Jay Treaty for those British subjects who had suffered damages from our failure to prevent French privateers from violating our neutrality, a precedent from which we reaped great advantage some eighty years later in the settlement of the "Alabama" claims of American citizens against Great Britain. Hall, the well-known English authority on international law, says of the attitude of Washington's administration:

"The policy of the United States in 1793 constitutes an epoch in the development of the usages of neutrality. There can be no doubt that it was intended and believed to give effect to the obligations then incumbent upon neutrals. But it represented by far the most advanced existing opinions as to what those obligations were, and in some points it even went further than authoritative international custom has up to the present time advanced. In the main, however, it is identical with the standard of conduct which is now adopted by the community of nations."

Not long after the proclamation of neutrality of 1793 began that reciprocal retaliatory promulgation of Orders in Council and decrees by the English and French governments which made neutral commerce subservient to belligerent expediency. Only the difficulty of determining which belligerent was doing us the most injury, our military weakness and the realization that participation in the war would be more disastrous than helpful to our commerce, persuaded the statesmen of that day to overlook the many provocations to war and adopt negotiation instead. Each belligerent acted, with little qualification, upon the principle asserted by Great Britain during the recent war, namely, that if one belligerent is allowed to make an attack upon the other regardless of neutral 
rights, his opponent must be allowed similar latitude in prosecuting the struggle "and is not limited to the adoption of measures precisely identical with those of his opponent." On this point, complete harmony seems to prevail among belligerents. Notwithstanding all their efforts to obtain by negotiation more favorable treatment for American commerce, the United States was, nevertheless, drawn in 1798 into the limited war with France which lasted until i8oo. The Peace of Amiens brought a brief respite to American traders and to a much harassed Department of State.

In I803, the great struggle between France and England was renewed. The reciprocal issuing of retaliatory Orders in Council and Napoleonic decrees again threatened the trade of neutral American merchants and tested the diplomatic resources of our young Department of State-this time with less success than in the preceding decade. Neutral rights were all but blotted out by the contending belligerents. Paper blockades were the order of the day. Fortunately, we were not then drawn into the war, and at least we were able by continued protest to keep alive the claims of neutrals, which ultimately, long after the war, did obtain recognition.

Embargoes and non-intercourse proving weak as the weapons of a neutral, we were finally, through the complication with the question of impressment, drawn into the war of 1812 with Great Britain. From France we obtained a large indemnity by treaty.

Until the time when we became involved in the recent European War the United States had been the consistent champion of neutrality, and had maintained its principles through the most difficult period of its history. It had the satisfaction of seeing its recodified Neutrality Act of I818 adopted substantially by Great Britain in the Foreign Enlistment Act of I8I9. It saw the main contentions of its early days adopted as law in the Declaration of Paris of 1856 and later observed-namely, that the 
neutral flag covers enemy's goods, except contraband ; that neutral goods, except contraband, are free from capture on an enemy ship, and that legal blockades must be "effective". It made important contributions to the rules of neutrality adopted by the first and second Hague Conferences and the London Conference of I908. How far these rules have been qualified by violation during the late war, it is perhaps too early to say. It may, however, be observed that though the recent European War began with a proclamation of neutrality on our part, the practice of neutrality was beset with difficulties. The conditions and the motives which had prompted our declaration of neutrality in the European conflict of a century before were no longer present; and the diplomatic skill of a Washington and Jefferson was conspicuously absent. How far neutrality as a legal status, with privileges, rights and obligations, has suffered permanent injury only the future can tell; the apparent effort embodied in the Covenant of the League of Nations to make every war hereafter a universal war would seem to indicate a belief that the law of neutrality had exhausted its usefulness. I venture to differ with such an opinion. On the contrary, I believe that the task of the immediate future is to strengthen rigidly the law of neutrality by doing away with much of the difference between prohibited and permitted acts of individuals and restricting those privileges of the neutral individual in the form of loans and other aids to belligerents which ultimately make of neutrality either a mythical status, a precarious privilege, or an unwelcome and distrusted obligation.

\section{(b)}

\section{RECOGNITION}

Equally consistent with the doctrine of neutrality as a derivative from the fundamental American principle of non-intervention has been the policy governing the recog- 
nition of new governments-at least down to the beginning of the Wilson administration, when so many of the traditional principles of our foreign policy were abandoned or modified.

Recognition is not a legal right of the new government or state, nor is it altogether a matter of favor. It is a question of policy, which is influenced by such factors as historical precedent, conceptions of national tradition and interest, the desire for harmonious international, commercial and political relations, and the necessity of acknowledging facts. Nothing is more neutral, therefore, than the policy adopted by the United States in Washington's administration of recognizing new governments created by revolution. Our own national origin, our conceptions of liberty and self-government, our dissociation from the monarchical principle of legitimacy of governments, which we had but lately proved, our determination not to intervene in the political affairs of other nations, our desire to keep open the channels of commerce, our respect for practical facts rather than ancient theories-all combined to persuade the new American nation to recognize promptly any new government demonstrating its capacity to hold for a reasonable period the reins of government. De facto control was the test of government, rather than the legitimacy of the means by which it was acquired. Revolution is always unconstitutional, yet most of the states of the world, including the Great Powers, owe their existence to such unconstitutional origin. The epigram "whoever has the archives is the government" has a very practical connotation.

The French Revolution was responsible for the establishment both of our policy of neutrality and of recognition. In an instruction of Thomas Jefferson, Secretary of State, to Gouverneur Morris, Minister to France, March 12, I792, there was embodied what has since been deemed a classic expression of our national policy. 
"We surely cannot deny to any nation," said Jefferson, "that right whereon our own government is founded-that everyone may govern itself according to whatever form it pleases, and change these forms at its own will; and that it may transact its business with foreign nations through whatever organ it thinks proper, whether king, convention, assembly, committee, president, or anything else it may choose. The will of the nation is the only thing essential to be regarded."

Jefferson prescribed no particular tests by which this national will was to be ascertained, whether election or acquiescence. The mere continued existence of the new government for a reasonable length of time and its fulfillment of the functions of administration within a considerable portion of its territorial limits was presumably a sufficient demonstration of its ability to express a national will.

Down to the Civil War it had been a boast of our national tradition to be the first nation to recognize a new government that had manifested its capacity to maintain the spark of life. The precedent was laid with the revolutionary governments of France, beginning in I792, and was acted upon in South and Central America and in various countries of Europe, even with respect to new monarchies. We were among the very few governments to recognize Don Miguel as King of Portugal. Reasons for recognition rather than excuses for not recognizing de facto governments, were sought. A revolution arousing international concern was not denominated a "domestic question" of the parent state. President Pierce in his message to Congress of May I5, 1856, in explaining the reception of a new minister from Nicaragua, summed up a long line of distinguished precedents when he said:

"It is the established policy of the United States to recognize all governments without question of their source, or organization, or of the means by which the governing persons attain their power, provided there be a government de facto accepted by the people of 
the country, and with reserve only of time as to the recognition of revolutionary governments arising out of the subdivision of present states with which we are in relations of amity. We do not go behind the fact of a foreign government's exercising actual power to investigate questions of legitimacy; we do not inquire into the causes which led to a change of government. To us it is indifferent whether a successful revolution has been aided by foreign intervention or not; whether insurrection has overthrown existing governments and another has been established in its place, according to pre-existing forms, or in a manner adopted for the occasion by those whom we may find in the actual possession of power. All these matters we leave to the people and public authorities of the particular country to determine ; and their determination, whether it be by positive action or by ascertained acquiescence, is to us a sufficient warranty of the legitimacy of the new government."

The Civil War produced many changes in the spirit and the constitutional development of the United States, the effects of which cannot yet be fully established. Among the earliest and most obvious effects, however, was the change in attitude assumed toward the recognition of new governments and states. The unprecedented effort of a large section of the country to establish an independent government shook to its foundations some of our most cherished theories. Seward saw in this attempt no principle of self-determination, but a treasonable and seditious effort to subvert the constitution. He at once exerted every endeavor, by contesting the legality of the Confederate Government, to prevent foreign governments not only from recognizing its independence, but even its belligerent character. We now find the curious historical freak of Europe acting on the American theory de facto possession of power as the criterion of recognition, and Seward supporting the European theory of legality or legitimacy. The diplomatic controversy resolved itself into an issue as to the de facto existence of the Confed- 
erate government, and it was not without incurring serious dangers to our international relations that Seward was finally able to avert the recognition of the independence of the South by Great Britain and other powers.

The event was bound to exert important influence on our recognition policy. The obvious practical test of de facto authority, which had so long been a part of our tradition, could not be readopted without important qualification. Thus, we find Seward in 1866 , after our great danger of dissolution had been successfully averted, conditioning the recognition of new governments not merely on their de facto character, but on the consent of the people, evidenced either by sanction of the legislature or by a formal election. Consistently therewith, but entirely out of harmony with our national traditions, Seward refused to receive the representatives of revolutionary factions in foreign countries seeking to establish their independence.

But again conditions were found more imperious than theories. Revolutionary governments in South America which established de facto authority without formal consent of the people had to be dealt with, and we find down to I890 a partial, and after I890, a complete departure from the conditions of legitimacy which Seward, impelled by the crisis through which he had passed and the requirements of consistency, had sought to attach to our recognition of new governments. The precedent of making recognition conditional had several important effects. It served to encourage the exercise of a power. by withholding recognition-though earned by objective standards-to interfere in the domestic affairs of foreign countries, contrary to the national tradition. When thus used as a political instrument to exert our will over that of other nations, it subverts the principle of recognition and the theory of the independence of states.

As the element of express consent of the people receded in importance as a condition of recognition, it was re- 
placed by the more modern criterion of capacity of the new government to perform the international obligations of a state. Possibly this condition, applied subjectively, still enables a recognizing state to exact terms in the extension of recognition, contrary to our original theory. But while the departure of Europe from the criterion of legitimacy to that of de facto authority exerted an influence upon us, the development of imperialism, which seems difficult to dissociate from growth in economic power, militates against a disinterested attitude toward the free political development of other states. The enterprise which resulted in the recognition of Panama will illustrate my point. But this case, like that of the Wilson policy toward the Huerta government in Mexico and the Tinoco government in Costa Rica, ought to be regarded not merely as involving the question of recognition, but rather as a question of intervention, which is always a matter of political opportunism. In like case are the various extensions of recognition to the new states in central and southeastern Europe during and since the World War. They rest on expediency rather than on principle. This also accounts for the withholding of recognition from the de facto government of Russia.

President Wilson, on assuming office in March, I9I3, announced in a statement of policy toward Latin-America a new doctrine of refusal of the United States to recognize new governments which had established themselves by revolution. The object of his administration, he said, would be "to cultivate the friendship and deserve the confidence of our sister republics of Central and South America," and to promote the common interest. "Cordial understanding and co-operation between the peoples and leaders of America," he said, was possible "only when supported at every turn by the orderly processes of just government" based "not upon arbitrary or irregular force," but upon "law," upon the "consent of the governed" and upon "the public conscience and approval." 
While the President doubtless had in mind the government of General Huerta, who had incurred Mr. Wilson's violent dislike-although it so happens that he was actually the President of Mexico according to the Mexican constitution-the declaration was deemed to constitute a policy of refusal to recognize revolutionary governments. Under the guise of promoting constitutionalism, it embodies in effect a reincarnation of the discarded theory of legitimacy of the Holy Alliance, to which likewise revolution was anathema. Read in the light of the principles upon which this nation was founded, it must arouse a feeling of wonder. But from the fact that President Wilson promptly recognized recent revolutionary changes of government in Peru, Bolivia and Guatemala, in apparent disregard of his announced policy, one may conclude that the declaration has more oratorical than political importance.

While the development of the recognition policy of the United States has experienced notable qualifications, induced by the events of history and political expediency, the policy has nevertheless so uniformly reverted to type after occasional variants, that it would be safe to say that the de facto criterion of governmental authority is still practically the basis of our recognition policy. The more frequent, however, the departures from principle the more likely it is that the country will drift into the paths of opportunism, with consequent dangers ultimately to the national welfare.

FREEDOM OF THE SEAS

When the United States achieved independence, the exorbitant claims of Spain, Portugal, Great Britain, and Denmark and other similar states to sovereignty over parts of the high seas had largely been abandoned. Enlisting early, as we have seen, in the struggle to safeguard the rights of neutrals against impairment in time of mari- 
time war, the new nation also promptly challenged some of the most time-honored restrictions upon the freedom of navigating the seas in time of peace. In this, they served not only the interests of the United States, but of the entire world.

The dependence of large sections of the population of the new country upon maritime commerce made restrictions upon its free exercise at any time, and especially in time of peace, irritating, expensive and sometimes intolerable. Among the earliest American efforts to secure the freedom of navigation throughout the world was that involved in obtaining relief from the exactions of the Barbary States, Morocco, Tunis, Tripoli and Algeria. The rulers of these states had obtained the sanction of a long-continued practice to exact tribute from the vessels trading in the Mediterranean. Before the Revolution, a considerable American commerce had developed with ports in the Mediterranean. As it had to be abandoned on the outbreak of war, one of the early tasks of the peace was to restore it. It became necessary, therefore, to make terms with the rulers of the Barbary States, who had grown strong and wealthy in their tolerated occupation of licensed robbery. Yet they were but modern examples of a system which had for centuries admitted exclusive claims to jurisdiction over waterways and wide expanses of the sea.

Down to I806, Great Britain had exacted from foreign ships in the waters of the Four Seas around the British Isles evidences of formal submission to British jurisdiction; and the practice of admitting foreign ships to national ports on payment of special dues only and excluding them from colonies altogether had long been common. As products of their time, the Barbary "pirates" are not, therefore, to be too severely condemned. They had, however, adopted certain Oriental practices which made the system rather unbearable, although the states of Europe had found it cheaper to buy them off than to 
contest their claims. The rates they charged for their appeasement were changed without notice, and seem sometimes to have been based on the modern principle of what the traffic could bear; and they had the irritating habit, in addition to capturing the vessels, of throwing into slavery, subject to ransom, the seamen belonging to vessels who would not pay the price of their friendship. Their appetite grew with what it fed upon. The Dey of Algiers and the Bashaw of Tripoli, particularly, were afflicted with itching palms, which required much ointment, in various forms, to soothe. Down to 1815 , intermittent war with these pirates had temporarily interrupted the exaction of their blackmail, but no final end was made of the system until in I8I 5, Congress, at President Madison's recommendation, decided to wait upon the Dey of Algiers with sufficient force to convince that potentate of the error of his ways. The treaty which concluded that war brought to an end every exaction of tribute in any form in the Mediterranean.

One of the claims of jurisdiction upon the high seas which survived the abandonment of extensive assertions of sovereignty was that of subjecting the merchant vessels of foreign nations to visit and search by national warships, in time of peace as well as in war. An incident of this practice, in time of war, was the taking out of neutral ships of fellow-nationals of the belligerent found on board. Great Britain, during the wars between 1793 and I8I5, had thus taken out of American vessels not only British subjects, but also naturalized Americans of British origin, whose American citizenship under the prevailing doctrine of indelible allegiance, Great Britain refused to concede. This practice, proving increasingly obnoxious and harmful to American commerce, was resisted by the war of I8I2, and although not referred to in the Treaty of Ghent which brought that war to a close, the practice has not been renewed. Final evidence of its illegality is found in the American admission in I86I of 
the correctness of the British position in protesting against the forcible taking by an American warship of the Confederate commissioners, Mason and Slidell, from the British steamer "Trent".

Claims to examination of foreign merchant ships in time of peace had by the nineteenth century been reduced to the purposes of suppressing the slave trade and piracy. While the United States sympathized with the purpose, it resisted tenaciously' every effort to subject American vessels to search by foreign ships on the high seas. Doubtless the perversion of the privilege of belligerent visit and search to include impressment had something to do with this reluctance, yet only by international co-operation can such an institution as the slave trade be suppressed. In this movement Great Britain took a leading part. Although nearly every other country was willing to make treaties with England conceding a reciprocal right of search for this philanthropic purpose, it was not until I862, after many diplomatic efforts, that the United States by treaty with Great Britain admitted the right of any foreign vessel to stop an American ship at sea in time of peace, and the admission then was confined to a limited area around Africa and some of the islands in the Carribbean. The principle has since been admitted within defined zones around Africa by the Brussels Slave Trade Convention of 1890 and by a treaty of I9I I for the protection of fur seals in Bering Sea.

The protest of the United States in 1873 against the stoppage by a Spanish warship of the falsely registered American steamer "Virginius," engaged in a hostile enterprise against Spain in Cuba, illustrates the traditional insistence of the United States upon the freedom of its vessels on the high seas in time of peace from foreign interference. Pirates, of course, are excluded from this protection.

The consistent effort of the United States to free the channels of maritime commerce from artificial restrictions 
is exemplified in the leading part assumed by this country in bringing about in 1857 the relinquishment by Denmark of her claims to the exaction of tolls from vessels passing through the waters connecting the North Sea with the Baltic. The demand for opening the Straits of Magellan to free transit encountered no resistance from Chile.

A similar policy marks the diplomacy involved in securing the freedom of navigation in the Canals of Suez and Panama, though it cannot be said that unrestricted transit in the Panama Canal is assured for anything but peaceful commerce. The "neutralization" of the Canal is nominal only, since the fortifications enable the United States in time of war to use the Canal as national interests may dictate.

The policy of opening the channels of trade is similarly exemplified in the long diplomatic effort to secure the freedom of navigation in international rivers, such as the Amazon, the St. Lawrence, the La Plata and the Paraguay. This was perhaps but a reflection in America of the universal effort to secure freedom in river navigation, of which the notable instances in Europe involve the Danube and the Rhine.

The demand by contiguous states, for monopolization of fishing in the interests of their own nationals, has induced the last surviving claim of exclusive jurisdiction over wide bays and marginal seas, beyond the conventional ten miles and three mile limit. The three mile zone, incidentally, was for the first time officially adopted, in I793, by the United States. The more extended claims have now been gradually limited by treaty or acquiescence to certain definite areas, in which the geographical configuration of the land or considerations of expediency or history have justified their admission. Entire consistency on the part of the United States cannot be asserted, for while we have sedulously resisted the claims of Great Britain, Russia and other nations to the exercise of exclusive jurisdiction in wide bays or 
particular expanses of sea, we insisted, on historical grounds, upon American jurisdiction over the Bering Sea, a claim which was disallowed after arbitration.

The expression "freedom of the seas", which has been deemed an essential factor of American foreign policy, has been used in so many senses that confusion in its meaning is natural. In time of war, the freedom of using the sea is, of course, greatly, if not entirely, impaired by the belligerent exercise of the rights of capture, and the enforcement of rules as to blockade, contraband carriage, and collateral restrictions, legal or illegal, which their strength permits them to impose upon neutrals. The United States came into being at a time when war had ceased to be the normal and had become the abnormal and exceptional relation between states. They were, therefore, able to give vitality to the principles of neutrality which they had championed, some of which had already received approval by the European alliance known as the Armed Neutrality.

Except for a brief period, during the Civil War, the United States has uniformly advocated limitations upon the privilege of belligerents to interfere with maritime commerce, and corresponding enlargement of the rights of neutrals. This, of course, is consistent with its traditional policy of removing restrictions from commercial intercourse in time of peace and of war. Success in such an effort will depend, at any given time, upon the strength of the particular belligerents, so that it is hard to say how far American doctrines have secured universal acceptance. Thus, the United States in the recent war tolerated, not without protest, such practices by Great Britain as the so-called "blockade", reminiscent of the Napoleonic decrees and Orders in Council of a century ago, the blacklist, operating between neutral countries, the uncontrolled extension of contraband lists, new constructions of the doctrine of continuous voyage, the seizure of American mails at sea, nearly all in violation of 
pre-war agreements, and such practices by Germany as the establishment of war zones for unprecedented purposes and the use of submarines as commerce destroyers. These impairments of the rights of neutrals, the last of which finally persuaded us to enter the conflict, merely illustrate how mythical is the freedom of the seas in time of war.

From this recital, one may judge how great are the chances for acceptance by the stronger naval powers of a policy long advocated by the United States, and sometimes identified with the term "freedom of the seas". This is the inhibition of the capture of private enemy property at sea, ships or goods, except contraband, and except for blockade. In I 785, Franklin incorporated this provision in our treaty with Prussia and it is found in the treaty with Italy of $187 \mathrm{r}$. At various times, our Secretaries of State, including John Quincy Adams, Clay, Marcy, Fish, Hay and Root, have proposed to foreign powers this limitation upon belligerent action-President Roosevelt recommending it as a matter of "humanity and morals." A Congressional Resolution in 1904 advocated general adoption of the measure and the United States delegates at the first and second Hague Conferences were instructed to propose its consideration and approval. Dr. Scott says, in his report on the second Hague Conference, that failure to obtain approval for it "was due solely to the fact that large maritime powers such as Great Britain, Japan and Russia, and in a lesser degree France, were unwilling to renounce the right of capture of private property, either as a means of preventing a resort to arms or of shortening the wary by bringing the enemy to terms."

The experience of the recent war would seem to indicate that in a war between the great powers, not only are the rights of neutrals negligible, but that the conduct of warfare at sea is subject to fewer restraints than the conduct of war on land. It was the realization of this condition that induced the United States to enter upon its en- 
larged naval program, which some of the recent belligerents do not regard with equanimity. Instead of ameliorating the status of private property at sea, by assimilating it to the immunities heretofore enjoyed by private property on land, the Treaty of Versailles has adopted the medieval practice of confiscating private enemy property on land. So inconsistent is this measure with the modern requirements of international commercial intercourse that it seems inconceivable that capitalists anywhere could have supported it. Not only is it likely to prove universally unprofitable to leave foreign investments in this precarious position, but it reduces immeasurably any chance for the early limitation of armaments and of war, for the integrity not merely of public but of private property now depends upon success in arms.

In view of what has been said, it is easily comprehensible why Great Britain refused, after it had served its moral purpose, to accept the second of President Wilson's Fourteen Points, providing for "absolute freedom of navigation upon the seas, outside territorial waters, alike in peace and war," except as international action might prescribe.

The effort to establish the rights of neutrals and the freedom of the seas generally is but part of the larger American policy of removing so far as possible all restrictions upon the freedom of commercial intercourse. When the United States became an independent nation, the world was fettered by the most exclusive restrictions in trade and navigation. The colonial monopoly was perhaps the most prevalent. The disadvantage of the colonists in being confined, in their European trade, to dealing with Great Britain, in British vessels, had been tempered by the freedom of intercolonial trade; and that with the British West Indies had grown to considerable proportions. Having organized an independent state, American merchants were much disappointed to find themselves excluded, as foreigners, from the lucrative West Indian 
Trade, and the effort of American diplomacy was directed to securing a lifting of the ban. Not until the 'twenties, however, when the new Spanish-American republics afforded free opportunities for trade, and when the growth of the United States in commercial importance gave them a practical power of retaliation, in the establishment of an embargo against British vessels coming from a colony closed to American vessels, was effective relief obtained. A country without manufactures and exporting raw materials, the United States sought freedom of trade in foreign markets and was willing to admit foreign ships to American ports on equal terms with its own. To maintain the open door abroad, they adopted discriminating duties against incoming goods or vessels of countries discriminating against American commerce. But the basic principle of American commercial relations was reciprocity of treatment, embodied in the first commercial treaty with France of I778. A statute of 1828 , still in force, makes a standing offer for the abolition of all discriminating duties, regardless of the origin of the cargo or the carrying vessel, and its provisions have now been extended by proclamation and treaty to many countries. Thus, the United States may justly claim a prominent share in the enlightened enterprise of breaking the shackles of the system of colonial monopoly. In the development of relations with the Far East, as already observed, the policy of the "open door" in commercia! relations was steadily pursued by the United States.

Yet the United States, by considering commerce between the United States and the Philippines, Hawaii and Porto Rico as coasting trade, from which foreign vessels are excluded, except by license, seems to have revived one of the more objectionable features of the old system of colonial monopoly, though these dependencies are, of course, open to the trade of all nations.

But while navigation is now nominally free from artificial restrictions, the opportunities for engaging in it are 
by no means equal. The system by which commerce is subject to political control operates to exclude certain nations or people from trade, either altogether or in given commodities, with various parts of the world. Preferential and discriminating tariffs and tonnage dues, the effective monopolization of the resources of backward areas, the creation of spheres of influence, the artificial stimulation of national merchant fleets-as in Section 34 of the Jones Act giving a 5 per cent. tariff reduction to goods imported in American vessels, as soon as conflicting treaties are abrogated-the control of coaling and oil st?tions and of international cables, the power of monopolizing trade arising out of the investment of capital-these are but a few of the instrumentalities by which the competing commercial nations seek to secure advantages over their rivals. Much of the practice lies within the field of what would be unfair competition under any modern system of municipal law. Foreign policy is fashioned to the maintenance of supremacy in this continual struggle, and necessarily employs in its execution the forces of diplomacy and of arms. So long as the system of unregulated and ruthless commercial competition exists, international friction is hardly avoidable.

MINOR DOCTRINES, CONTRIBUTIONS AND POLICIES

In any survey of the position of the United States as a factor in the development of international relations, a place must be found for particular contributions and certain minor doctrines and policies which mark our growth as a nation. Among these mention should be made of Dr. Lieber's code for the government of the armies of the United States in the field, of the doctrine of expatriation, of the promotion of international arbitration, of the status of treaties in our constitutional system, and of noteworthy special contributions to the development of inter- 
national law. Finally, some estimate of our present position may be warranted.

Although I think it would not be quite accurate to characterize the United States necessarily as a peaceful nation, our wars, since independence, have usually been short and have not fastened on the nation the customary psychology or paraphernalia of militarism. Yet I fancy that our diplomatic correspondence with European countries for the next few decades will be less patronizing than that of the past few in deploring their adherence to what we have deemed the antiquated system of military conscription. Notwithstanding our traditional neutrality to the arts of war, the United States has made one of the most notable contributions to the regulation of the practices of war. The code of law drafted by Dr. Francis Lieber in 1862 and known as the Instructions for the Government of the Armies of the United States in the Field, General Orders No. I0o, has been the foundation for much of the subsequent codification, at Brussels in 1874 and at the Hague in 1899 and 1907, with respect to the laws of war on land. Those instructions constitute the essential basis of the existing Rules of Land Warfare adopted by the War Department and have exerted considerable influence on foreign war codes. Moreover, they were observed in practice in two wars, the Civil War and the Spanish-American War, which is more than can be said for the Brussels Declaration and the Hague Conventions, which were either unratified or qualified in practice. Considering the absence of precedents, Dr. Lieber's code represents a remarkable product of technical skill, excellent judgment, historical perspective and sound humanitarian instincts.

The true relation between the individual and the political society of which he is a member has troubled philosophers more than it has governments. Notwithstanding the liberal pronouncement of the Declaration of Independence as to the "inalienable rights" of men to "life, 
liberty and the pursuit of happiness," not only was slavery tolerated, but the courts of the United States with practical uniformity adopted the view of the English common law that no man could sever the bonds of allegiance to his country nor abjure the duties arising therefrom, without the consent of the State. But, as immigration began to increase toward the middle of the last century, notably from Ireland and Germany, and as naturalized citizens in increasing numbers visited their native countries, difficulties were presented to the Department of State in determining the effect of American naturalization in a foreign country which declined to forego the claim, military or other, arising out of native allegiance. James Buchanan, as Secretary of State and President, was the first and most vigorous of the official spokesmen for the theory that naturalization in the United States, predicated on forswearing allegiance to the native sovereign, severed completely the bond of original allegiance and substituted a new one. This not only conformed with the national ideals of liberty of the individual to choose his own way of life and obedience, but was appropriate to a country receiving large numbers of immigrants. The difficulty lay in getting foreign countries to accept our view, always a problem in international relations.

The issue came to a head shortly after the Civil War, when the Fenian troubles in Ireland took to that unhappy land some naturalized citizens of Irish origin. They were dealt with as British subjects, and the resulting popular agitation in the United States was promptly reflected in an Act of Congress, July 27, I868, which declared that the right of expatriation was "a natural and inherent right of all people, indispensable to the enjoyment of the rights of life, liberty and the pursuit of happiness," that any ruling to the contrary was "inconsistent with the fundamental principles" of the Government, and that native and naturalized citizens should receive the same protection abroad. But without the acquiescence of for- 
eign governments, it is not easy to see how we could enforce these principles in a foreign jurisdiction. A powerful aid in this direction was obtained by naturalization treaties concluded with certain powers, of which that with Germany, negotiated in 1868 by George Bancroft, with the co-operation of Bismarck, was the first. In these the subscribing countries agreed practically to recognize American naturalization, when obtained by natives of their countries as the exclusive warrant of their citizenship.

But not all countries, nor even all the principal ones, have been willing to conclude naturalization treaties with us. Some, like imperial Russia and Turkey, deny the right of expatriation absolutely, others like France and Italy and other countries adopting compulsory military service, concede it on condition only, and require the State's consent. Thus, much of our diplomatic correspondence is concerned with conflicting claims of citizenship. Moreover, not a little difficulty in obtaining adherents for our professedly liberal views is encountered by the fact that in practice we considerably qualify the "inherent right of expatriation" proclaimed in the Act of I868, by denying the privilege of naturalization, the correlative of expatriation, to Chinese, Japanese and others; by having to admit that foreign countries, exercising jurisdiction over their native citizens, returning with an American naturalization certificate, could not be compelled to give to our law precedence over their own; and by our refusal to permit an American citizen to expatriate himself in time of war. While these confessed limitations upon the freedom of expatriation weaken the principle, it does, nevertheless, represent an American aspiration which has exerted much influence on international relations.

The public declarations of the United States, from the beginning, and the practice of its governmental departments, have been noteworthy for their acceptance of the 
law of nations, which they sought to establish on a definite foundation, as the guiding principle of international relations. Their preference for legal methods is exemplified in the extent to which arbitration has been employed by them as means of settling international differences. Only Great Britain has resorted to arbitration more frequently: From the Jay treaty of I794, which provided for three different arbitrations, down to the present time, arbitrations have been held with almost every country of Europe and with many of the States of Latin America, involving most important questions, principally boundaries and pecuniary claims of every description. The record includes such delicate matters as the "Alabama" claims and the century-old dispute over the North Atlantic Coast Fisheries, settled at the Hague in I9Io.

Nearly all the Pan-American Congresses since I889 have expressed approval of the principle of arbitration, though its practical value depends on the disposition of nations actually to submit disputes. The prevailing tendency to except from the treaty obligations of arbitration, questions of vital interest, honor, etc., but indicates how cautious nations are in agreeing to the judicial method for settling their important disputes. As it is only these disputes which could normally lead to war, the reliance upon arbitration as a means of averting war, notwithstanding the notable achievements of the nineteenth century, cannot be considered strongly justified. While the United States made valuable contributions to the establishment, at the first Hague Conference, of the Permanent Court of Arbitration, to which they have resorted on several occasions, the Senate has in recent years manifested a reluctance to widen the range of questions submissible to arbitration. By reason of the Senate's insisting upon the privilege of passing on each specific claim to be submitted to arbitration under a general treaty, Mr. Moore concludes that arbitration is now more difficult than it was in the beginning, when by executive agreement or under 
a treaty, long lists of claims were submitted without supervision by the Senate.

The so-called Bryan treaties, of which some thirty have been concluded with different nations, may be useful in preventing an immediate recourse to force when there occurs a particular incident, whose facts are doubtful, creating a dispute between the contracting nations. It provides for an examination by a commission and suspension of hostile action for a year for investigation and report. The principle, though known, was not resorted to at the time of the Tampico incident with Mexico, which gave rise to the Vera Cruz expedition against Huerta. The Bryan treaties do not seem to have great efficacy with respect to continuing injuries or issues arising out of questions of conflicting principle or policy, which, after all, constitute the effective causes of hostilities.

The recent effort to establish a court in constant session at the Hague with fixed judges was promptly weakened by the Assembly of the League of Nations by removing from it the requirement for compulsory jurisdiction, practically the only advantage it possessed over the existing court established in I899, in which the judges are selected from an appointed panel of four in each country. The latter method, jurisdiction being voluntary, will, I believe, be more productive of arbitration than the recent Hague proposal.

The United States was the first modern country to adopt the principle that treaties are not binding until ratified by a branch of the legislature, and that they constitute the supreme law of the land conferring rights on private individuals cognizable in the courts. The latter principle is not yet adopted in England and most other countries. Possibly the fact that a treaty is thus regarded like a statute accounts for the frequency, not generally realized, with which the United States has violated treaties by subsequent conflicting legislation, leaving to 
diplomatic methods the adjustment of the resulting difficulty with foreign nations.

Mention should be made, also, of the peculiar American interpretation of the most-favored-nation clause, incorporated in many commercial treaties. Under the European interpretation, special privileges granted to one nation are at once and unconditionally extended to other nations having such a treaty clause with the grantor State, whereas the United States extends the same favors only on condition that such other nations satisfy the same conditions under which these privileges were originally given to the grantee State. Without such a reciprocal concession, the American view is that the second State would receive gratuitously what the grantee State obtained only upon valuable consideration. Notwithstanding the criticism of Europe, the American interpretation has been maintained and has received the carefully considered approval of the Supreme Court.

The fact that treaties are the supreme law of the land and that the law of nations is recognized by our Constitution as a part and source of municipal law, upon which the courts may draw in determining controversies, have served to give international law a legal importance in the United States which it does not possess in many other countries. Sir Henry Maine pays a high tribute to this view of the United States that international law is an integral part of the law of every member of the family of nations, without legislative adoption or formal agreement. This undoubtedly accounts for some of the remarkable state papers which have issued from our Department of State, constituting universally acknowledged authorities on the principles of international law they expound. It has also served to endow the decisions of our courts, notably of the Supreme Court, with an international importance entirely disproportionate to the case under consideration. The names of Marshall, Kent and Story will forever be identified with these judicial contributions to 
the growth of international law. It has also encouraged American publicists to give a concrete legal setting to their views, not usually found in the writings of continental authorities on international law. With these contributions the names of Kent, Wheaton, Dana, Woolsey, Field, Wharton and Moore are prominently identified. I regard John Bassett Moore, since the death of Westlake and Renault, as the greatest contemporary authority on international law and relations. Combining, as he does, technical knowledge of the highest order, a sound, critical, yet tolerant judgment of men and events, genuine nobility of character, to which sincerity is axiomatic, a profound appreciation of the principles and philosophy of American government, and a large practical experience in intimate association with our foreign relations, it seems inconceivable that any American administration, least of all the last, could afford not to profit by his wise counsel and judgment.

And now the United States is at the cross roads. While not the greatest crisis of our history, the recent World War has created problems and developed policies which may have a profound and lasting effect upon the future of the country. Fortunately, there appears now to be a disposition to return, so far as possible, to the fundamental principles upon which our national greatness has been achieved. But one cannot escape the thought that with our change in economic and political status with respect to the rest of the world, temptations to abandon principle for opportunism and expediency will continue to present themselves. I conceive that the maintenance of our position as the leading exponent of political liberty and democracy among a free people will depend upon the steadfastness with which those temptations are resisted.

EDWIN M, BORCHARD. 



\section{Appendix}





\section{A P PEN D I X}

\section{GROTIUS, SUAREZ AND DE VICTORIA}

While Dr. James Brown Scott was Solicitor for the Department of State in 1906, he took the first steps in an admirable undertaking which has since proved to be a great boon to teachers and students of International Law, the publication of the "Classics of International Law."

"Grotius," wrote Dr. Scott on November 2, 1906, "is universally considered as the founder of International Law. This, like many general statements, is true enough but likely to mislead. He was not the founder nor was he the father of the science any more than Adam Smith was the founder or father of Political Economy as a Science. . . . We look beyond Grotius and see that the international law of today is rooted in a more remote past."

From that remote past, the Carnegie Endowment for International Peace has reprinted numerous classics in excellent and convenient form for scientific study. Among the precursors of Grotius two have been recognized by the Editor-in-Chief (Dr. Scott) as of prime importance-Francis de Victoria, the Dominican, and Francis Suarez, the Jesuit.

The influence of Suarez on international law has been well discussed by Dr. Herbert Wright in the "American Journal of International Law," vol. xiv., No. 2, page 307 (April, 1920). In reviewing a new Spanish edition of Suarez, Dr. Wright says: "James Lorimer, in his "Institutes of the Law of Nations," calls attention to "the extreme injustice of the manner in which, down to our own time, it has been customary to speak of the scholastic jurists,' and a little farther on he continues: 'The fact is, that ever since the Reformation the prejudices of Pro- 
testants against Roman Catholics have been so vehement as to deprive them of the power of forming a dispassionate opinion of their works, even if they had been acquainted with them, which they rarely were.' The same author, in a footnote, gives expression to the belief "that no more valuable contribution could be made to the literature of jurisprudence at the present time than a collection and translation of the portions of these works which have reference to general jurisprudence and international law." But these statements were made nearly forty years ago, and the injustice and prejudice, on the one hand, have largely disappeared, while interest in popularizing the translations of relevant portions of the works mentioned has long since been aroused by Prof. Ernest Nys and by the "Classics of International Law" being published by the Carnegie Endowment for International Peace, under the general editorship of Dr. James Brown Scott, and now by a new series of Clasicos jurisdicos inaugurated by the publishing house of Reus with the present volume.

The selection of the Spanish Jesuit, Francisco Suarez, as the first author in the series, is a most happy one, for the echoes of his tercentenary celebration have not yet entirely died away. Attention which had hitherto been confined to a few historians of international law, such as Ward, who calls him "a writer of great perspicuity and comprehension of mind," and Hallam, who regards him as "by far the greatest man in the department of moral philosophy, whom the order of Loyola produced in this age, or perhaps in any other," ${ }^{, 3}$ was now more popularly centered upon him, and especially did his native country hasten to make tardy amends for the oblivion into which one of the purest glories of its history had been allowed to fall.

This newly aroused interest, however, should by no means be permitted to be local, for Suarez should be universally recognized as one of the truly great founders of international law, second perhaps only to the great Gro- 
tius, if indeed to him. In fact, there is little or nothing new in Grotius' general treatment of his subject; his system is fundamentally identical with the ideas outlined by Suarez." It is true that Grotius advanced far beyond all his predecessors in the detailed elaboration of his principles, but the fact nevertheless remains that "Suarez has put on record with a master's hand the existence of a necessary human society transcending the boundaries of states, the indispensableness of rules for that society, the insufficiency of reason to provide with demonstrative force all the rules required, and the right of human society to supply the deficiency by custom enforced as law, such custom being suitable to nature."' And therefore, "it is rather remarkable," as Ward notes, "that in his survey of the writers who preceded him, he (Grotius) makes no mention of Suarez, the clearest of all those who had attempted to discuss the law of nature, and the difference between it and the Law of Nations," although it is true that Grotius elsewhere recognizes in him one of the greatest theologians and a profound philosopher.

Francisco Suarez was born at Granada on January 5, I 548, not quite a year and a half after the death of that other scholastic glory of Spain, Franciscus de Victoria. In 1564 he entered the Society of Jesus at Salamanca, where he studied philosophy and theology from 1565 to I570. Ordained to the priesthood in 1572 , he taught successively and most successfully at Avila, Segovia, Valladolid, Rome (I 580-I 585), Alcala (I 585-I 592), Salamanca (I 592-I 597), and finally Coimbra (I 597-1616). He died on September 25, I6r7, but in the short space of twenty-three years (I590-I6I3), he wrote and published twelve extensive and important works on theological and philosophical questions, as well as composed seven other works published posthumously, the last as late as 1859 .

Although there is much of interest from the point of view of international law in the other works of Suarez, such as his De bello, which constitutes Disputation XIII 
of the posthumous treatise De charitate, his complete legal system is to be found in the De legibus ac Deo iegislatore, published in 1612 (five years before the author's death) at Coimbra, where he held the chair of theology in the university. The work is divided into ten books, of which only the first appears in this volume, and, as the publishers say, for the first time in Spanish. It is presumed that the other nine books are to follow. An idea of the comprehensiveness of the entire work may be gleaned from the following titles of the ten books:

Book I-On law in general, its nature, causes and effects.

Book II-On eternal law and natural law and the law of nations.

Book III-On positive human law in itself, and as it can be considered in the pure nature of man, which law is also called civil law.

Book IV-On positive canon law.

Book V-On the variety of human laws, and especially on adverse law.

Book VI-On the interpretation, cessation and mutation of laws.

Book VII-On unwritten law, which is called custom.

Book VIII-On favorable human law, or that which grants privilege.

Book IX-On the old positive divine law.

Book $\mathrm{X}$-On the new divine law.

In his discussion of Victoria's influence, the Editor-inChief of the International Law Classics writes: "The reasons for including Victoria's tractates are sufficiently set forth by Professor Nys in his introduction, and yet the general editor is unwilling to allow the volume to go to press without a tribute in passing to the broadminded and generous-hearted Dominican, justly regarded as one of the founders of International Law, and whose two 
tractates here reproduced are, as Thucydides would say, a perpetual possession to the international lawyer. Victoria's claim as a founder of the Law of Nations must unfortunately be based upon these two readings taken down by a pupil and published after his death, without the professor's revision, and in a very summary form. They are sufficient, however, to show that International Law is not a thing of our day and generation, or of The Hague Conferences, nor indeed the creation of Grotius, but that the system is almost as old as the New World."

Both Suarez and Victoria have appeared in text and translation in "The Classics of International Law."

"James Lorimer, "The Institutes of the Law of Nations" (London, 1883), Vol. 1, p. 71.

${ }^{2}$ Robert Ward, "An Enquiry Into the Foundation and History of the Law of Nations in Europe" (London, 1795), Vol. 1, p. 16.

${ }^{8} \mathrm{Henry}$ Hallam, "Introduction to the Literature of Europe in the 15th, 16th and 17th Centuries" (London, n. d.), p. 524.

"Cf. Thomas Alfred Walker, "A History of the Law of Nations" (Cambridge, 1899), Vol. I, p. 330.

${ }^{s} \mathrm{Cf}$. ibid., p. 156 .

"John Westlake, "Chapters on the Principles of International Law" (Cambridge, 1894), pp. 27-28.

'Ward, op. cit., Vol. II, p. 614.

"Hugo Grotius, Ep. 154, J. Cordesio.

'This work and relevant portions of the De Legibus will appear in text and English translation in the Classics of International Law. 



1.

(6) 1

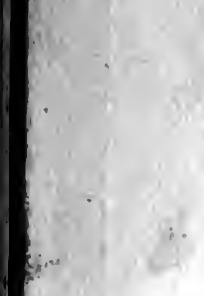





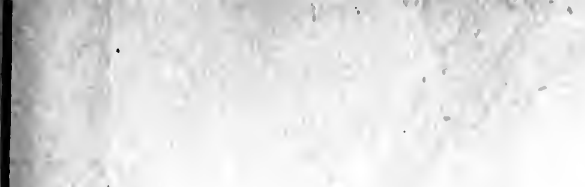




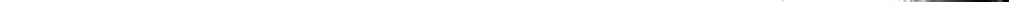




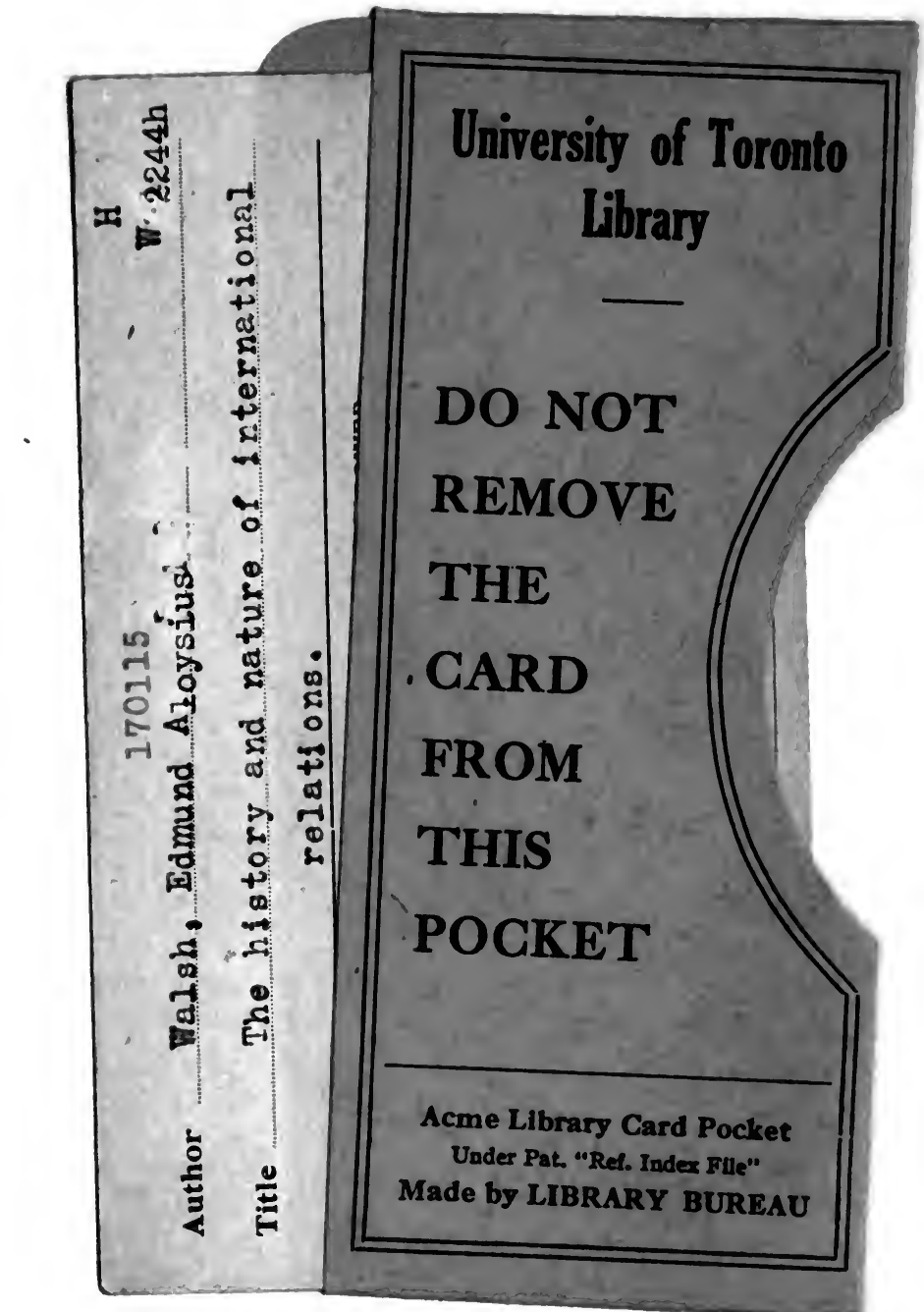


